\title{
SPIRITUALITY - A MULTIFACETED PHENOMENON
}

\author{
Interdisciplinary Explorations
}

\begin{abstract}
SUMMARY - This article reflects on the various ways spirituality is studied in academic setting. The author describes and analyses what happens in twelve disciplines: theology, religious studies, philosophy, literary sciences, history, anthropology, psychology, sociology, education, management studies, medicine, and natural sciences. The analysis follows an encyclopedic matrix: words, things, images, texts, histories, processes, relationships, professions, disciplines, and theories. On the basis of this description and analysis, the author discovered patterns of interdisciplanrity. This could be a first step for futher interdisciplinary explorations in the field of spirituality.
\end{abstract}

If we could project ourselves, for a moment, in the year 1900, looking around in the study of spirituality, we would be extremely surprised. The study of spirituality was almost completely restricted to the French catholic world. Introductions in the study of spirituality were set up from a dogmatic point of view. Outside the theology some first attempts were made to understand mysticism from a comparative or historical perspective. Psychology and psychiatry drew a clearly negative picture of mystical phenomena.

If we now return to the year 2007, the scene has completely changed. It seems as if a spiritual explosion has taken place. Spirituality became a global phenomenon, studied in various disciplines. Not only theology, the science of religion and philosophy or history and literary science, but also social sciences (anthropology, psychology, sociology, pedagogy), management studies, and even medicine and natural sciences reflect scholarly on the phenonemon 'spirituality'.

This explosion - in both lived spirituality and the scholarly reflection - is a challenge for the study of spirituality. We need reflections on the discipline of spirituality itself, its relationships with other disciplines, its theoretical foundations and its relatedness to the praxis. These need epistemological reflections. But what is epistemology? 
We consider epistemology as a branch of philosophy reflecting (1) on the structure of disciplines and their relatedness to other disciplines, (2) on the theoretical implications of disciplines, particularly the nature of knowledge; (3) on their connections with practices and professions.

1. Regarding the disciplines itself, they are part of academic institutions, with a specific history (specialisation, fusion, crossing boundaries, new inventions or developments) and forms of organisation (academies, universities, institutes, laboratories, departments, societies, journals etc.); they define their fields of research and develop their methodologies (theory building, strategies of veri- and falsification, styles of argumentation, methods and techniques, etc.); and are mostly a consortium of subdisciplines, organized in a network of reciprocal relations. These networks unfold the interdisciplinarity of a discipline: the various ways in which a discipline is interrelated with other disciplines. We know different forms of interdisciplinarity: problem based research (teamwork in medicines), crossing boundaries (performance studies), fusion (neurophysics), new inventions (computer sciences), and so forth. All these different processes move on a continuum from multidisciplinarity (experts study the same subject but each of them in terms of his own specific discipline) to interdisciplinarity (findings of various disciplines are integrated). ${ }^{1}$ Sometimes a discipline, studied separately in different disciplines, is evolving in the direction of an interdiscipline (genderstudies). Here interdisciplinarity itself is shaping the discipline.

2. Disciplines are driven by meta-disciplinary theories. Modern sciences are driven by the construction of meta-stories, postmodern approaches seem to be led by deconstruction. Some disciplines are based on a strong distinction between subject and object (empirism), whereas phenomenological research is driven by subject-implication. Idealism is more working by deductic logic, where realism stresses induction. There are 'cultural' differences between humanities and sciences. All these examples evoke the theoretical dimension permeating disciplines. Particularly important are questions about the nature of human knowledge, its limits, the validity of its claims, the relation between knowledge and belief, concepts and perception, the role of language, brain structure, socio-cultural setting, and so forth. The answers (mostly implicit) influence the epistemological processes of defining, selecting and interpreting.

3. Every discipline is, in one way or another, society driven. It is connected with practices and professions. Psychology is related with psychotherapy, sociology with its practioners, medicines with health care and pharmacy, natural sciences

J. Thompson Klein, Interdisciplinarity, Detroit 1990; Id., Crossing boundaries: Knowledge, disciplinarities and interdisciplinarities, Charlottesville 1996; J. Moran, Interdisciplinarity, New York 2002; H. Häring, Wat geen oog heeft gezien: Over zin en taak van interdisciplinair onderzoek, Nijmegen 2005. 
with techniques and industry, theology with faith communities, education with teachers and schools, and so forth. These connections are deeply embedded in the pre-scientific socio-cultural context, constantly in motion. There is a lively back-and-forth movement between non-scientific and scientific dynamics. ${ }^{2}$ Even such a decisive value as 'objectivity' is differently defined by the various traditions (empirism, positivism, logical positivism, critical rationalism, phenomenology, and so forth), under the influences of the socio-cultural dynamics and the feedback of practices and professions. ${ }^{3}$ Disciplines are intrinsically interrelated with professions and practices.

In this article, we will reflect on the various ways spirituality is studied in academic settings. We will analyse 12 disciplines: theology, religious studies, philosophy, literary science, history, anthropology, psychology, sociology, education, management studies, medicine, and natural sciences. Each of these disciplines defines the phenomenon from its own perspective and develops specific research strategies.

We will describe the adventures of spirituality within the above mentioned disciplines, according to the ten encyclopedic sections which we designed for the SPIRIN Encyclopedia ${ }^{4}$. We repeat here shortly the ten sections ${ }^{5}$.

1. Words. Within the socio-cultural context, spiritualities develop their vocabulary, in which they articulate their values, attitudes and practices, and deliver the root metaphors for scholarly reflection.

2. Things. Spiritualities organize their world, a material culture in which things get their place, supported by infrastructural arrangements.

3. Images. In the world of art and aesthetics, spiritualities create their symbolic order, mediating between the divine and human reality.

4. Texts. Spiritualities produce spiritual writings and reading procedures, providing a blueprint for spiritual hermeneutics.

5. Histories. Spiritualities unfold themselves in a variety of historical forms, each of them having its outer and inner horizon.

6. Processes. Spirituality, as a divine-human relationship, unfolds itself as a multilayered process of transformation, guided by discernment.

7. Relationships. Spirituality unfolds itself as the unity of the divine-human, interhuman, human-cosmic, and intrahuman relationships.

8. Professions. Spiritual practices, with their specific forms of accompaniment, are essentially guided by mystagogy.

A. de Waelhens, La philosophie et les expériences naturelles, The Hague 1961.

A. Smaling, Methodologische objectiviteit en kwalitatief onderzoek, Lisse 1977.

4 See for this design K. Waaijman, 'SPIRIN encyclopedia of spirituality', in: Studies in Spirituality 16 (2006), 287-326.

5 We added a new section: relationships (number 7). 
9. Disciplines. The study of spirituality, unfolding itself within different disciplines, tries to understand this process of interdisciplinarity.

10. Theories. Foundational research provides the framework by which the theoretical presuppositions and insights can be studied.

This study is focused on the process of interdisciplinarity. For that reason the dimension of 'disciplines' (section 9) is central, intrinsically connected with the dimensions of 'theories' (section 10) and 'professions' (section 8). Thus, our analysis of the twelve disciplines will start with this triad.

We will analyse the above mentioned disciplines, walking around the phenomenon of spirituality (material object), following the encyclopedic round of the ten dimensions (formal object). By doing so, we learn - hopefully - the complementarity of the different approaches and methods (interdisciplinarity). Walking around (en-kukloi-paideia), we have in mind the following 'sensitizing' questions.

- Are there signals of groundbreaking insights? Provocative ideas? Oppressed or forgotten aspects of spirituality which should be explored? Are there signs of a paradigm shift? Are the presented studies dealing with new aspects of spirituality?

- Can we observe a growing stream of publications, indicating an increasing scholarly interest? Are there overviews of new insights and developments presented?

- Has there been systematic research executed in specific areas or on specific topics? Is the research placed within a (growing) theoretical framework of systematic reflection? Can we view developments toward a coherent system of research strategies? Are there, beyond the boundaries of one discipline, forms of interdisciplinarity developed? Is integration of interdisciplinary perspectives aimed?

- Can we discover research tools, academic programs, or research institutes?

These are the 'sensitizing' questions, that sharpen our eyes, walking around the phenomenon of spirituality.

At the end of our en-kukloi-paideia we will reflect on what we learned from these encyclopedic rounds.

\section{SPIRITUALITY AND THEOLOGY}

The relationship between theology and spirituality had an eventful history. ${ }^{6}$ Before the rise of theology as a discipline, dogma, morality, bible and spirituality were

6 O. Steggink \& K. Waaijman, Spiritualiteit en mystiek: 1. Inleiding, Nijmegen 1985, 39-67;

K. Waaijman, Spirituality: Forms, foundations, methods, Leuven 2002, 369-391. 
interconnected. From the twelfth century on spirituality has been marginalized within the whole of theology, many times even excluded.

Disciplines. Towards the end of the $19^{\text {th }}$ century a process of reintegration was set in motion. Several strategies of integration are proposed: spirituality as subdivision of moral theology, spirituality deducted from dogmatics; spirituality as the centre or the umbrella of theology.7

Meanwhile, theology as a discipline is involved in a process of reconstruction. At the moment theology mostly is a network of interrelated disciplines: systematic, literary, historical, practical and empirical disciplines and religious studies. In this interdisciplinary network - with shifting points of gravitation: from systematic theology to (inter)religious studies - the discipline spirituality has to find its place.

Notwithstanding the problematic relation with the whole of theology, the last century spiritual theology started to develop a profile as an academic discipline.

Firstly, in line with a tradition of treatises, there is a stream of handbooks, reflecting in a systematic way (broadly documented, articulated in an orderly sequence, thoroughly thought through) on the phenomenon of spirituality.

Secondly, the last decades scientific tools are developed: the proliferation of academic study programs, the establishing of scholarly institutes, and the production of reference works, to mention only the Dictionnaire de Spiritualité and World Spirituality.

Thirdly, the study of spirituality started to become interdisciplinary, within the network of theological disciplines and other disciplines in the academy. ${ }^{8}$

Fourthly, fundamental spirituality is growing, inspired by thinkers as Rahner, Lonergan, Levinas and others, reflecting on the 'paradigms' of the last decades (experiential, liberation, feminist, interreligious and other spiritual designs).

Finally, within the multiplicity of paradigms and designs the concentration on the experiential and processual character of divine-human transformation is growing.

\footnotetext{
See Waaijman, Spirituality, 392-397.

8 See S. Schneiders, 'The study of Christian spirituality: Contours and dynamics of a discipline', in: Studies in Spirituality 8 (1998), 38-57. For a loyal and critical reflection see the fundamental contribution of J. Berling, 'Christian spirituality: Intrinsically interdisciplinary', in: Exploring Christian spirituality: Essays in honour of Sandra M. Schneiders (Ed. B. Lescher \& E. Liebert), New York-Mahwah (NJ) 2006, 35-52. For an insight in this starting process from the viewpoint of mysticism see J. Baers, 'Evoluerend Westers denken over mystiek in de twintigste eeuw', in: Encyclopedie van de mystiek: Fundamenten, tradities en perspectieven (Ed. J. Baers et al.), Kampen-Tielt 2003, 137-238.
} 
All these developments have resulted in the fact, that in several faculties of theology, spirituality has been accepted in the academy. ${ }^{9}$

Theories. Success creates sometimes its own problems. Toward the end of the $19^{\text {th }}$ century systematic theology liberated spirituality from its arbitrary ascetic organisation. It provided theological principles for a restructuring of the discipline of spirituality, named theologia spiritualis ${ }^{10}$. The dogmatic-moral dominance was broken by a new perspective: experience, both psycho-existential and socio-cultural. ${ }^{11}$ After 50 years of 'emancipation' however, it seems wise to rethink the theoretical implications of this choice.

Firstly, the last decades' different designs, all constructed on experience as basic category are developed: liberation spirituality and feminist spirituality, contextual spirituality and inculteration spirituality, ecological and peace spirituality and so forth. Presented as 'paradigm shifts', they need a fundamental reflection. This we can name: fundamental spirituality. ${ }^{12}$

Secondly, spirituality as experience is blind. Experience needs a critical feedback from an ethical perspective. All spiritualities have their specific configuration of virtues (justice, mercy and love, reverence, and so forth). Virtues are the essential formative power, ${ }^{13}$ asking for the virtue of prudence (diakrisis, discretion) to focus on the end goal and to preserve the balance between aim and means.

Thirdly, it is impossible to understand spiritual texts without knowledge of the symbol system, at the background of which spiritual processes are lived through. Therefore The Blackwell Companion to Christian Spirituality rightly provides a specific part on theology and Christian spirituality encompassing essential elements of the symbol system: Trinity, Christology, the Holy Spirit, the human person, the Church, the sacraments, and ethics. ${ }^{14}$

Professions. Spirituality is intrinsically connected with practices and professions. One may even say, that a practice 'is not merely something useful, but is a constitutive dimension of the discipline'. ${ }^{15}$ Spiritual practices are multilayered phenomena.

9 To mention only two documents: Theologia spirituale: Temi e problemi (Ed. M. Gioia), Rome 1991; Exploring Christian spirituality (Ed. B. Lescher \& E. Liebert).

10 For a short description of this approach see Waaijman, Spirituality, 381-385.

11 Ibid., 385-391.

12 Seminar Spiritualität (Ed. A. Rotzetter), Zürich etc. 1979-1982, vol.1, 9.

13 E. Wyschogrod, Saints and postmodernism: Revisioning moral philosophy, Chicago 1990.

14 The Blackwell companion to Christian spirituality (Ed. A. Holder), Malden (MA) 2005, Part IV, 175-286.

15 E. Liebert, 'Practice', in: The Blackwell companion to Christian spirituality, 496. 
Firstly, there is the area of exercises: processes of appropriation, innerly oriented on 'purity of heart', the practical objective (skopos) of spiritual exercises, looking for the receiving of contemplation (telos); the practice of virtues, both precondition and essence of spiritual practices; meditation and prayer; mystical transformation. ${ }^{16}$ This inner horizon of the enormously rich variety of exercises is looking for careful description and interpretation.

Secondly, exercises are impossible without forms of facilitation, such as ministry in faith communities, formation in religious life, retreats, lectio divina, psalm reading, and so forth. It needs a careful phenomenological description and interpretation of these varieties of facilitating.

Thirdly, spiritual accompaniment deserves special attention as a paradigmatic form and place of facilitating spiritual growth. ${ }^{17}$

Fourthly, all practices and facilitating interventions are directed toward mystagogy as their centre, where human experience 'is made transparent down to the experience of mystery, the mystery that is God'. ${ }^{18}$

There is a huge amount of studies on practical spirituality. Mostly these practices are isolated from one another and from its mystagogical dimension. But what is more important is that they are isolated from the discipline spiritual theology and its theoretical background. Precisely on this point the contribution 'Practice' of Elizabeth Liebert is ground breaking. ${ }^{19}$ Comparing spirituality and practical theology she points at the commitment shared by both disciplines: experience. Starting from this essential point she proposes a constructive suggestion for the academic study of spirituality concerning 'practice'.

Words. Within the framework of Christian theology at least two areas seem to be constitutive, because they supply the positive data of Christian spirituality: scripture and history of Christianity. ${ }^{20}$ This is, mutatis mutandis, also true for Jewish, Islamic, Hinduistic, Buddhist and other world spiritualities. To understand these textual data, knowledge of vocabularies is basic. Within Christian traditions a wide range of dictionaries are available. For Old Testament 'words' two dictionaries are indispensable: Theologisches Handwörterbuch zum Alten Testament (1971-1976) and Theologisches Wörterbuch zum Alten Testament (1973-2000).

16 For an overview see Waaijman, Spirituality, 662-687.

17 For a structural analysis of this practice see Waaijman, Spirituality, 874-894. See also Sacred is the call: Formation and transformation in spiritual direction programs (Ed. S.M. Buckley), New York 2005.

18 M. Plattig, 'Mystik, mystisch - Ein Modewort oder die Charakterisierung des "Frommen von Morgen” (Karl Rahner)', in: Wissenschaft und Weisheit 60 (1997) no.1, 113-114.

19 Liebert, 'Practice', 496-514.

20 See Schneiders, 'The study of Christian spirituality', 43-44. 
These lexicons include the whole spiritual vocabulary of the Old Testament. For New Testament spirituality Theologisches Wörterbuch zum Neuen Testament and Exegetisches Wörterbuch zum Neuen Testament (1978-1983) have the same function.

Regarding spirituality in Church's history, the Dictionnaire de Spiritualité (1932-1995) is still a fundamental source of information. All 'doctrinal' entries follow the same format: bible (Old and New Testament) and history (patristics, middle ages, and modern periods). An important theological updating is the Nuevo Dizionario di Spiritualità (1979). New 'vocabularies', both in lived and studied spirituality, are The New Dictionary of Catholic Spirituality (1993) and The New SCM Dictionary of Christian Spirituality (2005).

To have a closer look into the place of spirituality within the whole of theology, the Lexicon für Theologie und Kirche gives us a good insight. In the Regis$t_{e}{ }^{21}$ we see how mysticism and religious life have their place, ${ }^{22}$ moreover where spirituality has its place within the systematic of theology. ${ }^{23}$

Things. Every spirituality is deeply interwoven with a 'world' in the phenomenological sense of the word: body, clothes, food, house, work, property, place, economy, environment, and nature. In journals (for spirituality), the last decades this dimension became increasingly important. To mention only a few titles.

Embodiment (The Way 1995)

Inhabitable Places (La Vie Spirituelle 1980)

The Earth (La Vie Spirituelle 1994)

I have to Work - You Too? (Speling 1979)

The World of Work (La Vie Spirituelle 1998)

Assessing Property at its True Value (Speling 1987)

The Spirit of Money (Speling 1976)

These titles point at an interest in themes belonging to the material culture. The New Dictionary of Christian Spirituality arranged systematically entries for this area: body, food, clothes etc.

Meanwhile systematic research dealt with this dimension of the so called 'everyday spirituality' in different countries. ${ }^{24}$ Some of these studies articulate

21 Lexikon für Theologie und Kirche (Ed. J. Höfer \& K. Rahner), Freiburg 1967, Register.

22 Ibid., 440-441; 450-453; 472-478.

23 See ibid., 508.

24 In Italy: C. Burini, La spiritualità della vita quotidiana negli scritti dei Padri, Bologna 1988. In the Netherlands: M. de Haardt, 'Kom eet mijn brood...': Exemplarische verkenningen naar het goddelijke in het alledaagse, Nijmegen 1999. In the English speaking world: D. Bergamt, The world is a prayerful place: Spirituality and life, Wilmington 1987; A. Ciorra, Everyday mysticism, 
a theoretical framework, to understand this shift in perspective: after centuries of negative attitudes toward the 'world', now a clearly positive relation is developed ${ }^{25}$. For this fundamental framework, the spiritual theology of Karl Rahner is very influential ${ }^{26}$. Also the writings of Michel de Certeau have contributed to such a fundamental reflection. ${ }^{27}$ An interesting contribution from a Jewish perspective could be Totality and Infinity of Emmanuel Levinas. In the second part of his main work, entitled Interiority and Economy, he describes the material culture as interiority: the dwelling, which is the embodiment of being at home with oneself in enjoyment, constitutes the centre from the perspective of which labour, possession, intimacy, hospitality and contemplation are unfolded. ${ }^{28}$

Images. Beauty and art had their place in spiritual theology from Clement of Alexandria and Augustine to Hans Urs von Balthasar and Paul Evdokimov. All created beauty reflects and participates in the Divine, the beauty itself and the source of all beauty. ${ }^{29}$

But these magnificent reflections of spiritual theology, by and large more focussed on beauty as transcendentale, ${ }^{30}$ has often lagged the practice of spiritual people in their devotions and exercises, a practice with many accents. Some traditions favoured a style of austere beauty and formal simplicity, such as Cistercian architecture. Others preferred a wealthy of expressions, such as the Baroque art and the oratories of Händel. In practice, spiritual people make abundant use of various arts (music, architecture, sculpture, icons, dance, drama)

New York 1995. In Germany: Weltfrömmigkeit: Grundlagen, Traditionen, Zeugnisse (Ed. A. Zottl), Eichstadt-Wien 1985; O. Betz, Das Unscheinbare is das Wunderbare: Spiritualität im Alltag, Eschbach 1994; Gott finden: Auf dem Weg zu einer Spiritualität des Alltags (Ed. W. Rück), Würzburg 1994.

25 A. Bettinger, Leben im Alltag der Gegenwart: Herausforderung an die christliche Spiritualität: Grundlegung und Kriterien gegenwartsbezogener Alltags-Spiritualität, Würzburg 1995.

26 E. Klinger, Das absolute Geheimnis im Alltag entdecken: Zur spirituellen Theologie Karl Rahners, Würzburg 1994; D. Marmion, A spirituality of everyday faith, Louvain 1998.

27 Particularly M. de Certeau, Linvention du quotidien. Part 1: Arts de faire. Part 2: Habiter, cuisinier (with L. Giard \& P. Mayol), Paris 1990-1994 (new edition).

28 For a short description of this spiritual framework see Waaijman, Spirituality, 68-71.

29 For a short overview of spiritual theology and aesthetics see A. García-Rivera, 'Aesthetics', in: The Blackwell companion to Christian spirituality, 345-362. See also: R. Lovelace, Christian art, London 2007.

30 See H. Urs von Balthasar, The glory of the Lord: A theological aesthetics, San Francisco 19821989. See also S. van Erp, The art of theology: Hans Urs von Balthasar's theological aesthetics and the foundations of faith, Leuven 2004; A. Nichols, Redeeming beauty: Soundings in sacral aesthetics, Abington 2007; Fruitful performances: Enacting Christian tradition (Ed. T. Hart \& S. Guthrie), Abington 2007. 
whereas spiritual theologians have focussed more on intellectual and 'spiritual' beauty, art having a lower place on the ladder of ascent. Moreover, these reflections paid relatively little space to real art and artistry. This inadequacy is understandable from a rather platonic approach: art may be seductive in its 'sensual' appeal. It is not 'true' in its representation, it over-indulges the 'emotions', and it is often 'entertainment'.

Nevertheless, beauty, art, and imaginative expressions still play an enormous role in religious experience and spiritual practice. It needs a spiritual hermeneutic for art, more positive toward body and senses, and open for the breadth of art. This hermeneutic helps us to understand how aesthetic expressions, such as music, movement, colour, light and design may convey a sense of the divine reality and how art can be a mediation in the divine-human transformation. ${ }^{31}$

Texts. Spiritualities preserve a variety of texts (sacred texts, mystical texts, ritual texts, rules etc.), as road and guidance for the spiritual journey. Amongst these texts sacred texts are fundamental. ${ }^{32}$ Spiritualities surround them with special care and respect. ${ }^{33}$ Within the whole of theology exegesis of sacred texts is a central task. One of the important developments within exegesis is the emergence of biblical spirituality. ${ }^{34}$ Three levels can be distinguished. ${ }^{35}$

Firstly, in biblical texts spiritualities are expressed. In this sense, we speak for example about the spirituality of the Psalms. ${ }^{36}$ Spiritual experiences, expressed in biblical narratives (Moses on Mount Sinai, Elijah on Mount Horeb; the Damascus experience of Paul, and so forth), are extensively studied. ${ }^{37}$

31 See for these challenges D. Freedberg, The power of images, Chicago-London 1989; J. Gruchy, Christianity, art, and transformation, Cambridge 2001; R. Viladesav, Theological aesthetics: God in imagination, beauty and art, New York 1999; F. Maas, Schoonheid vraagt om goed gezelschap, Vught 1997; K. Waaijman, 'Mystiek in de beeldende kunst', in: Encyclopedie van de mystiek, 108-121; J. Marion, 'Das Prototyp des Bildes', in: Wozu Bilder im Christentum? Beiträge zur theologischen Kunsttheorie (Ed. A. Stock), St. Otttilien 1990, 117-135; G. Koch, Spiritualität in Bewegung: Tanz als Gestalt religiösen Lebens, Mainz 2002.

32 S. Schneiders, 'Foundations of spirituality', in: Scripture as the soul of spirituality (Ed. E. Malony), Collegeville (MN) 2005, 1-22; B. Bowe, Biblical foundations of spirituality, Lanham (MD) 2003.

33 A. Grafton \& M. Williams, Christianity and the transformation of the book, London 2006.

34 See the foundational studies of S. Schneiders, 'Biblical spirituality: Life, literature, and learning', in: Doors of understanding: Conversations in global spirituality in honor of Ewert Cousins (Ed. S. Chase), Quincy (IL) 1997, 51-76; Id., 'Biblical spirituality', in: Interpretation 56 (2002), 133-144; J. Donahue, 'The quest for biblical spirituality', in: Exploring Christian spirituality, 73-97; K. Berger, Was ist biblische Spiritualität? Gütersloh 2003.

35 See Schneiders, 'Biblical spirituality', 135-136.

36 W. Brueggemann, Spirituality of the psalms, Minneapolis 2002; C. Stuhlmueller, The spirituality of the psalms, Collegeville (MN) 2002.

37 See for example H. Welzen, 'De mystiek van het Nieuwe Testament', in: Encyclopedie van de mystiek, 521-538. 
Secondly, forms of life, deeply patterned by biblical motives. In this sense, the great monastic rules are steeped in biblical spirituality. ${ }^{38}$

Thirdly, processes of Bible reading are studied: processes of appropriation, leading to transformation. The praxis of spiritual reading (lectio divina, pardes, and so forth), structurally examined, may constitute the blueprint for a spiritual hermeneutic. ${ }^{39}$ Texts can become an initiation into mysticism. ${ }^{40}$ In this respect some texts are favourite literature: the Psalms, the Song of Songs, the Our Father, the Gospel of John, and so on. They are a source and guidance on the spiritual journey. ${ }^{41}$

Seen from a methodological perspective some exegetical approaches are more promising for a fruitful intradisciplinary cooperation than others. 'Approaches that respect the final form of texts, such as narrative criticism, canonical criticism, and intertextual readings, as well as those that access the effect of a text on readers, such as reader response criticism, are most helpful. When joined to critical readings of those texts that have been oppressive throughout history, those methods become a vital part of spirituality. ${ }^{42}$ These approaches facilitate and improve the growing cooperation between spirituality and exegesis in theology.

Histories. According to Sandra Schneiders the history of 'Christian Faith' supplies together with biblical traditions 'the positive data of Christian religious experience as well as its norm and hermeneutical context'. ${ }^{43}$ This broadly accepted triad, articulating the 'constitutive' role of history in the discipline of spirituality, can probably function as an agenda, provoking important questions.

Regarding history as a container of positive data, it cannot be denied that the last two centuries a huge amount of historical material has been presented mostly of high quality, to mention only Pourrat, Bouyer, Flors, McGinn, Ruh, Dinzelbacher and Jewish scholars as Scholem, Dan, Idel, and so forth. There are numerous surveys and details studies. What is surprising here is that there seems no 'dominance' to be felt as is the case of systematic theology. The questions remain whether the historical reconstructions are representive? ${ }^{44}$ Is lay

38 The Imitation of Christ of Thomas a Kempis is deeply modelled according the gospel of John. See K. Waaijman and others, Nuchtere mystiek: Navolging van Christus, Kampen 2006.

39 Waaijman, Spirituality, 690-773.

$40 \mathrm{H}$. Welzen, 'An initiation into mystical life: The Gospel according to Mark', in: Studies in Spirituality 5 (1995), 86-103.

41 For an overview of the appropriation of the Bible in Christian spirituality see B. Green, 'The Old Testament in Christian spirituality', in: The Blackwell companion to Christian spirituality, 37-54; B. Thurston, 'The New Testament in Christian spirituality', in: Ibid., 55-70.

42 Donahue, 'The quest for Biblical spirituality', 87.

43 S. Schneiders, 'The study of Christian spirituality: Contours and dynamics of a discipline', in: Christian Spirituality Bulletin 6 (1998) no.1, 3.

44 P. Sheldrake, Spirituality and history: Questions of interpretation and method, London 1991. 
spirituality 'consistently overlooked and unappreciated'?45 Are counter voices and esoteric spiritualities objectively presented? How to develop a global perspective? ${ }^{46}$

Regarding history as a norm, many questions arise. The most important is: whose history? How do we know the 'whole' of Christian tradition, if the most of Christian experience is hidden in the future? Which historical perspectives provide a norm? What is exactly a 'norm'?

Regarding the hermeneutical framework, this role of history is self-evident, as far as history is the socio-cultural context of spirituality, firstly conceptualized by Michel de Certeau in his ground breaking article Culture and Spiritual Experience (1966), widely accepted as hermeneutical framework..$^{47}$

Processes. Taking as a point of departure the thesis, that spirituality is about experience, ${ }^{48}$ we may sharpen this rather broad orientation to a more precise focus: spiritual experience as a way, ${ }^{49}$ a multilayered process of divine-human transformation. ${ }^{50}$

Groundbreaking for this processual focus is the article of Hein Blommestijn 'Progrès-progressants', ${ }^{51}$ which he exemplified in many articles, published in the journal Speling. This perspective can also be observed in monographies on John of the Cross, Beatrice of Nazareth and Ruusbroec. ${ }^{52}$

45 E. Sellner, 'Lay spirituality', in: The new SCM dictionary of Christian spirituality (Ed. P. Sheldrake), London 2005, 589.

46 The Blackwell companion to Christian spirituality concludes Part III on 'Christian spirituality in history' rightly with an article from a global perspective: R. Fox Young, 'Christian spirituality in Africa, Asia, Latin America, and Oceania', in: The Blackwell companion to Christian spirituality, 156-174 (after an article on Europe and North America!). See also the literature of liberation spirituality: H. Brandt, Spiritualität und Protest: Religion und Theologie in Lateinamerika, Neuendettelsau 2005.

47 M. de Certeau, 'Cultural and spiritual experience', in: Spirituality in the secular city, New York 1966, 3-31 (Concilium, vol. 19).

48 C. Truhlar, Concetti fondamentali della teologia spirituale, Brescia 1971; K. Rahner, Theological investigations. Vol. III, Baltimore-London 1967; Schneiders, 'The study of Christian spirituality', in: Studies in Spirituality 8 (1998); Idem., 'The discipline of Christian spirituality and Catholic theology', in: Exploring Christian spirituality, 196-212.

49 See K. Waaijman, 'Mystieke ervaring en mystieke weg', in: Encyclopedie van de mystiek, 57-59.

50 For this multilayered core concept see Waaijman, Spirituality, 455-481.

51 H. Blommestijn, 'Progrès-progressants', in: Dictionnaire de spiritualité ascétique et mystique (Ed. M. Viller, F. Cavallera \& J. de Guibert), Paris 1986, vol. 12 (part 2), 2383-2405.

52 R. Luévano, Endless transforming love: An interpretation of the mystical doctrine of Saint John of the Cross according to the soul's affective relation and dynamic structures, Roma 1990; J. Huls, 'Seuen maniren van minnen' van Beatrijs van Nazareth: Het mystieke proces en mystagogische implicaties, Leuven 2002; L. Swart, De articulatie van de mystieke omvorming in 'Die geestelike Brulocht' van Jan van Ruusbroec, Nijmegen 2006. 
It needs a fundamental study of the multilayered process of divine-human transformation, including the essential guidance of the virtue of all virtues: the discernment (fronèsis, diakrisis, discretio, prudentia), being the lumen intellectualis which is the formal object of spiritual theology, providing both the orientation for the interpretation of images, texts and histories ánd the inner light of spiritual practices and accompaniment. ${ }^{53}$

Relationships. 'In the Judeo-Christian tradition spirituality is conceived of as an expression of a relationship with God, neighbour and self' ${ }^{54}$ In Jewish spirituality this insight was not dominated by individualism as in Christian spirituality. Hassidic spirituality was characterized by community, grounded in the divine reality of the ten Sefiroth. ${ }^{55}$ In Christian spirituality, the Second Vatican Council was a breakthrough. Particularly, the theology of the Trinity opened new perspectives on the spirituality of community. 56

Trinity means, first of all, that the divine reality itself is a communion: 'The mystery of God is profoundly relational, and this relational mystery is expressed in the language of Father, Son, Spirit. ${ }^{57}$

In this divine community the human community is grounded: 'Human relationships in all spheres of life are to be brought into conformity with the equality, mutuality and interdependence that characterize the divine life' ${ }^{58}$ The trinitarian spirituality has deeply influenced the renewal of community spirituality. In this sense one may say: 'The doctrine of the Trinity is an eminent practical teaching, expressing not only who and how we understand God to be, but what we think human persons are called to be and become: created to glorify God by living in communion with God and one another through Christ in the Spirit'. ${ }^{59}$

Not only the human community, but also the community of all creatures is grounded in the Mystery of the Trinity: 'Just as the divine life of the Trinity shares a dynamic spiritual economy of love, so creation is formed as an ecology, an ordered and relational network of material interdependence and connectivity. ${ }^{60}$

53 For an exploration of this option see Waaijman, Spirituality, 482-591.

54 M. Pryce, 'Relationships', in: The new SCM dictionary of Christian spirituality, 536.

55 M. Buber, Schriften zum Chassidismus, München-Heidelberg 1963.

56 M. Downey, Altogether gift: A Trinitarian spirituality, Maryknoll (NY) 2000; see also O. Steggink, 'Ontmoeting en spiritualiteit', in: D. Hutsebaut et al., Is er meer tussen ons? Over relaties en hun religieuze betekenis, Baarn 1980, 34-44.

57 M. Downey, 'Trinity and spirituality', in: The new SCM dictionary of Christian spirituality, 624.

58 Ibid., 625.

59 Ibid., 624. See B. Lee, The Catholic experience of small Christian communities, New York 2000.

60 Pryce, 'Relationships', 536. 


\section{Spirituality AND Religious STUdies}

The study of religion has significantly contributed to helping spirituality and mysticism move away from the atmosphere of prejudice which shaped the climate of the late $19^{\text {th }}$ century. The descriptive and comparative mentality which marks this discipline showed that spirituality and mysticism are a constant element in religion.

The study of religion is performed by a wide range of disciplines. The same multidisciplinarity is reflected in the study of spirituality. For both religion ánd spirituality is true: 'Progress in academic studies depends deeply on methodological exchange with other disciplines' ${ }^{61}$

Disciplines. At the end of the nineteenth century, William Inge, looking at it from a science-of-religion perspective, showed that mysticism is present in all religions as a specific element, focussing the mind on supra-rational reality. ${ }^{62} \mathrm{~A}$ decade later, Friedrich von Hügel demonstrated phenomenologically that religion is a complex containing three elements: mysticism, dogma and institution. There always exists a threat that one of these elements will dominate and absorb the other two. The specific nature of mysticism is that the Infinite Spirit permeates the finite mind, a phenomenon initially revealing itself in experiences of contingency and transitoriness, but finally leading to the mystical union. ${ }^{63}$ From now on spirituality belongs explicitly to the material object of religious studies: spirituality (the lived relationship between God and man), along with the doctrinal element (the consistent formulation of the God-man relationship), the ethical element (the God-man relationship expressed in practice) and the ritual element (the performance of the God-man relationship within community), constitutes the whole of religion. ${ }^{64}$

Regarding the formal object: the study of religion itself - as the study of spirituality does - goes into the direction of an encyclopedic matrix of disciplines. The two volume publication New Approaches of the Study of Religion, reflecting on 'what has transpired in academic approaches to the study of religion over the last two decades of the twentieth century', ${ }^{65}$ mentions textual, historical, philosophical, sociological, psychological and cross-cultural approaches (to mention

61 P. Antes, A. Geertz \& R. Warne, 'Introduction', in: New approaches to the study of religion (Ed. P. Antes, A. Geertz \& R. Warne), Berlin-New York 2004, vol. 1, 8.

62 W. Inge, Christian mysticism, London 1899.

63 F. von Hügel, The mystical element of religion as studied in Saint Catharine of Genoa and her friends, London 1908.

64 J. Walgrave, Op de grondslag van het Woord, The Hague 1965, 121-126.

65 Antes, Geertz, \& Warne, 'Introduction', in: New approaches to the study of religion, vol. 1, 7. 
only the most important ones and not included the older and still existing approaches). ${ }^{66}$ The study of spirituality reflects this interdisciplinarity of religious studies. ${ }^{67}$

The interplay between religious studies and the study of spirituality highlights two moments: forms of spirituality, their structure and function within a given religion, come sharply to the fore; the multiplicity of comparable forms gives rise to the question concerning resemblances and differences. It needs a fundamental framework for more systematic reflection on interdisciplinarity and comparativety. ${ }^{68}$

Theories. The study of religion is not only interdisciplinary constructed, but this interdisciplinarity itself is interwoven by a multiplicity of methodologies and approaches. From its origin as an academic discipline in the nineteenth century up until the end of World War II the study of religion was marked by a phenomenological and textual approach. ${ }^{69}$ In the post World War II period up until the eighties the humanities and the social sciences came in. ${ }^{70}$ In the last two decades studies are more context-related (linguistically, politically, religiously, culturally), more self-critical (the relationship between reality and the study of religion; the socio-psychological position of the researcher; history as construction), more hermeneutical (the problem of translation), more empirical (the upcoming of sociology of religion and cross-cultural research), and so on. ${ }^{71}$

Looking to fundamental questions in this field, one question plays permanently at the background: is mysticism a phenomenon that transcends all religious forms and schools, or is it essentially part of the religion it belongs to. Religious studies move between these extremes. ${ }^{72}$ Some scholars presuppose a

66 J. Waardenburg, Classical approaches to the study of religion, The Hague 1973; F. Wahling, Contemporary approaches to the study of religion. I. The Humanities: II. The social sciences, The Hague 1984-1985.

67 See for instance: J. Hollenback, Mysticism: A comparative historical study, Ann Arbor (MI) 1991; H. de Wit, Contemplatieve psychologie, Kampen 1987; G. Winter, Community and spiritual transformation: Religion and politics in a communal age, New York 1989; A parliament of souls: In search of a global spirituality. Interviews with 28 spiritual leaders from around the world (Ed. M. Tobias et al.), San Francisco 1995.

68 B. Chilton \& J. Neusen, Comparing spiritualities: Formative Christianity and Judaism on finding life and meeting death, Harrisburg 2000.

69 Waardenburg, Classical approaches to the study of religion.

70 Wahling, Contemporary approaches to the study of religion.

71 New approaches to the study of religion.

72 For an overview see P. Widmer, 'Die angelsächsische Mystikdebatte', in: Handbuch Spiritualität: Zugänge, Traditionen, interreligiöse Prozesse (Hrsg. K. Baier), Darmstadt 2006, 61-67; Id., Mystikforschung zwischen Materialismus und Metaphysik: Eine Einführung, Freiburg i.Br. 2004. 
kind of abstract mystical religion. Secondarily and under a kind of compulsion contents of faith (e.g. Trinity in Christian mysticism) were added to the so called pure mystical experience, ${ }^{73}$ being a kind of 'spiritual foundation of all religions'. Other scholars argue that mysticism detached from its religious setting is nonexistent; there is no mysticism as such, there is only the mysticism of a particular spiritual tradition (Jewish, Christian, Islamic, and so on). ${ }^{74}$ In the dialectic tension of these extremes, scholars are analysing particular mystical phenomena and comparing them, in search for similarities and differences, without ipso facto adhering to the presupposition of an abstract mystical religion. ${ }^{75}$ Probably a dou-

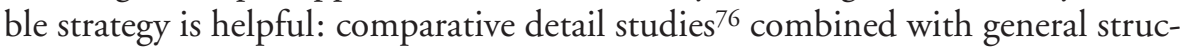
ture analysis. ${ }^{77}$

Professions. Up until the end of World War II the study of religion was 'marked by a phenomenological and textual emphasis' ${ }^{78}$ It was not directly related to a practice in church or society, except perhaps in the original stage of the discipline. Whatever may be the reason, no broad scholarly attention has been paid for spiritual professions and practices. Nevertheless, the last decade the urgency of practioners in this field has become evident. Within processes of globalisation and migration intercultural and interreligious interactions are of a growing importance, on all levels of society. From a viewpoint of spirituality an intercultural and interreligious approach of professions in health care, education, business, mass media, and so on is needed.

73 J. Baruzi, S. Jean de la Croix et le problème de l'expérience mystique, Paris 1931 (orig. ed. 1924); P. Almond, Mystical experience and religious doctrine: An investigation of the study of mysticism in world religions, Berlin etc. 1982; The problem of pure consciousness: Mysticism and philosophy (Ed. R. Forman), Oxford 1990; The innate capacity: Mysticism, psychology, and philosophy (Ed. R. Forman), Oxford 1998; M. Müller, Einleitung in die vergleichende Religionswissenschaft, Strassburg 1874, 15-16.

74 G. Scholem, Major trends in Jewish mysticism, London 1955, 1-39; J. Dan, 'In quest of a historical definition of mysticism', in: Studies in Spirituality 3 (1993), 58-90; Mysticism and philosophical analysis (Ed. S. Katz), London 1978, Mysticism and religious traditions (Ed. S. Katz), New York 1983; Mysticism and language (Ed. S. Katz), New York etc. 1992.

75 W. Johnston, The inner eye of love: Mysticism and religion, London 1978; B. Butler \& T. Butler, Just spirituality in a world of faiths, London 1996; M. Jaoudi, Christian and Islamic spirituality: Sharing a journey, Mahwah (NJ), 1993; L. Sita, Worlds of belief: Religion and spirituality, Woodbridge (CT) 1996; M. Piantelli, La spiritualità delle grandi religioni, Palermo 1989.

76 F. Clooney, 'Comparative theology: A review of recent books (1989-1995)', in: Theological Studies 56 (1995), 521-550; Id., 'The mystic heart: Discovering a universal spirituality in the world's religions', in: Spiritus 1 (2001) no.1, 121-123.

77 See for instance W. Teasdale, The mystic heart: Discovering a universal spirituality in the world's religions, Novato 1999.

78 Antes, Geertz, \& Warne, 'Introduction', in: New approaches to the study of religion, vol. 1, 1. 
Words. Within the study of religion, classically oriented on the interpretation of texts, some awareness of theoretical problems with translation has come up. 'A good example of the problem is the German tradition of using the German mystical vocabulary of the late Middle Ages to translate the key terms of Islamic mysticism, a practice that leaves the reader with the impression that religious experience in Islamic mysticism has striking parallels with that of German Christian mystics ${ }^{79}$ Here a very important problem on the level of 'words' has been signalized. Parallel words, chosen by the translators, are not necessarily justified parallels.

Although there is a rich tradition of language dictionaries in the field of religious studies, including the spiritual vocabularies, and also encyclopedias, including spiritual terminologies ${ }^{80}$ this new problematic of translation and comparison is a challenge for the study of spirituality within religious studies.

Things. Being mainly oriented on texts, histories, and the comparison of mystical processes, the study of spirituality in the field of religions was not interested in the material culture of spirituality. Meanwhile the world has been changed by processes of globalisation and migration, deeply influenced by economic interests. Religions are involved in political tensions and sometimes ideologically present in some military conflicts. It is impossible to neglect the material infrastructure of spirituality in the context of world's religions.

Images. In most of the religions, culture, art and spirituality are not separate fields of experience. In this sense, religions always use some art: 'If a religion forbids the making of images, recourse will be had to music, arabesques, dance; if it forbids the use of song, men will cultivate the graces of speech; if it frowns on the theatre or the use of musical instruments, it will allow room for architecture or poetry' ${ }^{81}$

Some research on art and spirituality in different religions and worldviews has been done. ${ }^{82}$ Cross-cultural and comparative studies are made, looking for similarities, and differences. ${ }^{83}$ Art seems to function as a vehicle by which human

79 Ibid., 6-7.

80 See the monumental The encyclopedia of religion (Ed. M. Eliade), New York etc. 1987 (16 vols.).

81 P. Weiss, Religion and art, Milwaukee 1963, 15.

82 Ch. Chang, Creativity and Taoism, New York 1963; E. Coleman, Philosophy of painting by Shih Táo, The Hague 1978; A. Coomaraswamy, Christian and Oriental philosophy of art, New York 1956; R. Jhanji, The sensuous in art: Reflections on Indian aesthetics, Shimla 1993; S. Nasr, Islamic art and spirituality, New York 1987; J. Drury, Painting the Word: Christian pictures and their meanings, New Haven-London 1999.

83 A. Greeley, Religion as poetry, New Brunswick-London 1995; J. Martin, Beauty and holiness: The dialogue between aesthetics and religion, Princeton 1990; Th. Martland, Religion as art, Albany 1981; Weiss, Religion and art; E. Coleman, Creativity and spirituality: Bonds between art and religion, Albany (NY) 1998. 
beings reach for the divine and receive it. It fosters the feelings of unity. The particular and the universe, space and time, receptivity and omnipresence, the human and the divine are experienced as one.

The very source of these feelings of unity are probably the spiritual processes from which they come, essentially characterized by senso-motorical transformation. As Evelyn Underhill states:

The painter really sees his unpainted picture, the novelist hears the conversation of his characters, the poet receives his cadences ready-made. (...) In the mystic the same type of activity constantly appears. Profound meditation takes a pictorial or dramatic form (...) 'interior voices' and 'imaginary visions' which are sometimes (...) indistinguishable from the ordinary accompaniments of intense artistic activity. ${ }^{84}$

Texts. For decades the classical approach in the field of spirituality and religious studies was textual analysis and translation, for which philological methods were used. ${ }^{85} \mathrm{~A}$ rich harvest of editions and translations was the result. One of the most important contributions has been the stream of studies on texts of the Asian spiritualities, particularly from the Hinduistic and Buddhist traditions. To give only one example, Max Müller, translator of the Rigveda and founder of the study of religion, translated from 1875 till 1900 his Sacred Books of the East, encompassing spiritual texts from different traditions: Hinduism, Buddhism, Zoroastrism, Islam, Daoism, and Confucianism. This was only the beginning of a stream of text editions and translations.

Groundbreaking for a further development of the interreligious interaction, present in the very texture of texts, is the intertextual approach: spiritual texts are not only intertextually related with texts of their own tradition, but also linked with texts from other traditions as Elisabeth Hense has shown in Zwischen Spiritualitäten. ${ }^{86}$ Concrete textual paradigms show an intense exchange of experiences and insights between major spiritual traditions. Analysing these (inter)texts, divergent or convergent horizons are unfolded, asking for further interpretation.

Histories. From the beginning of the twentieth century a stream of publications was set in motion in which spiritual themes and traditions are described and compared. As a starting point Heiler's Das Gebet (1918) and Die Bedeutung der Mystik für die Weltreligionen (1919) can be mentioned. These monumental works

84 E. Underhill, Mysticism: A study in the nature and development of man's spiritual consciousness, New York 1961, 272.

85 New approaches to the study of religion, vol. 2, section 1.

86 E. Hense, Zwischen Spiritualitäten: Intertextuelle Berührungen, Münster 2005. 
of religious studies opening up the area of the history of spirituality, countless editions, interpretations and cross-cultural studies, from a science-of-religion perspective are made. Names like Merton, Panikkar, Enomiya-Lasalle, Durkheim, Griffith and numerous others mark this path of comparative and cross-cultural research, ${ }^{87}$ sometimes organized around themes. ${ }^{88}$

A very important event in the field of spirituality and religious studies is the appearance of World Spirituality. An Encyclopedic History of the Religious Quest. ${ }^{89}$ In this encyclopedia the study of spirituality has an eminent new tool for research. Spirituality is conceived within the perspective of the global context. Considerable space is assigned to indigenous spiritualities ( 5 volumes). The field of larger spiritual traditions is competently and representatively mapped out by a staff of approximately 500 scholars who know these traditions from inside. This encyclopedia can be a step towards 'a new discipline in the field of religion, the discipline of spirituality' 90 and provides a basis for new forms of interdisciplinarity and interreligious dialogue. Sandra Schneiders correctly notes that in particular spirituality seems to posses the potential for a fruitful interreligious dialogue and the parameters for comparative studies. ${ }^{91}$

Processes. Over against a content oriented approach, dominated by a dogmaticneothomistic theology, Evelyn Underhill offered a refreshing look on mysticism, one which was grounded in an unbiased description of texts from Christian as well as non-Christian traditions. ${ }^{92}$ Underhill not only broadened the scope, looking to different religions, she also opened the eyes for the processual aspects of mysticism, for the 'development of man's spiritual consciousness'. Probably three

87 R. Flasche, 'Religiosität und Frömmigkeit in der neueren Religionen-Wissenschaft', in: Frömmigkeit: Gelebte Religion als Forschungsaufgabe (Ed. B. Jaspert), Paderborn 1995, 11-19; E. Bock, Meine Augen haben Dich geschaut: Mystik in den Religionen der Welt, Zürich 1991;

E. Deutsch, Religion and spirituality, New York 1995; L. Gardet, L'expérience du soi: Étude de mystique comparée, Paris 1981; E. Lasalle, Zen und die christliche Mystik, Freiburg i.Br. 1986; G. Parrinder, Mysticism in the world's religions, London 1976; G. Schmid, Die Mystik der Weltreligionen: Eine Einführung, Stuttgart 1990.

88 See for instance R. Sharf, 'Buddhist modernism and the rhetoric of meditative experience', in: Numen 42 (1995), 228-283; E. De Michelis, A history of modern Yoga: Patañjali and Western esoterism, London-New York 2004; K. Baier, Yoga auf dem Weg nach Westen: Studien zur Receptionsgeschichte, Würzburg 1998.

89 World spirituality: An encyclopedic history of the religious quest (Ed. E. Cousins), New York, 1985-......

90 Ibid., xiii.

91 S. Schneiders, 'Spirituality in the academy', in: Modern Christian spirituality (Ed. B. Hanson), Atlanta (GA) 1990, 15-37.

92 Underhill, Mysticism; E. Cousins, 'Preface', in: Christian spirituality: Origins to the twelfth century (World spirituality 16), London 1989, xiii. 
incentives may be important for further reflections on spiritual processes in the area of religions and spirituality.

Firstly within the global process of a growing system of interrelated religions we may observe that 'something like a global consciousness of interconnected spirituality will be formed' ${ }^{93}$ An interreligious perspective can give a deeper understanding of one's own spiritual tradition: 'By drawing the material (documentations of spirituality in an interreligious context, k.w.) into the focus of world spirituality, it can provide a perspective for understanding one's place in the larger process..$^{94}$

Secondly, scholars in the field of religious studies are increasingly aware of the fact 'that the way we look at the world and the type of questions we ask in our work [research in the field of religion k.w.] are conditioned by socio-psychological factors to a great extent, i.e. that we [scholars k.w.] are all "located knowers" whose specificity of perspective is relevant to the kinds of studies we engage in and the conclusions we draw'. ${ }^{95}$

Lastly, the mystical 'nothingness' is 'the "place" where true dialogue and the meeting of diverse religious traditions in an atmosphere of "reciprocal transparency" can occur. Such a creative rapprochement will facilitate an open dialogue in which the different mystical traditions can acknowledge their complementarity. ${ }^{96}$

Relationships. Within spirituality, a whole new genre of interspiritual literature has developed, reflecting on the plurality of spiritualities living together within a globalizing world. ${ }^{97}$ Relationships and interactions are documented on different levels: 'In recent years a typology has established itself: the dialogues of common life, common action, religious experience and theological exchange. ${ }^{98}$

Interspiritual relationships start with common life, 'by individuals and communities being prepared to enter sympathetically into the spiritual life of the

93 K. Baier, 'Spiritualitätsforschung heute', in: Handbuch Spiritualität, 13.

94 Cousins, 'Preface', in: Christian spirituality, xiv.

95 Antes, Geertz \& Warne, 'Introduction', in: New approaches to the study of religion, vol. 1, 5.

96 C. Kourie, Mysticism: A way of unknowing, Pretoria 2005, 8. See also K. Ceming, Einheit im Nichts: Die mystische Theologie des Christentums, des Hinduismus und Buddhismus im Vergleich, Augsburg 2004; K. Waaijman, 'Mystical perspectives in interreligious dialogue', in: Carmelus (forthcoming); The emptying God: A Bhuddist-Christian-Jewish conversation (Ed. B. Cobb Jr \& C. Ives), New York 1990.

97 M. Barnes, Religions in conversation, London 1989; Id., Theology and the dialogue of religions, Cambridge 2002; Religions in the modern world (Ed. L. Wood), London 2002.

98 M. Barnes, 'Spirituality and the dialogue of religions', in: The new SCM dictionary of Christian spirituality, 34 . 
other. (...) Dialogue begins when people, not systems, meet'. ${ }^{99}$ These meetings can happen on a local or international level, ${ }^{100}$ in informal or public form. ${ }^{101}$ 'Spirituality crosses cultural and religious boundaries because it focuses on practice, especially on the different forms of prayer which provide the inner energy or motivation for action. To that extent, a spirituality is almost by definition cross-cultural'. ${ }^{102}$

Interspiritual dialogue is embedded in common action. Basically this action is respect for the other: "What is "other" is to be welcomed as an invitation to a deeper faith rather than marginalized as a thread to be avoided'. ${ }^{103}$

Religious experience can be seen as the intensification of what has been perceived at the interpersonal level. For many people, spiritual dialogue has become essential for their spiritual journey. ${ }^{104}$ The question is: 'Does the experience of crossing the boundary, of entering into a relationship with what is other, have something to teach me about how I am to understand and live my own life of faith?'105

Theological reflection is needed to develop insight in the complex relationships between spiritualities and in the processual implications of entering the inbetween of the dialogue. 'The point is, that it is not similarity but the very "otherness" of these traditions, their refusal to sink differences, which opens up the space of dialogue. Each, in its own way, acknowledges the risk of reducing the Ultimate to some controllable form'. ${ }^{106}$

\section{Spirituality AND Philosophy}

Philosophy, in itself a network of disciplines (metaphysics, logic, epistemology, theory of knowledge, history of philosophy, ethics, practical philosophy, aesthetics,

99 M. Barnes, 'Theology of religions', in: The Blackwell companion to Christian spirituality, 407.

${ }^{100}$ See, for instance, the Monastic Inter-faith Dialogue.

${ }^{101}$ In 1986, Pope John Paul II met other faith leaders in Assisi.

102 Barnes, 'Theology of religions', 411. See also A. Race, Interfaith encounter, London 2001.

${ }^{103}$ Barnes, 'Spirituality and the dialogue of religions', 33. See also Thich Nhat Hanh \& Daniel Berrigan, The raft is not the shore: Conversations toward a Buddhist/Christian awareness, New York 2001.

104 See for this spiritual experience the section 'Spiritualität interkulturell, transreligiös', in: Handbuch Spiritualität, 247-344; see also R. Panikkar, The intrareligious dialogue, Mahwah (NY) 1978.

105 Barnes, 'Spirituality and the dialogue of religions', 34.

106 Ibid., 35. See F. Blee, 'Die Wüste der Alterität: Spirituelle Erfahrung im intermonastischen Dialog', in: Handbuch Spiritualität, 249-266; Id., Le désert de l'altérité: Une expérience spirituelle du dialogue interreligieux, Montréal 2004. 
cosmology, etc.), was intimately related with spirituality. ${ }^{107}$ In antiquity this relation was self-evident: philosophy wanted to be pious (sebas), was oriented on contemplation (theoria), prepared by the cultivation of virtue (askèsis). This relationship has been continued within the framework of Jewish, Christian and Islamic thinking. Also in modern times philosophy was rooted in the spiritual quest. ${ }^{108}$ In postmodern circles philosophy and spirituality come explicitly to one another. ${ }^{109}$

Disciplines. Philosophers are particularly interested in epistemological questions, such as the specific nature of mystical processes of knowing, ${ }^{110}$ the question of truth, ${ }^{111}$ and God. ${ }^{112}$ Is God really knowable? What is the cognitive faculty and what are the cognitive forms involved here? What happens with this knowing, when it approaches the unsayable truth? An increasing number of philosophers reflect on the basic structure of mysticism and the role of mystical experience in human consciousness. ${ }^{113}$

Not only the epistemological questions (knowledge, truth, and basic structures), but also the epistemological structure of the discipline of spirituality as

${ }^{107}$ For an overview see L. Dupré, 'Mystiek en filosofie', in: Encyclopedie van de mystiek (Ed. J. Baers et al.), Kampen-Tielt 2003, 238-256. See also Baier, 'Spiritualitätsforschung heute', 17-23; E. Wolz-Gottwald, 'Philosophie und Spiritualität', in: Handbuch Spiritualität, 186-198.

${ }^{108}$ K. Albert, Einfuihrung in die philosophische Mystik, Darmstadt 1996. See also S. Wendel, Affektiv und inkarniert: Ansätze deutscher Mystik als subjecttheoretische Herausforderung, Regensburg 2002; W. Göbel, Okzidentale Zeit: Die Subjektgeltung des Menschen im Praktischen nach der Entfaltungslogik unserer Geschichte, Freiburg 1996.

109 D. Griffin, Parapsychology, philosophy and spirituality: A postmodern exploration, Albany (NY) 1997.

110 Mysticism and philosophical analysis (Ed. S. Katz); K. Albert, Mystik und Philosophie, St. Augustin 1986; S. Iida, Reason and emptiness: A study in logic and mysticism, Tokyo 1980; The innate capacity (Ed. R. Forman); H. Myranek, Mystik und Vernunft: Zwei Pole einer Wirklichkeit, Olten-Freiburg i.Br. 1991; S. Paniker, Filosofia mistica: Una lectura de los griegos, Barcelona 1992.

111 J. Carloye, 'The truth of mysticism', in: The Monist 59 (1976) no.4, 551-562; J. Price, 'The objectivity of mystical truth claims', in: The Thomist 49 (1985), 81-98; The problem of pure consciousness (Ed. R. Forman); J. Sherrill, The metaphysics of higher spiritual consciousness, New York 1992.

112 W. Weischedel, Der Gott der Philosophen, Darmstadt 1972; Argumente für Gott: Gott-Denker von der Antike bis zur Gegenwart (Hrsg. K. Weger \& K. Bossong), Freiburg i.Br. et al. 1987; D. Loose \& A. de Wit, De God van de filosofen: Een omkeer van de fenomenologie, Budel 2005.

${ }^{113}$ For an overview see J. Baers, 'Evoluerend Westers denken over mystiek in de twintigste eeuw', in: Encyclopedie van de mystiek, 136-237. See also R. Margreiter, Erfahrung und Mystik, Berlin 1997; P. Widmer, Mystikforschung zwischen Materialismus und Metaphysik, Freiburg i.Br. 2004; S. Grätzel, Die Vollendung des Denkens: Vorlesungen zur Philosophie und Mystik, London 2005; G. Mondello, The metaphysics of mysticism: A commentary on the mystical philosophy of St. John of the Cross, Web-based book 2007, http://www.johnofthecross.com. 
such is asking for analysis. On a fundamental level, the discipline of spirituality itself should be analysed from the viewpoint of scientific systems, influencing the study of spirituality (idealism, positivism, pragmatism, phenomenology, ${ }^{114}$ empirism, existentialism, dialogical thinking, holism) and from the perspective of logic dealing with questions about category, definition, reasoning, consistency and so on. ${ }^{115}$

Theories. Philosophy is interested in fundamental questions concerning metaphysical and anthropological implications of spirituality, and in questions about the basics of rationality.

Philosophy forges basic concepts designed to help us understand and verbalize lived experience on its most fundamental level, or it reflects on basic concepts used in lived spirituality: tao, atman, self, ein-soph, unity, essence, presence, transcendence, ultimate reality, experience. ${ }^{116}$ Precisely these basic concepts forge a strong bridge between philosophical and spiritual interests and their intrinsic interconnectedness.

Here are some examples regarding the anthropological interests. Cantone is searching for 'a philosophy of spiritual life' and tries to disclose the 'metaphysical root of religious experience'. Spiritual life is basically a single experience of love, a love circle with three dialectical moments: Eros, Logos, and Agape. ${ }^{117}$ Zweerman considers the 'vulnerability' fundamental for a viable spirituality. ${ }^{118}$ Levinas shows how the 'Infinite' is an immediate wounding of the human subjectivity. ${ }^{119}$ Berger points at 'attention', connecting mysticism and metaphysics. ${ }^{120}$

Regarding the basic structure of human rationality, philosophy is particularly interested in theoretical questions about the different forms of knowledge such

${ }^{114}$ E. Wolz-Gottwald, Transformation der Phänomenologie: Zur Mystik bei Husserl und Heidegger, Wien 1999; R. Elberfeld, Phänomenologie der Zeit im Buddhismus: Methoden interkulturellen Philosophierens, Stuttgart-Bad Cann Stadt 2004.

115 See for example S. King, 'Two epistemological models for the interpretation of mysticism', in: Journal of the American Academy of Religion 56 (1988), 257-279; D. MacKinnon, 'Some epistemological reflections on mystical experience', in: Mysticism and philosophical analysis, 132-140.

116 W. Dupré, Experience and religion: Configurations and perspectives, Brussels 2005; Wendel, Affektiv und inkarniert; E. Tugendhat, Egozentrizität und Mystik: Eine anthropologische Studie, München 2003.

117 C. Cantone, 'Per una filosofia della vita spirituale: Alle radice metafisiche dell'esperienza religiosa', in: Salesianum 51 (1989), 515-522.

118 Th. Zweerman, Om de eer van de mens: Verkenningen op het grensvlak van filosofie en spiritualiteit, Delft 1993.

${ }^{119}$ E. Levinas, Of God who comes to mind, Stanford (CA) 1998.

${ }^{120}$ H. Berger, Werkelijkheid, aandacht en mystiek, Budel 2006. 
as insight, faith, belief, experience, intuition, consciousness, knowledge, etc. ${ }^{121}$ In premodern philosophy, theoria, gnosis, speculatio, contemplatio, visio and the like belonged to the standard repertory of philosophy. ${ }^{122}$ They are still important for the actual spiritual philosophy.

Professions. Practical philosophy seems to point into three directions.

The first kind of reflection investigates the conditions needed for spirituality and philosophy. Thus in antiquity philosophers were convinced that clear thinking presupposes a degree of asceticism: the cultivation of virtue, food restrictions, and control of one's drive. ${ }^{123}$ In his book Spirituality, Diversion and Decadence, Peter van Ness investigates ascetic practices (prayer, fasting, meditation, solitude) from a philosophical angle, arguing that spiritual practioners operate in antagonism with social forces inducing behaviour that is controllable, addictive and deadly. ${ }^{124}$ John Cottingham brings together affective and intellectual aspects of human experience, and practical as well as theoretical concerns. The spiritual dimension of life is not dependent on an isolated set of contents and convictions, but is inseparable from a search for self-understanding and moral growth, in the context of an asceticism of the spirit. ${ }^{125}$ An interesting paradigm of such a practice oriented view on the life of a thinker is Edith Stein: A Philosophical Prologue. ${ }^{126}$ The preoccupation of Macintyre is the relationship between philosophical thinking and the personal and cultural context of an individual's life, in this case of a spiritual life.

In a second kind of reflection spiritual practices are considered as paradigms, giving to think. Philosophers reflecting on spiritual practices shed a new light on the phenomenon of spirituality. It offers an important contribution in thinking spirituality from the viewpoint of practice, for instance the Holocaust experience, the phenomenon of the saint, and so on. ${ }^{127}$

${ }^{121}$ Albert, Einführung in die philosophische Mystik; Mysticism and philosophical analysis (Ed. S. Katz); S. Payne, John of the Cross and the cognitive value of mysticism: An analysis of San Juanist teaching and its philosophical implications for contemporary discussions of mystical experience, DordrechtBoston-London 1990; D. Turner, The darkness of God, Cambridge 1995; The innate capacity (Ed. R. Forman); J. Decorte, Raak me niet aan: Over Middeleeuws en postmiddeleeuws transcendentiedenken, Kapellen-Kampen 2001; L. Dupré, Ein tieferes Leben: Die mystische Erfahrung des Glaubens, Freiburg 2003.

122 J. Ritter, Metaphysik und Politik, Frankfurt a.M. 2003 (Neuausgabe).

123 P. Hadot, Philosophy as a way of life, Cambridge (MA) 1995.

${ }_{124}$ P. van Ness, Spirituality, diversion and decadence, Albany 1992.

125 J. Cottingham, The spiritual dimension, philosophy, and human value, Cambridge 2005.

126 A. MacIntyre, Edith Stein: A philosophical prologue (1913-1922), Lanham (MD) 2006.

${ }_{127}$ M. Baird, On the side of the angels: Ethics and post-Holocaust spirituality, Leuven 2002;

E. Wyschogrod, Saints and postmodernism: Revisioning moral philosophy, Chicago 1990. 
A third kind of reflection is concerned with the inner dynamics of spiritual practices itself: philosophical criteriologies related to exercises, prayer, and so on. ${ }^{128}$

Words. Philosophers are inclined to reflect on basic concepts, such as unity, truth, ein-soph, essence, and so on. ${ }^{129}$ Particularly in phenomenology philosophers developed a feeling for the function of basic words, which point to fundamental realities, and, in pointing them out, bring them to the light. ${ }^{130}$ Martin Heidegger puts it this way: in its original way the language of praxis gives an account of a given understanding of lived experience. ${ }^{131}$

In the numerous philosophical dictionaries and lexicons one may find words of the spiritual repertory: anima, cognitio, unio, contemplatio, visio, etc. They are waiting to be brought together into a spiritual-philosophical lexicon. Sometimes a monography is dedicated to a single word or concept. In his study on boredom, philosophically deepened by Schopenhauer, Kierkegaard, Nietzsche and Heidegger, Van de Camp connects this subject with the acedia experience of spirituality. In this perspective he made a semantic study on acedia. ${ }^{132}$ Paradigmatic is the study Gelàzenheit und Abegeschiedenheit of Panzig. ${ }^{133}$ In this dissertation the author carefully analyses the meaning of two key words in the mystical-philosophical works of Meister Eckhart. Within the biographical and literary-historical framework the development of these two terms is described.

Things. Although in philosophy a rather broad tradition reflects on the material basis and implications of life in general (see for instance all kinds of cosmology) and more specifically of human life (see for instance all kinds of political philosophy) $)^{134}$ and it is quite familiar in philosophy to reflect on subjects as economic structures, social structures, power structures, power mechanisms, Marxism, materialism, and so on, however, till now no philosopher has systematically

128 O. Bollnow, Vom Geist der Übung, Stäfa 1993 (3rd ed.); B. Caspar, Das Ereignis des Betens, München 1998; A. Wucherer-Huldenfeld, Ursprüngliche Erfahrung und personales Sein. Ausgewählte philosophische Studien, Band 1: Anthropologie-Freud-Religionskritiek, Wien 2003 (2nd ed.); Band 2: Atheismusforschung, Ontologie und philosophische Theologie, Religionsphilosophie, Wien 1997; N. Luhmann \& P. Fuchs, Reden und Schweigen, Frankfurt a.M. 1989.

129 See for instance Albert, Einführung in die philosophische Mystik, 71-147. See also Baier, 'Spiritualitätsforschung heute', 18.

${ }^{130}$ C. van Peursen, Verhaal en werkelijkheid: Een deiktische ontologie. Kampen-Kapellen 1992.

131 M. Heidegger, Being and time, London 1962, 138-203.

${ }^{132}$ L. van de Camp, De kracht van de leegte, Nijmegen 1992.

133 E. Panzig, Gelàzenheit und Abegeschiedenheit: Einführung in das theologische Denken des Meister Eckhart, Leipzig 2003.

${ }^{134}$ L. McWhorter, 'Foucault's political spirituality', in: Philosophy Today 47 (2003), 39-44;

L. Bauckaert, 'Spirituality as a public affair', in: Ethical Perspectives 10 (2003) no.2, 106-117. 
analysed spirituality from this specific perspective. Maybe, spirituality is already categorically thought as 'spiritual', the opposite pole of 'infrastructure'.

Perhaps from four directions the material culture of spirituality can be approached philosophically. A first bridge could be a reconsideration of the mind-body or spirit-material schemes. ${ }^{135} \mathrm{~A}$ second bridge: a reconsideration of cosmology from the viewpoint of eco-philosophy. ${ }^{136}$ The third bridge could be an evaluation of Marxist and neomarxist tendencies regarding the phenomenon of spirituality ${ }^{137}$. The last bridge: a critical integration of postmodern studies, interested in the material culture of particular traditions.

Images. In modern culture aesthetics is the branch of philosophy concerned with the nature of art. Gottlieb Baumgarten (1714-1762) coined the term 'aesthetics', referring to a philosophy of 'sensory cognition' dealing with basic questions such as: what does constitute beauty, ugliness, sublime etc.? What are criteria for an artistic judgement?

For ancient Greeks and later philosophies, inspired by this tradition, beauty, not restricted to aesthetics, was intrinsically linked with goodness and morality, with truth and rationality, with measure and mathematics. The dimension of beauty is classically defined by proportion, integrity, and radiance of form. At the same time it gives delight in the very act of its being perceived. Kant, the leading philosopher of modern aesthetics, limited aesthetics to the sphere of pure beauty and taste, in relation with symbol and imagination, but separated from truth and morality, let alone holiness. Taste is subjective, dealing with qualities that happen to please us. Unfortunately, this modern approach to aesthetics made it difficult to see any connection with spirituality. ${ }^{138}$

Later aesthetics created some openness providing possibilities for a relation between philosophy, spirituality, and art. Three points are promising.

First, a hermeneutical attitude toward art has grown. For Heidegger, art was basic for philosophy. Gadamer developed a hermeneutic vision on art. This paved the way for a new understanding of art, promising for the relation between aesthetics and spirituality. 139

135 D. Carr, 'Metaphysics, reductionism, and spiritual discourse', in: Zygon 32 (2002), 491-509.

136 F. Soontiens, Natuurfilosofie en milieuethiek, Amsterdam 1993; A. Booth, Learning to walk in beauty: Critical comparisons in ecophilosphy focussing on bioregionalism, Madison 1992; A. Naess, Ecology, community and lifestyle, New York 1991.

137 A. McKnight, 'Reevaluating Marx and spirituality: Emancipation and the search for meaning', in: Journal of Thought 40 (2005) no.1, 61-78.

138 Sacred interconnections: Postmodern spirituality, political economy, and art (Ed. D. Griffin), Albany 1990.

139 F. Brughetti, Estetica espiritual, Buenos Aires 1991. 
Second, theorists acknowledged that artistic forms shape perceptions related to life. An artistic form, although enclosed in itself and unique, is at the same time superfluous to larger human interests. Artistic forms, capable to relate emotions, invite the participants into a process of interaction. ${ }^{140}$

Third, art has to be seen as a form of culture that is rich in spiritual vitality and imaginative depth, addressing and engaging the participant wholly. Art mediates intensive relations to the self, the nature and the Divine, evoking awed respect for the sublime and holy, and initiating into spiritual vitality and imaginative depth. ${ }^{141}$

Texts. Philosophy has influenced spirituality fundamentally on the level of 'texts', particularly by putting questions on the constitution of texts and by reflecting on hermeneutics. Sometimes also an exegesis of spiritual texts has been performed.

It was Paul Ricoeur who pointed at the 'spirituality' of texts as such. Precisely, the constitutive moments of a text unfold its spirituality: the externalisation in external signs which alienates the writing from its author is the mark of its spirituality'; ${ }^{142}$ 'the spirituality of discourse manifests itself through writing, which frees us from the visibility and limitation of situation by opening up a world for us, that is, new dimensions of our being-in-the world'; 143 'instead of being addressed just to you, the second person, what is written is addressed to the audience that it itself creates. This again, marks the spirituality of the writing. ${ }^{144}$ Precisely, the moment a text is freed from its author, its addressee, and its context, its 'spirituality' unfolds itself.

On the level of hermeneutics, the influence of philosophers like Heidegger and Gadamer is enormous. Particularly the involvement of the reader in the text is an important dimension, opened up by philosophers. Very useful for the understanding of spiritual reading strategies is Wolfgang Iser's The Act of Reading, a phenomenological description of reading: by reading the text we are in the text and the text is in us. ${ }^{145}$

${ }^{140} \mathrm{P}$. Thayer, The experience of being creative as a spiritual practice: A hermeneutic-phenomenological study, New York 2003.

${ }^{141}$ F. Brown, Religious aesthetics, Princeton 1989; Neglected wells: Spirituality and the arts (Ed. A. Murphy \& E. Cassidy), Blackrock-Dublin 1997; P. Moyaert, Iconen en beeldverering: Godsdienst als symbolische praktijk, Amsterdam 2007.

${ }^{142}$ P. Ricoeur, 'The model of the text: Meaningful action considered as a text', in: Idem., From text to action: Essays in hermeneutics II, Evanston 1991, 150.

143 Ibid., 149.

144 Ibid., 150.

145 W. Iser, The act of reading, Baltimore-London 1978. 
A groundbreaking study for the study of spirituality is Beyond the Verse of Emmanuel Levinas. His thesis is, 'that language, at the hour of its ethical truth - that is, of its full significance - is inspired, that it therefore can say more that it says, and that prophecy is thus not an act of genius, but the spirituality of the spirit expressing itself, the ability of human speech to extend beyond the primary intentions that carry it'. ${ }^{146}$ Writings reveal their spirituality at the moment they touch - from beyond the verse - the receptive reader. ${ }^{147}$

Important hermeneutical insights about mystical paradigms of negative language offered Jacques Derrida in his Psychè: Inventions de l'Autre.

An example of a philosophical reading of a key text in Western spirituality is the exegesis of De theologica mystica by Ben Schomakers. ${ }^{148}$

Histories. The attention that philosophy paid for the historical dimension of spirituality has different levels.

Many studies are dedicated to philosophers who were masters in spirituality as well: Thomas Aquinas, Maimonides, Al-Ghazali, Anselm of Canterbury, Hugo of St. Victor, Albert the Great, Bonaventura, Duns Scotus, Nicolas of Cues, and others. ${ }^{149}$ Also mystics (Eckhart, Ruusbroec and others) who exerted influence on philosophers (Spinoza, Descartes, Hegel, Heidegger and others) are studied. ${ }^{150}$ Sometimes the problem of historicity related to spirituality is thematized. ${ }^{151}$ The most important contributions of philosophy in the field of history of spirituality are studies focussing on important themes or clusters of themes. In his study The Darkness of God, Denys Turner investigates the basic structure of mystical knowledge since Plato, Gregory of Nyssa, Augustine, Denys the Areopagite, Bonaventura, Eckhart, The Cloud of Unknowing, Denys the Cartusian and John of the Cross. He finds this basic structure in apophatic discourse

\footnotetext{
${ }^{146}$ E. Levinas, Beyond the verse, Bloomington-Indianapolis 1994, 114.

147 K. Waaijman, Tegendraads lezen, Kampen $2006^{2}$.

148 Pseudo-Dionysius Areopagita, Over mystieke theologie (trans. \& ed. Ben Schomakers), Kampen 1998.

${ }^{149}$ To give just a few examples: M. Johnston, The spiritual logic of Ramon Llull, Oxford 1987; A. Koyré, La philosophie de Jacob Boehme, Paris 1929; Albert the Great (F. Kovach \& R. Shahan), Norwan 1980; M. Pohlenz, Die Stoa: Geschichte einer geistigen Bewegung, Göttingen 1948-49; A. Weeks, Boehme: An intellectual biography of the seventeenth century philosopher and mystic, New York 1991. Blumenthal wrote a monography on Maimonides and Hoter ben Shelomo: D. Blumenthal, Philosophical mysticism: Studies in rational religion, Ramat Gan 2006.

${ }^{150}$ Gregor von Nyssa und die Philosophie (H. Dörrie e.a.), Leiden 1976; K. Goldammer, Paracelsus in neuen Horizonten, Wiesbaden 1986; J. Caputo, The mystical element in Heidegger's thought, New York 1986; A. Coudert, Leibnitz and the Kabbalah, Dordrecht-London 1995.

151 See for instance M. Botting, Spirituality and time, Cambridge 1997.
} 
(beyond all affirmations and negations) and the apophatic subject (beyond all definitions and negations of the self). ${ }^{152}$ These structures should be distinguished from 'mystical experience' as modern period interprets this tradition. An other groundbreaking study is Schmidt-Biggemann's Historische Umrisse abendländischer Spiritualität in Antike, Mittelalter und Früher Neuzeit. ${ }^{153}$ In this philosophical history the most important and most influential thought structures of Western spirituality are documented and analysed in their historical origins and developments. But also a critical analysis of contemporary spirituality - of course in a historical perspective - is important. ${ }^{154}$

These groundbreaking studies provide a fundament for further systematic research in the field of history of spirituality, from a philosophical perspective. ${ }^{155}$

Processes. First of all, philosophy does not only offer insights in spiritual processes, it can also be considered as a spiritual process in itself. In this way the Cartesian Meditations can be understood as a spiritual exercise. ${ }^{156}$ Perhaps, philosophy is essentially a spiritual exercise, as Pierre Hadot argues? ${ }^{157}$ Spirituality and philosophy can be seen as ways leading to an ontological awareness and a cosmic consciousness, as parts of the inexhaustible process of concealment-and-disclosure, inspired by the thirst of life truth. ${ }^{158}$ In spiritual processes, we may distinguish structure, direction, and dynamics.

152 Turner, The darkness of God. See also D. Duclow, Masters of learned ignorance: Eriugena, Eckhart, Cusanus, Aldershot; Burlington (VT) 2006.

153 W. Schmidt-Biggemann, Historische Umrisse abendländischer Spiritualität in Antike, Mittelalter und Früher Neuzeit, Frankfurt a.M. 1998.

${ }^{154}$ E. Rungaldier, Philosophie der Esoterik, Stuttgart 1996; W. Hanegraaff, New Age religion and Western culture: Esotericism in the mirror of secular thought, Leiden 1996.

155 See K. Neumann, Natura sagax, die geistige Natur: Zum Zusammenhang von Naturphilosophie und Mystik in der frühen Neuzeit am Beispiel Johann Arndts, (?) Tübingen 2004. See also: Gnosis und Mystik in der Geschichte der Philosophie (Ed. P. Koslowski), Zürich 1988; W. Göbel, Der Wille zu Gott und das Handeln in der Welt, Freiburg-Wien 1993.

156 E. McGushin, 'Foucault's Cartesian Meditations', in: International Philosophical Quarterly 45 (2005) no.1, 41-59.

157 P. Hadot, Exercises spirituels et philosophie antique, Paris 1981; W. Schmid, Philosophie der Lebenskunst: Eine Grundlegung, Frankfurt a.M. 1999. See also G. Böhme, Einführung in die Philosophie: Weltweisheit, Lebensform, Wissenschaft, Frankfurt a.M. 1994; R. Shusterman, Philosophie als Lebenspraxis, Berlin 2001.

${ }^{158}$ K. van der Wal, 'Filosofie en spiritualiteit: Hernieuwde aandacht voor een oorspronkelijke betrekking', in: Tijdschrift voor Filosofie 64 (2001) no.1, 3-25; O. Duintjer, 'Over het primaat van de waarheid als "openbaarwordingsgebeuren"', in: Ibid., 27-45; G. Visser, 'Of er van buitenaf iets op de muur tikt: Een situering van het werk van Otto Duintjer, in: Ibid., 47-70. 
In early Christian spirituality, the Nicomachean Ethics of Aristotle was important. It provided the main principle of structuring spiritual transformation: the difference between the programmatic intent (skopos) and the end goal of contemplation (telos), as we can see in the Conferences of Cassian. Spiritual processes need orientation and direction. In this point, research has been done by Dietmar Mieth, studying Eckhart, and philosophers inspired by the ethical appeal in the works of Levinas. ${ }^{159}$

Relationships. After a number of starts in the nineteenth century (Schleiermacher, Jacobi, Feuerbach, Simmel) and the development of a number of motifs in phenomenology (intersubjectivity, empathy, 'alter ego', sympathy and the like) ${ }^{160}$ dialogical thinking broke through after World War I, a response to the shocking experience of this cruel conflict, which was the result of ethnocentrism, absolutized autonomy, and nationalism. 'The new thought' expressed itself in a number of works like Religion der Vernunft aus den Quellen des Judentums (1917/18) by Cohen, Stern der Erlösung (1921) by Rosenzweig, Das Wort und die geistigen Realitäten (1921) by Ebner, Ich und Du (1923) by Buber, and so forth. ${ }^{161}$ Some of these works are considered to be mystical writings. Star of Redemption by Franz Rosenzweig 162 is called 'mystical in the strictest sense' by Gershom Scholem. ${ }^{163}$ The same can be said about $I$ and Thou by Martin Buber. ${ }^{164}$

This dialogical orientation was reinforced and radicalized by the experiences of World War II, which undeniable carried over into the work of the Jewish thinker Emmanuel Levinas. His main work Totality and Infinity ${ }^{165}$ shows how the field of interiority unfolds itself as dwelling place, 'open to the Other'. ${ }^{166}$

159 Baird, On the side of the angels; Wyschogrod, Saints and postmodernism; L. Walker, 'Religion, spirituality: The value of saintliness', in: Journal of Moral Education 32 (2003) no.4, 373-384.

160 Zur Geschichte des Dialogs (Ed. M. Meyer), Darmstadt 2006; H. Schrey, Dialogisches Denken, Darmstadt 1983. For the phenomenology see E. Husserl, Zur Phänomenologie der Intersubjektivität II (Hua XIV), The Hague 1973; E. Stein, On the problem of empathy, The Hague 1964.

${ }^{161}$ H. Herrigel, Das neue Denken, Berlin 1928; F. Rosenzweig, Kleinere Schriften, Berlin 1937, 373-398.

162 F. Rosenzweig, Star of redemption, New York-Chicago-San Francisco 1971.

163 'On the 1930 edition of Rosenzweig's Star of Redemption', in: G. Scholem, The Messianic Idea in Judaism, and other essays on Jewish spirituality, New York 1974, 320-324.

164 See K. Waaijman, De mystiek van ik en jij: Een nieuwe vertaling van 'Ich und Du' van Martin Buber met inleiding en uitleg en een doordenking van het systeem dat eraan ten grondslag ligt, Kampen 1991.

165 E. Levinas, Totality and infinity, Pittsburgh 1969.

166 Ibid., 172. 
From another perspective the same relationality, as a universal spiritual category, can be thematized by rethinking the Ars Conjecturalis of Nicolas of Cusa. ${ }^{167}$

\section{SPIRITUALITY AND LiteraRY SCIENCE}

All spiritualities have their traditions, whether transmitted orally or in writing: sacred scriptures, ritual texts, rules, spiritual biographies, mystical texts, spiritual writings, treatises, and so forth. As a rule these texts are gathered up in collections and on places treated with special care and respect.

Spiritualities provide their practioners not only by texts, but also by reading procedures, fostering the transformative impact of these texts. They develop ways of understanding and appropriation.

From a linguistic and literary point of view, scholars are, already for decades, studying spiritual writings: providing text-critical editions, dictionaries of spiritual language, scientific interpretations, and hermeneutic reflections. ${ }^{168}$

Disciplines. In his search for a definition of mysticism Joseph Dan states: 'It seems that the adjective "mystical" is used by scholars studying religion mainly in two different contexts: when describing the character of a text or portion of a text, and when describing a historical religious phenomenon, a movement, a group, or the work of a religious thinker'. ${ }^{169}$ Dan correctly distinguishes the linguistic approach from the historical perspective. A literary approach of texts calls for a specific modus operandi. In text-research we are dealing with the constitution, description, interpretation and pragmatics of linguistical utterances with a view to the experience conveyed in them.

From the $12^{\text {th }}$ century, when mystical literature and theology gradually discovered their own way, the interest in spiritual language has increased, from the $15^{\text {th }}$ century on and named as 'mysticism'. ${ }^{170}$ In the $17^{\text {th }}$ century Sandaeus wrote his Pro theologia mystica clavis. ${ }^{171}$ The last two centuries the language of mysticism became an intriguing object of study for literary criticism.

167 I. Bocken, Waarheid en interpretatie: Perspectieven op het conjecturele denken van Nicolaus Cusanus 1401-1464, Maastricht 2002; Idem, De kunst van het verzamelen: Historisch-ethische inleiding in de conjecturele hermeneutiek van Nicolaus Cusanus, Budel 2004; Idem, 'Inleiding', in: M. Buber, De geschiedenis van het moderne individu, Kampen 2005, 7-47.

168 R. Faesen, 'Mystiek en filologie', in: Encyclopedie van de mystiek, 285-289; H. Blommestijn \& F. Maas, 'Mystiek en taal', in: Ibid., 290-301; J. Gledhill, 'Literature and spirituality', in: The new SCM dictionary of Christian spirituality, 409-412.

169 J. Dan, 'In quest of a historical definition of mysticism', in: Studies in Spirituality 3 (1993), 59.

170 M. de Certeau, La fable mystique: XVIe-XVIIe siècle, Paris 1982.

${ }^{171}$ M. Sandaeus, Pro theologia mystica clavis, Heverlee 1963 (Orig. Coloniae Agrippinae 1640). 
Looking back, one may notice that the relation between spirituality and literary sciences is played out on several levels, unfolding the different levels of meaning implemented in linguistic utterances: research on the genesis of manuscripts and editions and their reception, on behalf of the constitution of a critical text; literary research on the level of form, style, imagery and structure; intertextual relations; lexicological research; and pragmatics. ${ }^{172}$

An important aspect of literary research is the relation between significant-signifié in mystical language: the trace of the immediate and passive experience of God's presence in the mystical language itself. Brémond saw an analogy between poetry and mysticism. ${ }^{173}$ Nelson described 'the rhetoric of the ineffable'. ${ }^{174}$ Van de Watering proposed to describe the mystical repertory, 'a lexicon of specific forms and means of expression: imagery, representations, style figures, procedures'. ${ }^{175}$ The last decades precisely this field of tension between language and the mystical process has been studied extensively. ${ }^{176}$

Theories. From the $18^{\text {th }}$ century on, in reaction to the fragmentation into special hermeneutics, the study of general hermeneutics was launched. It was Friedrich Schleiermacher who raised the question concerning the possibility of and conditions for understanding (Verstehen) as such. The development of hermeneutics, very important for the study of spirituality, has resulted in a flood of literature. ${ }^{177}$ On four points the hermeneutics has made a fundamental contribution to the study of spirituality.

Firstly, writing is a process of fixation: a graphic sign is fixed on a more or less durable material. This process leaves behind a number of open spaces: where the writing frees itself from the author; where the formative context withdraws itself from the text; where the people addressed withdraw itself from the text, and so forth. They are 'signs of spirituality'. ${ }^{178}$

\footnotetext{
${ }^{172}$ For a paradigm of a recent literary study from different perspectives see L. Swart, De articulatie van de mystieke omvorming in 'die geestelike Brulocht' van Jan van Ruusbroec, Nijmegen 2006.

${ }^{173}$ H. Brémond, Prière et poésie, Paris 1926.

${ }^{174}$ L. Nelson, 'The rhetoric of the ineffability: Toward a definition of mystical poetry', in: Comparative Literature 8 (1956), 323-336.

175 C. van de Watering, Met de ogen dicht: Een interpreatatie van enkele gedichten van Lucebert als toegang tot diens poëzie en poetica, Muiderberg 1979.

176 See C. van Acht, Mystieke poëzie, poëtische mystiek, Nijmegen 1982; A. Dhar, Mysticism in literature, New Delhi 1985; A. Haas, Mystik als Aussage: Erfahrungs-, Denk- und Redeformen christlicher Mystik, Frankfurt a.M. 1996; Mysticism and language (Ed. S. Katz), New York etc. 1992; Poésie et mystique (Ed. P. Plouvier), Paris 1995; M. Sells, Mystical languages of unsaying, Chicago etc. 1994.

177 A. Thiselton, New horizons in hermeneutics, London 1992, 621-661; J. Grondin, Einführung in die philosophische Hermeneutik, Darmstadt 1991, 185-246.

178 P. Ricoeur, From text to action, Evanston 1991, 149-150.
} 
Secondly, reading is a process, in which the reader and the text are transformed in each other. This transformation is caused by activities of the reader which are indispensable: continually recapturing the successive text segments backward and forward; passing through the different roles and positions, presented by the text; imagening the imaginary world by portraying it to himself. The reader, as long as he really performs the text, receives the meaning of the text by composing it. ${ }^{179}$

Thirdly, the understanding of a text is constituted by two movements. The first movement is that of the tradition which as a result of temporal distance presents itself as being opposite and strange. The second movement is that of the interpreter who anticipates the meaning which governs his understanding of the text. Understanding is the fusion of these horizons. ${ }^{180}$

Fourthly, the understanding of the spiritual pragmatics of a text, particularly of a sacred text. Against the background of the Jewish reading praxis (pardes) Emmanuel Levinas outlines four fields of meaning 'beyond' the clearly defined verses: the enigmatic meaning, implied in the obvious one: the prophetic dignity of the language, listening to its own utterance; the coordination to the other; and the uniqueness of the reader, coming to the fore in his responsibility. ${ }^{181}$

These hermeneutical insights are a challenge for the study of spirituality, interdisciplinarily connected with the literary science. The challenge is to integrate these insights in a design of spiritual hermeneutics. ${ }^{182}$

Professions. Texts are connected with specific competencies and roles. In traditional cultures writers or poets are supposed to be inspired by God. If a culture is interested in a careful tradition of its sacred texts, the role of the 'scribe' is surrounded by specific spiritual rituals, like in Jewish spirituality. Particularly calligraphy can be a spiritual exercise. ${ }^{183}$ In liturgy the role of the 'lector' has its specific place. In all these examples texts are evoking specific roles and competencies.

In modern times the 'exegete' has created a distinct profile for himself. His role was strongly focussed on the true content of the text, in this case the biblical text. Particularly in the protestant tradition this role concept was an essential element in worship and ministry.

\footnotetext{
${ }^{179}$ Iser, The act of reading.

${ }^{180}$ H. Gadamer, Truth and method, New York 1991.

${ }^{181}$ Levinas, Beyond the verse.

182 See, for instance, M. Oeming, Biblische Hermeneutik: Eine Einführung, Darmstadt 1998; Waaijman, Spirituality, 729-773.

183 D. Hartley, Spirituality explored with the help of calligraphy, Leek 1993; A. Schimmel, Calligraphy and Islamic culture, New York 1984.
} 
In recent times, Scripture is understood as a centre of faith communication: bringing people together around the Scripture, facilitating them for reading and interpreting the Bible as a community, providing a space for the search of meaning and encountering the Word of God. ${ }^{184}$ For this practice the role of a coach is needed, facilitating the community for a spiritual process. This facilitator should, of course, have some insights in the content, the background and the composition of the text. But most of all he or she should be equipped with the competency of listening and empathy, so that the reading community comes in contact with the Word of God, on a level of experience. ${ }^{185}$

Words. From a literary perspective words unfold their meaning as a complex system of denotative and connotative signals. Semantic research tries to decipher this complex reality.

Denotative meanings are studied in semantic research, resulting in etymology and description of the basic meaning. The word 'spirituality', for instance, refers to the area of 'spirit': the spirit of God and/or the spirit of man. The range of this category is enormous, including the movement of the spirit (ruach) and the inner dimension of the mind (nous). Etymology in lived spirituality has the tendency to isolate itself from intertextual, co-textual and contextual meanings. Therefore the study of spirituality has to be critical on this point.

Connotative meaning unfolds itself in a network of textual relationships. In the first place this meaning is produced by the direct co-text in which a word is used. Spiritual keywords like union with God, desert, prayer, soul, dark night etc. are to be read, again and again, from these direct co-texts in which they are used. For the meaning of a word within the works of a writer concordantic research remains indispensable. A second source of connotative meaning is the rich network of intertextual relationships and strategies: participation which seeks to keep texts alive by quotation, repetition, imitation, surpassing, fending off or destroying earlier texts; transformation which plays with and uses unfamiliar texts. To mention only one example, words in Jewish mystical texts are ununderstandable without the continuous presence of the Torah at the background. ${ }^{186}$

${ }^{184}$ E. Bianchi, God ontmoeten in zijn Woord: Inleiding tot de 'lectio divina', Brugge-Zeist 1991; K. Daiber \& I. Lukatis, Bibelfrömmigkeit als Gestalt gelebter Religion, Bielefeld 1991; M. Guinan, To be human before God: Insights from biblical spirituality, Collegeville 1994; T. Hall, Too deep for words: Rediscovering lectio divina, New York 1988; C. Mesters, Defenseless flower: A new reading of the Bible, New York 1989; P. Toon, The art of meditating on Scripture: Understanding your faith, renewing your mind, knowing your God, Grand Rapids 1993.

185 S. Brown, Text and psyche: Experiencing Scripture today, London 1998.

186 G. Scholem, Judaica: Studien zur jüdischen Mystik 3, Frankfurt a.M. 1981; J. Kugel, Prayers that cite Scripture, London 2006. 
Lexicological research, except some excellent studies, ${ }^{187}$ looks for further development. ${ }^{188}$

Things. We can materially define a text as 'texture': an external fabric that is visual, auditive or tactile in nature. A visual fabric is optically so structured that the signs, differing in shape (handwriting, print etc.), colour combination (black-white, coulored etc.) and arrangement (page design, image area etc), manifest themselves against a background of stone, wood, iron, papyrus, parchment, textile, paper or screen. An auditive textual fabric is acoustically so shaped that signs manifest themselves in sound (alliteration, assonance, rhyme etc.) and performance (solo, choir, etc.), against a background of relative silence. A tactile fabric demarcates itself by way of rises and dips, a more or less even background.

Written texts are made available by an agency (publishing company, print shop, book store etc.) or in public institutions (library, archives, etc.). Particularly the ways scrolls are written, books are edited and preserved, pages are illuminated, are important signs of spirituality. The study of spirituality has not paid systematic attention to the material dimensions of the literary traditions of texts.

Images. From the time on that spirituality and mysticism were challenged to develop their own language on behalf of the articulation of the process of spiritual transformation, the best of their representatives used their language in an excellent way. They were exceptionally creative in forging the language appropriate for the unique character of their experience. To mention only Eckhart and Hadewych, Ruusbroec and John of the Cross. Four aspects are to be mentioned in the field of art and literature.

First, the aspect of form. A literary approach profiles in sources of spirituality their narrative beauty, their poetical splendour, their dramatic potential and their metaphysical depth. Thus, a sharpened eye will discover also the mystical dimension in poems. ${ }^{189}$

Second, the relation with language. On the one hand all literature speaks of the human condition and therefore touches on its spiritual dimension. Spiritual persons speak the same language as other people. On the other hand, spirituality creates its own alternative modes of language, each of which needs a grammar of

187 See, for instance, the paradigmatic study of J. Alaerts, La terminologie essentielle dans l'oeuvre de Jan de Ruusbroec (1293-1381), Lille 1973.

188 See Faesen, 'Mystiek en filologie', 285-286.

${ }^{189}$ H. van den Doel, Zingen als een gek: Het verschijnsel Gerrit Achterberg, als mens met een handicap, dichter en mysticus, Culemborg 1995; J. Oegema, Lucebert, mysticus: Over de roepingsgedichten en de 'Open brief aan Bertus Aafjes', Nijmegen 1999. 
its own. ${ }^{190}$ It is precisely in the inbetween of the tension of both, that the relation with the 'Inexpressible' expresses itself. ${ }^{191}$

Third, the imagery. Spiritual writers use images and metaphors. Ruusbroec uses the metaphor of the mirror to show spiritual reality, and how it works. ${ }^{192}$ Images reveal sometimes the depth-structure of the mystical process. ${ }^{193}$ Tensions in the imagery of Ephrem the Syriac represent poetically the tensions and transitions of the spiritual way. ${ }^{194}$ It is that these images, symbols and metaphors do not illustrate an idea or theology but express and interpret a spiritual experience.

Fourth, the imaginative power. Every written text captivates the reader as long as she or he really reads. ${ }^{195}$ The reader gives shape to the representation of the text, in his imagination. Reading occurs 'in the mode of the image'. Reading is 'aesthetic'. The reader participates 'affectively' in the text. ${ }^{196}$ The reader is 'bodily' transformed by the acoustic, optical, tactile, and sensory-motorical qualities of the text, a transformation in which the spiritual transformation, incarnated in the text, is transferred in the reader.

Texts. At the centre of the interdisciplinarity of literary sciences and spirituality is the corpus of spiritual texts. This corpus contains different genres: sacred texts and the meditations and interpretations dedicated to them; ritual texts, and again the track of commentaries behind them; rules and constitutions of communities of dedicated life; biographies and autobiographies; mystical texts and their interpretations; spiritual writings as nourishment for the spiritual life; treatises providing some blueprint of the spiritual way. These genres ask for an appropriate interpretation.

Apart from the genre differences, spiritual texts, as all texts, need a truthful presentation: the material object for literary-spiritual reflection. A 'text' is a 'thing', a sequence of signs contrasting with a background. This contrast makes the signs readable. This simple fact implies a whole 'material culture'.

${ }^{190}$ E. Ribbat, 'Aussagen des Unsagbaren in der Literatur', in: Der Christ der Zukunft: Ein Mystiker (Ed. P. Gordan), Salzburg 1991, 210-219.

${ }^{191}$ M. de Certeau, 'L'énonciation mystique', in: Recherches de Science Religieuse 64 (1976), 183215.

192 V. Schulz-Zellmann, 'Zur Spiegelmetaphor im Werk des Jan van Ruusbroec', in: Ons Geestelijk Erf 57 (1983), 248-269.

${ }^{193}$ H. Noë, In een verwonderen van al deser rijckeit: Het beeldgebruik in Jan Van Ruusbroecs Dat rijcke der ghelieven, Leuven 2001.

${ }^{194}$ K. den Biesen, Eenvoudig en stoutmoedig: De kunst van het symbolisch denken volgens Efrem de Syriër, Nijmegen 2006.

195 Iser, The act of reading.

196 Ibid., 131, 135 and 157. 
In lived spirituality texts serve the interest of edification. Often the first publishers were simultaneously interpreters who sought to escape condemnation from the side of orthodoxy. Not infrequently they were also members of the socalled 'second generation', who felt duty-bound to routinize the original experience.

From Migne onward, editors attempted to produce critical editions of the sources of spirituality. In the $20^{\text {th }}$ century important text-critical editions were provided, whether in a series (e.g. Sources Chrétiennes or Corpus Christianorum) or apart from a series (e.g Bernard of Clairvaux, Meister Eckhart, and Teresa of Avila).

As a rule text-critical editions limit themselves to the reconstruction of the socalled authentic text: the text that is as close as possible to the texture provided by the author him- or herself. Recent text-editorial insights define the critical texts more broadly, covering the entire life of the text-tradition in the field of tension constituted by the author, editor, copyist and printer, as well as by the public's reception, in short, the entire history of the manuscript. ${ }^{197}$

Texts are not exclusively a 'thing' in front of the reader, 'material object', detached from the reader. 'Within the framework of a phenomenologically-oriented aesthetic the literary text is to be regarded as the combined action of operative structures which are interrelated and which the reader actualizes in reading it in order to generate the meaning via the play of shifting schemata'. ${ }^{198}$ In these operative structures four fields of tension are important, providing an architecture in which the reader can enter the divine-human dialogue. The first tension: texts are a dialectic, as we have seen, of fixed forms and open spaces (gaps). Second, texts are in a continual transition from surface into depth structure. ${ }^{199}$ Third, texts are always in communication with other texts, which opens up a world of meaning and orientation. ${ }^{200}$ Fourth, the semantic level of a text is in a continual transition into its pragmatic level: its dialogical dynamic, the transition from the 'said' to the 'saying'. ${ }^{201}$ This phenomenological understanding of a text opens up the space of a spiritual hermeneutic.

${ }^{197}$ K. Ruh, 'Überlieferungsgeschichte mittelalterlicher Texten als methodischer Ansatz zu einer erweiterten Konzeption von Literaturgeschichte', in: Überlieferungsgeschichtliche Prosaforschung (Ed. K. Ruh), Tübingen 1985, 262.

198 W. Iser, 'In het licht van de kritiek', in: De wetenschap van het lezen: Tien jaar theorie der literaire receptie (Ed. M. Buursink, K. Hupperetz et al.), Assen-Amsterdam 1978, 183.

199 P. Ricoeur, 'What is a text?' in: From text to action, 105-124, esp. 113-114, 121-122.

${ }^{200}$ R. Lachmann, Gedächtnis und Literatur: Intertextualität in der russischen Moderne, Frankfurt a.M. 1990.

${ }^{201}$ E. Levinas, Otherwise than being or beyond essence, Pittsburgh 1998. 
Histories. An important field of 'histories' in spirituality is the area of (auto)biographies. ${ }^{202}$ In their literary form these spiritual biographies encompass three levels of information: data documenting the spiritual model at work in the spiritual biography, both chronologically and topographically, and in terms of its chief components; ${ }^{203}$ data documenting the socio-cultural embedment; ${ }^{204}$ data providing insight in the process of divine-human transformation. ${ }^{205}$

Spiritual biographies can be seen as a paradigm of all literary witnesses of spiritual forms, schools and movements, including their various subforms and units. These 'histories' are asking for a critical analysis from different perspectives: as a spiritual model; delineating itself within a given context; mediating in the divine-human relation. ${ }^{206}$

Processes. There are three corpora of texts concerning spiritual processes, where literary studies and the study of spirituality meet one another.

The first corpus is the collection of mystical texts. Mystical texts reflect, in many cases directly, mystical experiences and processes of mystical transformation. At the same time they create for the interested reader entrances into the field of mysticism. In this process of initiation, which they mediate, they have a mystagogical function. ${ }^{207}$

The second corpus of texts reflects the practice of spiritual reading: how one detaches oneself from its self-centeredness to entrust oneself to the text; how one performs the spiritual text; how one penetrates the text and learns to savour its deeper meaning; how one's understanding has continuing impact in the practice of life. The practice of reading itself is a spiritual process: the initial attitude,

${ }^{202}$ For an overview see the article 'Biographies spirituelles', in: Dictionnaire de spiritualité, Paris 1937, vol. 1, 1624-1697.

203 Modelli di santità e modelli di comportamento (Ed. G. Barone e.a.), Torino 1984; Models of holiness (Ed. C. Duquoc \& C. Floristan), New York-Edinburgh 1979.

${ }^{204}$ P. Sheldrake, Spirituality and history: Questions of interpretation and method, London 1995, 58, 84-86, 167-168; M. de Certeau, 'Culture and spiritual experience', in: Concilium 19 (1966), 3-31; Andere structuren, andere heiligen: Het veranderende beeld van de heilige in de Middeleenwen (Ed. R. Stuip \& C. Vellekoop), Utrecht 1983.

${ }^{205}$ F. Chooi, A psychobiographical approach to interpreting hagiography: An exploratory case study of St. Francis of Assisi, Ann Arbor (MI) 1990; T. Edwards, Living in the presence: Spiritual exercises to open your life to the awareness of God, San Francisco 1994; Wyschogrod, Saints and postmodernism.

206 Sainthood revisioned: Studies in hagiography and biography (Ed. C. Binfield), Sheffield 1995.

207 See for this double-sided function of mystical texts Blommestijn \& Maas, 'Mystiek en taal', 290-301. See also J. Huls, 'Seuen manieren van minnen' van Beatrijs van Nazareth: Het mystieke proces en mystagogische implicaties, Leuven 2002; Swart, De articulatie van de mystieke omvorming in 'Die geestelike Brulocht' van Jan van Ruusbroec. 
which will be transformed by the processually structured reading process (performance, meditation, prayer, contemplation). The practice of spiritual reading provides a blueprint of a spiritual hermeneutic. ${ }^{208}$

The third corpus of texts consists in the continuous stream of commentaries on all kinds of spiritual texts. Intensive reading of a text has such a transformative influence on the reader, that she or he becomes a writer. In spiritual traditions writers are mostly readers. The texts they loved have given them the inner language to articulate their experience. From this perspective spiritual texts are essentially intertextual.

Relationships. In modern culture texts are understood as 'objects' over against a reader, whose task it is to discover the meaning of a text. Times have changed. Texts are more and more taken as a relational network, on different levels.

Firstly, texts delineate themselves against the background of other, earlier texts. Every text is the re-weaving of a slumbering texture that is again made current in a writing. ${ }^{209}$ To be a text is to be intertextual. ${ }^{210}$

Secondly, texts are intrinsically connected with readers. Some acts of the reader are indispensable, as we have seen: in the act of reading the reader, directed by the ribbon of the text, knots a network of relations within the vital back-andforth movement between the reading pasts and reading futures; he or she has to imagine a 'world'; he or she has to take his or her stand; and so forth. In one word: the reader is intimately and necessarily connected with the text. ${ }^{211}$

Thirdly, reading is transforming: 'Significance is the moment when the reader takes over the meaning, that is to say: the activation of the meaning in the existence of the reader'. ${ }^{212}$ Particularly the reading of Scripture appeals to the uniqueness of each person. Scripture yearns for the being - personally - touched of the reading subject. At this very moment, the person awakens in hearing the voice of God, which creates an immediate relation with the reader. ${ }^{213}$

Finally, texts of different traditions come together in readers, who are in search of God. The study of spirituality develops strategies for this cross-textual reading. Francis Clooney developed 'comparative' reading, which can be 'understood as an exercise in imaginative dialogue in which the hymns, prayers, and commentaries of one religious tradition are allowed to speak to similar texts from another'. ${ }^{214}$

\footnotetext{
208 Waaijman, Spirituality, 689-771.

209 Dialogizität (Ed. R. Lachmann), München 1982; Lachmann, Gedächtnis und Literatur.

${ }^{210}$ E. Jabès, Das Buch der Fragen, Frankfurt a.M. 1989.

${ }^{211}$ Iser, The act of reading.

212 P. Ricoeur, Hermeneutik und Strukturalismus, München 1973, 194.

213 Levinas, Beyond the verse, 97-98.

${ }^{214}$ M. Barnes, 'Theology of religions', in: The Blackwell companion to Christian spirituality (Ed. A. Holder), 404. See F. Clooney, Hindu God, Christian God, Oxford 2001.
} 


\section{SPIRITUALITY AND HISTORY}

Spirituality is an historical phenomenon, and as such object of historical research. Entering this field of research, one may be confronted by a lot of questions. What is the drive behind this enterprise? Is it politics, religion, or ethics: medicine for the sick mind (Livius)? Or is it curiosity and entertainment: seeking to please the ear rather than to speak the truth (Thucydides)? In whose interests is the history contracted? How to gather a trustful documentation? How to select in the enormous amount of data? How to construct an historical 'story'? How to read the 'tracks' of the past? All these questions are mutatis mutandis relevant for the history of spirituality. Is this kind of research aimed at nourishment, orientation, formation, or information? Is it to strengthen the main line and the power centre of a tradition or is it to give voice to the voiceless people (marginalized, oppressed, lay people, women etc.)? How to measure the difference between mainstream spirituality and dissidents? All these questions play at the background of the 'history of spirituality'. ${ }^{215}$

Disciplines. The Benedictine monks of the Congregation of St. Maur were the first to apply John Bodin's treatise Methodus ad facilem historiarum cognitionem (1566), and to establish the new science of history, including spirituality. At the same time the Bollandists wrote from 1643 on their Acta Sanctorum quotquot toto orbe coluntur, an impressive repository of spiritual biographies.

In the nineteenth century the source criticism of Ranke caused a complete transformation of the science of history. As in spirituality, there came a more or less clear distinction between 'history' as the events of the past itself (what happened; lived spirituality) and 'history' as the record of events (critical documentation, analysis, reconstruction; the study of spirituality).

In the beginning a strong opposition was sometimes felt against the historical approach. Legends and myths were unmasked as products of a particular lived spirituality. Gradually in the $19^{\text {th }}$ and the $20^{\text {th }}$ century, spirituality has integrated historical research.

One of the most important insights in the history of spirituality was the growing awareness that the historical context itself belongs to lived spirituality. Spirituality does not exist on some ideal plane above and beyond history, as a pure form. Spirituality is dialectically interwoven with the cultural context, in a field of tension between continuity and discontinuity. As Michel de Certeau has strikingly described: on the one hand, spirituality expresses itself in the language of

${ }^{215}$ P. Sheldrake, Spirituality and history; Id., A brief history of spirituality, Malden-Oxford 2007; see also Spiritualität und Geschichte (Ed. B. Berg), Werl 1993. 
a certain period, in which its search for the ultimate Reality takes form and content, on the other hand, that same spirituality eludes the cultural language in which it expresses itself, it cannot find the words needed, it is 'unsayable', it cannot express itself in the language of the time. ${ }^{216}$

The consciousness of the contextuality of spirituality has complicated the task of the history of spirituality. Questions about the perspective from which 'sources' are collected, registered, interpreted, reconstructed and evaluated have brought the historians beyond their own mono-perspectivesness in a 'postmodern' position of 'tracking'. ${ }^{217}$ Paradoxically, the deeper the historicity of spirituality entered in the consciousness of the historian - What is the drive beyond history?218 How different are the ways of appropriation?219 How deeply influenced is the perception of history by our own perspectives?220 - the deeper every overarching pretension looses its inner consistency. 'Indeed, attention to the complexities of history has been a major development in the study of Christian spirituality over the last thirty years'.221

Theories. Although the discipline of history in the course of the $20^{\text {th }}$ century has become more practical, concentrating itself on concrete areas of research, theoretical questions are still there. The philosophy of history, trying to read and to interpret human history, is confronted with a complex of questions.

Firstly, in days past philosophers and theologians saw it as their task to decipher the ultimate structure and meaning of history, from Augustine's De Civitate Dei to Bossuet's Histoire Universelle. Particularly in the $19^{\text {th }}$ century philosophers tried to determine the direction of evolution and history (Hegel, Marx, Buckle, Darwin, Comte, Spengler, Toynbee etc.). The question is whether this ambition is realistic.

Secondly, research of other cultures gave historians insight in the different layers of history, each with their own historical consciousness and chronological code (Eliade, Lévi-Strauss, and Vovelle).

Thirdly, after the raise of historicism from the $19^{\text {th }}$ century on, stressing the historicity of revelation and faith, some historians explored the limits of this worldview. $^{222}$

\footnotetext{
${ }^{216}$ De Certeau, 'Culture and spiritual experience'.

217 P. Nissen, 'De voorlopigheid van de waarheid', in: Speling 59 (2007) no.1, 16-20.

218 W. Frijhoff, 'Religie, geloof en kerk', in: Tijdschrift voor Nederlandse Kerkgeschiedenis 6 (2003), 3-13.

219 W. Frijhoff, 'Toeëigening: Van bezitsdrang naar betekenisgeving', in: Trajecta: Tijdschrift voor de geschiedenis van het katholieke leven in de Nederlanden 6 (1997) no.2, 99-118.

${ }^{220}$ K. Baier, 'Spiritualitätsforschung heute', in: Handbuch Spiritualität (Hrsg. K. Baier), Darmstadt 2006, 26-28.

221 Sheldrake, A brief history of spirituality, 5.

222 See for this field of questions A. Wittkau, Historismus: Zur Geschichte des Begriffs und des Problems, Göttingen 1992; F. Jaeger \& J. Rüsen, Geschichte des Historismus: Eine Einführung,
} 
Finally, historians are confronted with the tensions between the patterns of regularly recurring historical phenomena and the role of individuals modifying their environment seriously.

Professions. From a historical perspective, professions come to the fore as roles and models against the background of the socio-cultural context. 'Every society may be viewed as holding a repertoire of identities - little boy, little girl, father, mother, policeman, professor, thief, archbishop, general and so forth'.223 In spirituality, roles are changing because the historical patterns in which they function are in transition.

Historical research of spirituality reflects these processes. The majority of studies are dedicated to traditional models: the roles distributed in religious institutions, church hierarchy and other well established schools of spirituality. The lives of monks and moniales, brothers and sisters, missionaries and founders, priests and bishops are dominating in the historical scene.

Basically, after Vatican II the distribution of spiritual roles changed dramatically. The new trend became: humans find God through historically conditioned experience, relationship, and commitment, over against traditional tendencies of asceticism, removal of the world, and prayer.

Historical research has not yet developed the appropriate framework to describe 'secularized spiritualities'224 and lay-spirituality, 'constantly overlooked and unappreciated', ${ }^{225}$ and roles within forms of liberation spirituality.

In this context, a critical eye is needed to discern between different processes of socialization, interiorization, and role-taking. ${ }^{226}$ This perspective makes understandable why in some contexts roles are rejected or why there is resistance to some stigmatized roles.

Words. Every time shapes its own 'mystical repertoire'.227 In some periods, specific words play a central role. In other times, the same words have a marginalized position. New contexts create new meanings. An historical view discovers the referential, contextual, and diachronic aspects in spiritual vocabularies.

München 1992; D. Myers, Resisting history: Historicism and its contents in German-Jewish thought, Princeton-Oxford 2003; F. Ankersmit, Sublime historical experience, Stanford 2005.

223 P. Berger \& B. Berger, Sociology: A biographical approach, New York-London 1972, 62.

${ }^{224}$ The new dictionary of Catholic spirituality (Ed. M. Downey), Collegeville (MN) 1993, 478.

${ }^{225}$ E. Sellner, 'Lay spirituality', in: Ibid., 589.

${ }^{226}$ For this area see H. Sundén, Die Religion und die Rollen: Eine psychologische Untersuchung der Frömmigkeit, Berlin 1966; J. van der Lans, Religieuze ervaring en meditatie, Deventer 1980.

227 Van de Watering, Met de ogen dicht. 
One of the basic functions of language is its referential or deictic function: words point at reality, the historical reality outside language. Particular in historical critical research this referential perspective is important. All modern reference works give information about the reality words are pointing at. For instance, the Theologisches Wörterbuch zum Alten Testament and the Exegetische Wörterbuch zum Neuen Testament, and the Dictionnaire de Spiritualité cover almost all words of Christian spirituality. In these words, a spiritual world is opened up, spiritual dimensions of our being in the world.

Historical contexts create new words and load old words with new meanings. A good example is the new meaning of 'mysticism' in the $17^{\text {th }}$ century. In those days, the adjective 'mystical' turned into the noun 'mysticism' with a specific meaning: a distinct area of reality with its own language, its own logic, and its own experts: the mystics. ${ }^{228}$ The meaning of words reflects the socio-cultural context in which they are used.

Diachronically seen, the referential and contextual meanings show a history of transformations in the spiritual vocabulary. To give only one example, the word 'spirituality': in the Benedictine centuries spiritualitas referred to a total transformation in spirit; from the $11^{\text {th }}$ century on spiritualitas was contrasted with materiality; at the end of the $19^{\text {th }}$ century the word had almost completely vanished; at the start of the $20^{\text {th }}$ century 'spirituality' surfaced, designing the systematic scientific reflection on lived spirituality. 229 From the 1960s on the word became, in almost all languages and for virtually all philosophies of life, the overarching concept for everything that has to do with 'spiritual life'. 230

Things. Already in the $19^{\text {th }}$ century, scholars react upon idealistic interpretations of history. Buckle points at the influences of the material world upon history: the importance of food, soil, and the general aspect of nature upon the formation of society. Marx showed how the evolution of society is conditioned by the economic circumstances of its existence: modes of production and capital. Weber brought to the fore the relation between the raise of Protestantism and Capitalism.

It took more than a century before this perspective broke through in the history of spirituality. The liberation spiritualities in Latin America, Africa and Asia unveiled the socio-economic implications of forms of spirituality. The basic communities discovered the socio-economic dimension of spirituality. ${ }^{231}$ Women

${ }^{228}$ De Certeau, La fable mystique.

${ }^{229}$ L. Tinsley, The French expression for spirituality and devotion, New York 1953.

${ }^{230}$ J. Heagle, 'A new public piety: Reflections on spirituality', in: Church 1 (1985), 52-55.

231 P. Casaldaliga \& J. Vigil, Espiritualidad de la liberación, Santander 1992; Spirituality of the Third World (Ed. K. Abraham \& B. Mbuy-Beya), Maryknoll (NY) 1994. 
spirituality pointed at the importance of the material culture (house, clothes, food etc.) in the spirituality of every day life and the holiness of human life as it is lived. ${ }^{232}$ Ecological spirituality awoke us to the earthy character of spirituality: our bodiliness, our eating habits, the air we breathe, the presence of animals, the pollution of the environment, and so forth. ${ }^{233}$

It needs an 'archaeology' of spirituality, not limited to the research of artefacts, i.e. remains of man's past, but an 'archaeology' in the broad sense of the word: the economic dimension of spirituality, an 'archaeology' as Levinas unfolds in his Totality and Infinity, part 2 entitled Interiority and Economy, 234 encompassing body, joy, home, work, property, intimacy and so on. The 'archaeology' of this economic dimension of history of spirituality will throw a new light on primordial spiritualities, such as indigenous spirituality and secular spirituality.

Images. In spirituality, images take many shapes and perform many functions. Painting and icons, sculptures and reliefs, architecture and stained glass, music and dance - a great variety of images has been developed in the history of spirituality. Similarly, they performed a multiplicity of functions: in devotional practices or liturgy, in meditation or healing procedures, for animation or comfort, and so forth.

Impressive research has been done by historians to document and to reconstruct the successive periods of spiritual arts. Regarding Christian spirituality extensive studies of almost all periods are available. Moreover, there is the seven volume reference work Lexikon der christliche Ikonographie, ${ }^{235}$ not only offering iconographic documentation but also iconological insights. Meanwhile, critical reflections are uttered that these histories 'cannot be retrieved other than through the distorted lenses of contemporary cultural attitudes'. ${ }^{236}$

Challenging for an historical perspective are the limits of the standardized form language: spiritual arts in indigenous spirituality, the meaning of iconoclastic movements, the interpretation of nominally secular art (Friedrich, Van Gogh, Kandinsky, Mondriaan, Bacon etc.), the understanding of changing standards (the idea of the sublime in romantic nature painting).

${ }^{232}$ L. Sexson, Ordinarily sacred, Charlottesville 1992 (Orig.: New York 1982).

233 C. Cummings, Eco spirituality: Toward a reverent life, Mahwah (NJ) 1991; Essays in spirituality and ecology (Ed. J. Snelling), Leicester 1992; S. Jung, We are home: A spirituality of the environment, New York 1993; R. Taylor, The search for a sacred place: Essays toward a spirituality of nature, Ann Arbor (MI) 1992.

${ }^{234}$ Levinas, Totality and infinity, 109-183.

235 Lexikon der christliche Ikonographie (Ed. E. Kirschbaum e.a.), Rome etc. 1968-1976.

${ }^{236}$ A. Zilberstein, 'Image and spirituality', in: The new SCM Dictionary of Christian spirituality, 358-360. 
Texts. Whatever may be the self-understanding of the historian - history as the representation of facts or the hermeneutic of historical tracks, or something in between - historical research is strongly bound with texts. Of course, there are archaeological sources (seals, coins, bones, building etcetera), but without written documents the history of spirituality cannot be thought. For biblical spirituality, for instance, the historical-critical approach has unfolded a completely new dimension of the Bible. From a historical perspective texts are sources, to be interpreted and evaluated critically. This is the precise point where the history of spirituality interdisciplinarily is linked with literary sciences. It is the combination of literary and historical approaches which brought forth such great historians as Scholem, Dan, Idel, Leclercq, McGinn, Ruh and others.

Interesting is the historical approach of texts itself. As a rule text-critical editions try to reconstruct the so-called authentic text. Recent text-editorial insights however, define, as we have seen, the critical text 'historical', covering the entire history of the manuscript. ${ }^{237}$

Histories. The discipline of history is related to the histories of human life in the broadest sense. The history of spirituality is part of this phenomenon. Looking back on the great scientific historiographies in the field of spirituality of the last century, we observe a widening of the horizons.

The first great historical survey is Pourrat's La Spiritualité Chrétienne (19211930). In four volumes, the author treats the history of Catholic spirituality, starting with the Christian spirituality and at the end strongly focussing on French spirituality.

Histoire de la Spiritualité (1960-1966), similarly a work of four volumes, broadens in part II the scope, describing the spirituality of the Orthodox Church, the Protestants and the Anglicans.

Historia de la Espiritualidad (1969), again in four volumes, treats non-Christian forms of spirituality (Judaism, Islam, Gnosis, Hellenism, and so forth) and pays also attention to modern atheism.

World Spirituality (1985- ), presenting itself as An Encyclopedic History of the Religious Quest, does not limit itself to the dominant traditions (Hinduism, Buddhism, Judaism, Christianity, Islam and so on), but deals extensively with indigenous spiritualities and the secular quest (together 7 volumes). Here, the historical discipline has widened its scope to the study of religion.

These successive widenings of the horizons are reflected in unnumerous monographs on periods, currents and persons, and by detail studies in compilations and

${ }^{237}$ Ruh, 'Überlieferungsgeschichte mittelalterlicher Texte als methodischer Ansatz zu einer erweiterten Konzeption von Literaturgeschichte', 262. 
periodicals. One may say that the scientific historiography in the field of spirituality is flourishing, although studies on primordial spirituality (indigenous, lay and secular spirituality) are still in a beginning stage.

Processes. Normally, the historical research of spirituality is hesitating to go further than an accurate description of spiritual forms (lives, movements, schools, figures etc.). It scarcely dares to enter the interior horizon of these forms, their transformative power, and the way the divine-human relation takes shape in and through a concrete form, notwithstanding the fact that Hausherr already in the 1930s stressed that one should necessary interpret the spiritual dimension, incarnated in this concrete spiritual form of life - of course after the determination of the historical data. ${ }^{238}$ More than fifty years later, Edith Wyschogrod pointed out that 'saintly' life is defined as one in which compassion for the Other, irrespective of the cost to the saint, is the primary trait. ${ }^{239}$ Von der Nahmer rightly states: 'As truly as the history, and in the case of the vita, especially the personal life history of the saint, is framed in the conditions of history, still there nevertheless are at work in it - in concealed or clearly visible ways but in any case decisively - the will and power of God'. ${ }^{240}$ These two dimensions together - the contextual framework and the divine influence - constitute the 'hierophanic history' that is neither fiction nor history but that participates in both simultaneously, and is mediated by a symbolic process. ${ }^{241} \mathrm{~A}$ complete description of a spiritual form asks for an interpretation of its inner horizon, unfolding its value system, its spiritual practices, its configuration of virtues, its forms of reflection and discernment, and its mystical transformation. ${ }^{242}$ It is precisely this 'hierophanic history' which is contextual in the dynamic sense of the word: 'By "context" I mean not only a framework or external trappings, but the very element from which the experience takes its form and its expression'. ${ }^{243}$

Although the vision is present and some work has been done in this area of the interior horizon of spiritual forms, a substantial exploration of this 'hierophanic history', precisely in the dialectical tension between spirituality and culture, has to be done. ${ }^{244}$

\footnotetext{
${ }^{238}$ I. Hausherr, 'Biographies spirituelles. II. Époque byzantine', in: Dictionnaire de spiritualité, Paris 1937 , vol. $1,1634-1646$.

239 Wyschogrod, Saints and postmodernism, xxiii.

${ }^{240}$ D. von der Nahmer, Die lateinische Heiligenvita, Darmstadt 1994, 84.

${ }^{241} \mathrm{~V}$. Urubshurow, 'Hierophanic history and the symbolic process: A response to Ricoeur's call for a "Generative Poetics", in: Studies in Spirituality 7 (1997), 263-291.

${ }^{242}$ For an exploration of this inner horizon see Waaijman, Spirituality, 662-687.

${ }^{243}$ De Certeau, 'Culture and spiritual experience', 10.

${ }^{244}$ See J. Corkery, 'Spirituality and culture', in: The new SCM dictionary of Christian spirituality, 26-31.
} 
Relationships. 'There cannot be a universal definition of religion, not only because its constituent elements and relationships are historically specific, but because that definition is itself the historical product of discursive processes' ${ }^{245}$ Historical research of spirituality moves between two extremes: looking at similarities, imagining some genealogy, and looking at differences, stressing the 'otherness' and the historical concreteness.

At the one extreme, especially in the $19^{\text {th }}$ century, historical theories tried to place the different spiritualities within a historical frame of world history (in fact a Western frame). But also in the $20^{\text {th }}$ century scholars tried to think the togetherness of spiritualities. Franz Rosenzweig argues that Judaism is intrinsically related with Christianity, both going the way to the Kingdom of God. ${ }^{246}$ Panikkar sees the different spiritualities as the unfolding of a triadic pattern, mirroring the triune life within the (Christian) Godhead. ${ }^{247}$

At the other extreme, especially in postmodern theories, scholars stress the concrete historicity of spirituality. Spirituality does not exist 'apart from concrete historical life'. ${ }^{248}$ Although it is possible 'to posit some sort of common foundation or essence for the religions, to seek out and build on the "family resemblances" between religious traditions', on closer examination one will discover, 'that the world religions are not discrete versions of some transhistorical essence but complex historical constructions'. ${ }^{249}$

Without harmonizing the extremes, one may agree with Cousins, unfolding his 'encyclopedic history of the religious quest' as a spiritual journey, a meeting place for spiritualities, 'that the meeting of spiritual paths - the assimilation not only of one's own spiritual heritage but of that of the human community as a whole - is the distinctive spiritual journey of our time. ${ }^{250}$

\section{SPIRITUALITY AND ANTHROPOLOGY}

The anthropological approach is the most recent development in the field (of academic spirituality, kw) and most clearly influenced by Postmodernity, both cultural and academic. This approach is rooted in the recognition that spirituality is

245 Talal Asad, Genealogies of religions, Baltimore (MD) 1993, cited by Barnes, in: 'Theology of religions', 409.

246 F. Rosenzweig, Star of redemption, London 1970.

${ }^{247}$ R. Panikkar, The Trinity and the religious experience of man, Maryland (NY) 1973.

${ }^{248}$ M. McIntosh, Mystical theology, Oxford 1998, 5.

${ }^{249}$ Barnes, 'Theology of religions', 408. See also R. Williams, On Christian theology, Oxford 2000.

${ }^{250}$ E. Cousins, 'Preface', in: Christian spirituality: Origins to the twelfth century, London 1986 (World Spirituality 16), xv; see also Id., Christ of the 21 th century, Rockport 1992. 
an anthropological constant, a constitutive dimension of the humanum' .251 Characteristic for an anthropological spirituality is the emphasis on hermeneutical methodology, reading lived spirituality basically as a human search for (self)transcendence and meaning. ${ }^{252}$ This methodology has, indeed, as every classical anthropological field-work, a 'double focus: understanding and explanation (i.e., the expansion of knowledge), on the one hand, and appropriation (i.e., the expansion of subjectivity), on the other'. ${ }^{253}$ This hermeneutical methodology is part of the phenomenological approach, from the beginning of the $20^{\text {th }}$ century.

Apart from methodology, anthropology conceives spirituality as a universal human quest, significant for the human enterprise as a whole.

Disciplines. Anthropology is a multilayered discipline. Firstly, it was used in the philosophical faculties of the German universities at the end of the $16^{\text {th }}$ century. It attempted to regroup the specialized disciplines within a common purpose: the humanity of man. In the $18^{\text {th }}$ century the discipline splitted into physical anthropology (investigating the place of man in nature, comparing himself with other primates and interpreting the race differences) and cultural anthropology (considering man as a social being individualized by historical and geographical factors). Spiritual anthropology emerged within cultural anthropology. Long times studies on spirituality were ignored. Edith Turner describes, 'how the discipline of anthropology had to break open to include spirituality'. ${ }^{254}$ From the 1980s anthropologists like Bruner, Fernandez, Grindal, and Tedlock paved the way for an anthropology of experience and consciousness. ${ }^{255}$ During last decades, an increase is visible in the number of notable publications on spirituality, healing, shamanism, radical empathy, radical participation, and the work of anthropological practioners. ${ }^{256}$ In the same time research groups and schools of thought focussed on spiritual anthropology. 257

\footnotetext{
251 S. Schneiders, 'The study of Christian spirituality', in: The Blackwell companion to Christian spirituality, 26; with a reference to J. Breton, Approche contemporaine de la vie spirituelle, Montreal 1990 .

252 Ibidem.

253 Ibidem, referring to P. Ricoeur, Interpretation theory: Discourse and the surplus of meaning, Fort Worth 1976, 71-95.

${ }^{254}$ E. Turner, 'Advances in the study of spirit experience: Drawing together many threads', in: Anthropology of Consciousness 17 (2006) no.2, 41.

255 The anthropology of experience (Eds. E. Bruner \& V. Turner), Urbana 1986; B. Grindal, 'In the heart of Sisala experience: Witnessing death divination', in: Journal of Anthropological Research 39 (1983) no.1, 60-80; D. Tedlock, Days from a dream almanac, Urbana 1990.

256 Turner, 'Advances in the study of spirit experience', 45-51.

257 Ibid., 52-55.
} 
The consequence of this spiritual turn in anthropology was an epistemological shift. In order to perceive and to understand the level of spirituality in a culture, one needs a participatory attitude: 'Anthropological writers should allow the events of the field - be they extraordinary or mundane - to penetrate them'. ${ }^{258}$ Spiritual experience can not be registered objectively. On this level information is transformation. It needs a 'method' which is empathic and participative: 'What is needed for this kind of fieldwork is a technique of participation that demands total involvement of our whole being. Indeed it is perhaps only when we truly and fully participate in this way that we find this essentially subjective approach to be in no way incompatible with the more conventional rational, objective, scientific approach. On the contrary, they complement each other and that complementarity is an absolute requirement if we come to any full understanding of the social process'. ${ }^{259}$

Theories. The Age of Discovery confronted the modern West with cultures that remained outside its horizon. They were experienced as foreign and therefore labelled as 'savage', 'primitive', 'preliterate', and so on. Cultural anthropology can be seen as a scientific answer on this experience of 'otherness'. During the time, this answer itself was transformed by the challenges of its 'object'.

Firstly, anthropology could not remain insensitive for its own presuppositions. Particularly the philosophical anthropology was confronted with different images of man: image of God, natural being, product of evolution, product of culture, mystery, individual, Thou, etc. These reflections were deeply influenced by developments in the Western culture itself. Theological anthropology is dealing with these 'spiritual' questions. ${ }^{260}$ Theology itself seems to become anthropology, looking for 'anthropological constants' as a basic system for theological reflections. ${ }^{261}$ In fact, anthropology and theology seem to be interrelated precisely on the level of spirituality, that is to say, on the level of the divine-human relationship. This seems particularly relevant at the limits of both realities:

There is a striking correlation between the themes of the death of God and the death of man; this correlation seems to verify the mutual interrelation of theology and anthropology. (...) For most philosophical anthropologists, the theological dimension, or some reference to God, is indispensable in order to hold in

258 P. Stoller, 'Mind, eye, and word in anthropology', in: L'Homme 24 (1984) nos 3-4, 91-114.

${ }^{259}$ C. Turnbull, 'Liminality: A synthesis of subjective and objective experience', in: By means of performance (Ed. R. Schechner \& W. Appel), Cambridge 1990, 51.

260 J. Ruffing, 'Theological anthropology', in: The new dictionary of Catholic spirituality, 47-50; L'Antropologia dei maestri spirituali (Ed. C. Bernard), Milano 1991. See also Explorations in anthropology and theology (Ed. F. Salmona \& W. Adams), Lanham-New York-Oxford 1997.

${ }^{261}$ E. Schillebeeckx, Christ: The experience of Jesus as Lord, New York 1981, 734-743. 
check the contradictory threats that would destroy the image of man and to maintain the opening to transcendence in which each individual consciousness can discover its meaning, its values, and its freedom. ${ }^{262}$

Secondly, the basic idea of culture itself was shocked by anthropological research. The common scientific approach of anthropologists as Mauss, Métraux, LéviStrauss, Malinowski, Radcliff-Brown and others was system oriented: the only way to explain facts was to define the function they perform in a given culture. Spiritual anthropology opposed strongly against the presupposed idea that all power inevitably must be attributed to society and culture, especially as regards religion. The idea of anti-structure made it possible to understand liminal processes, including mystical transformations. ${ }^{263}$

Lastly, the otherness of foreign cultures challenges Western researchers to evaluate their methodology. As long as other cultures, within a colonizing attitude can be 'objectified', the scholars are more or less 'safe'. But from the moment on, that they loose their monopoly of objectivity and empathy, encounter and participation become part of their research strategy, the perspective of the 'other' becomes more and more influential. This causes 'a change in ethnographic epistemology'.264

Professions. Practices and professions in the field of spiritual anthropology are complicated. Seen from the perspective of the anthropologists themselves, we may observe a very broad spectrum. At the one end, there are the anthropologists who sit behind their desks and read. In between we encounter field workers with an objectifying approach. At the other end, the field workers, particularly in the field of spiritual anthropology, 'experience as practioners, actual practioners, the healings their friends were engaged in'. ${ }^{265}$ But even than, being part of the spiritual culture, in which they 'went native', they are practioners of the Western culture as witnesses of mostly small cultures, threatened by Western dominance. They are 'marginals' in the sense of Victor Turner: belonging to two worlds, living in-between.

\footnotetext{
262 G.P. Gusdorf, 'Philosophical anthropology', in: The new Encyclopaedia Britannica, Chicago etc. 1980, vol. 1, 975-985: 985.

${ }^{263}$ V. Turner, The ritual process: Structure and anti-structure, London 1962.

${ }^{264} \mathrm{~B}$. Tedlock, 'From participant observation to the observation of participation: The emergence of narrative ethnography', in: Journal of Anthropological Research 47 (1991) no.1, 69-94. See also S. Kimball, 'Learning a new culture', in: Crossing cultural boundaries: The anthropological experience (Ed. S. Kimball \& J. Watson), San Francisco 1972; E. Turner, 'Fear of religious emotion versus the need for research that encompasses the fullest experience', in: Selected readings in the anthropology of religion: Theoretical and methodological essays (Eds. S. Glazier \& C. Flowerday), Westport (CT) 2003, 109-118.

265 Turner, 'Advances in the study of spirit experience', 44.
} 
Seen from the perspective of native spirituality itself, anthropology is mainly focussed on two practices and professions. Firstly, many studies appeared in the field of shamanism. ${ }^{266}$

A step forward in this field of research is The Encyclopedia of Shamanism, signaling the recognition of shamanism in the academia. ${ }^{267}$ Important can become the new shamanic studies institute in Moscow (2005), named Merzakerin Norbekov Institute. Secondly, there is the study of the healing practices in indigenous spiritualities. ${ }^{268}$

Words. On a purely practical level anthropologists need knowledge of the language of the people they are studying. Often they have to make the first survey of it and to compose the first lists of words. These efforts mostly were embedded in the strategy of missionary activities or cultural expansion. In the anthropology of experience, the methodological insight emerged. The point of departure should be the expressions used by people belonging to a culture: 'The advantage of beginning the study of culture through expressions is that the basic units of analysis are established by the people we study rather than by the anthropologists as alien observer. (...) Expressions are the people's articulations, formulations, and representations of their own experience'. 269

Things. Things play an important role in shamanic performances and healing rituals. In this respect the meaning of things has been studied in the anthropology of experience. But within the framework of spirituality the material culture has

266 To mention only K. McCarthy Brown, Mama Lola: A Vodou priestess in Brooklyn, Berkeley 1991; C. Laderman, Taming the wind of desire: Psychology, medicine, and aesthetics in Malay shamanistic performance, Berkeley 1991. A classic is of course M. Eliade, Shamanism: Archaic techniques of ecstacy, Princeton (NJ) 1972. See also E. Turner, 'From Shamans to healers: The survival of an Iñupiat Eskimo skill', in: Anthropologica 31 (1989), 3-24; Tedlock, Days from a dream almanac; Idem, The woman in the Shaman's body: Reclaiming the feminine in religion and healing, New York 2005.

267 The encyclopedia of Shamanism (Ed. M. Walter \& E. Fridman), Santa Barbara (CA) 2005.

${ }^{268} \mathrm{~J}$. Neihardt, Black Elk speaks: Being the life story of a holy man of the Oglala Sioux, Lincoln-London 1961; L. Peters, Ecstasy and healing in Nepal: An ethno-psychiatric study of Tamang shamanism, Malibu (CA) 1981; R. Desjarlais, Body and emotion: The aesthetics of illness and healing in the Nepal Himalayas, Philadelphia 1992; E. Turner, Experiencing ritual: A new interpretation of African healing, Philadelphia 1992; Id., The hands feel it: Healing and spirit presence among Northern Alaskan people, DeKalb (IL) 1996; Gary Holy Bull, Lakota Yuwipi man: Healing rituals and teachings of the Sioux medicine man (B. Keeney), Chicago 2000; Religion and healing in America (Ed. L. Barnes \& S. Sered), New York 2005; E. Turner, Among the healers: Spiritual and ritual healing across the world, New York 2005; Spiritual transformation and healing (Ed. J. Koss-Chionino \& P. Hefner), Lanham (MD) 2006.

${ }^{269}$ E. Bruner, 'Experience and its expressions', in: The anthropology of experience, 9. 
not been reflected. This one-sidedness is caused by theoretical presuppositions. Spiritual anthropology is particularly focused on 'spirits', the 'reality' of these spirits, and the ways to come in 'contact' with this spiritual realm. By doing so the attention for the spiritual meaning of the material culture has been pushed to the background.

Images. In the $20^{\text {th }}$ century, anthropologists became interested in the way in which myth, ritual, and symbolization operate within the various religious traditions. Art, images, and symbols are not objective things, but spiritual programs of performance and transformation. ${ }^{270}$

Another important contribution of cultural anthropology to the study of spirituality is the perception of art, symbolism, and rituals as essential parts of the whole of a culture, i.e. the whole of a spiritual architecture. In spirituality 'art' (pictures, dance, music, architecture etc.) ${ }^{271}$ cannot be separated from the sociocultural whole in which it functions. In a concentrated 'performance', it unfolds a transformative power and realizes an intense contact between deep emotions and central values. ${ }^{272}$ Cultural anthropology has provided for the dimension of art, images and symbols a framework of interpretation. ${ }^{273}$

Texts. To get access to the inner horizon of a culture anthropologists need not only descriptions of behaviour and rituals, they also need the 'eye' of experience, expressed in myths, folk tales, proverbs, and so on. Therefore, one of the first tasks which the anthropologists imposed themselves was to collect the various forms of oral expression. Toward the end of the $19^{\text {th }}$ century tales were collected in such an encyclopedic work as Grawley's Mystic Rose (1902), collections of religious and spiritual practices.

The main contribution of anthropology in the last decades is the description of so called indigenous spiritualities all over the world, from the Aborigines in Australia to the Native Spiritualities in North-America, from the islands of New Zealand to the Afro-Brasilian cultures. These descriptions contain a lot of spiritual texts: prayers, mystagogical instructions, visions, and so on. ${ }^{274}$ But till now,

\footnotetext{
270 See S. White, 'Ritual studies', in: The Blackwell companion to Christian spirituality, 387-400.

271 S. Friedson, Dancing prophets: Musical experiences in Tumbuka healing, Chicago 1996.

272 P. Brook, The empty space, Harmondsworth 1982; C. Geertz, Interpretation of cultures, New York 1977; R. Grimes, Reading, writing, and ritualizing, Washington 1993.

${ }^{273}$ Faithful performances (Eds. T. Hart \& S. Guthrie), Abingdon 2007; F. Kline, 'Artistic performance and ascetic practice', in: Spiritus 2 (2002), 173-179.

274 To give an impression: A. Borsboom, De clan van de Wilde Honing: Spirituele rijkdom van de Aborigines, Haarlem 2006; L. Hume, Ancestral power: The dreaming, consciousness, and Aboriginal Australians, Carlton South 2002; M. Charlesworth, Religious business: Essays on Australian Aboriginal spirituality, Cambridge 1998; L. Irwin, Native American spirituality: A critical reader,
} 
no systematic reflections are dedicated to hermeneutical questions like: what does happen with 'texts', when they are transposed from their oral to their written form; how to construct by audio-visual means a scientific registration; how to interpret these 'texts' from the viewpoint of spirituality, and so on?

Histories. Originally, anthropology was based on an evolutionist approach. For a lack of written documents, no historical record could be determined. Therefore these cultures where called 'prehistoric'. As we have seen in the last century, a broad stream of texts and descriptions are produced, bringing these cultures within the horizon of 'history'. Almost every indigenous spirituality has been described.

The above mentioned reference work World Spirituality is groundbreaking, with considerable space assigned to indigenous spiritualities 5 of the planned 25 volumes): Asian Archaic Spirituality, European Archaic Spirituality, African Spirituality, South and Meso-American Native Spirituality, and North American Indian Spirituality. ${ }^{275}$ These studies describe a basic form of spirituality which, in its primordiality, has to be distinguished from the schools of spirituality, being part of an overarching world religion. ${ }^{276}$ In a parallel process Europe also rediscovered the primordial spiritualities. ${ }^{277}$

Processes. The anthropology of experience ${ }^{278}$ can be seen as a 'rebellion against structural-functional orthodoxy, with its closed static model of social systems' ${ }^{279}$ Using Van Gennep's The Rites of Passage $e^{280}$ Victor Turner expanded the notion of liminality (being the transitional middle stage in the rite of passage, between separation and re-integration), identifying many of those liminal moments that did not belong to the social structure. He recognized this liminality in the rites

Lincoln etc. 2000; E. Tooker, Native North spirituality at the Eastern Woodland: Sacred myths, dreams, visions, speeches, healing formulas, and ceremonials, New York etc. 1979; A. Doumbiq, The way of elders: West African spirituality \& tradition, St. Paul (MN) 2004; M. Milder, Dansen om te leven: Over Afro-Braziliaanse cultuur en spiritualiteit, Heeswijk 1999; B. Glass-Coffin, The gift of life: Female spirituality and healing in Northern Peru, Albuquerque 1998; R. Ellwood, Islands of the dawn: The story of alternative spirituality in New Zealand, Honolulu 1993.

275 Meanwhile African Spirituality and South and Meso-American Native Spirituality are published.

276 Waaijman, Spirituality, 18-27.

${ }^{277}$ For instance, the Celtic spirituality: P. Thomas, The opened door: A Celtic spirituality, Brechfa 1990; E. de Waal, Celtic light: A tradition rediscovered, London 1997; P. O’Dwyer, Toward a history of Irish spirituality, Blackrock-Dublin 1995; P. Sheldrake, Living between worlds: Place and journey in Celtic spirituality, London 1995; R. Simpson, Exploring Celtic spirituality: Historical roots for our future, London 1995.

278 See The anthropology of experience.

${ }^{279}$ B. Babcock, 'Victor W. Turner: Obituary', in: Journal of American Folklore 97 (1984), 462.

${ }^{280}$ A. van Gennep, The rites of passage, Chicago 1960. 
of passage of African tribes, but also in a variety of betwixt-and-between circumstances in other societies. ${ }^{281} \mathrm{His}$ analysis has been very influential in spirituality, to understand spiritual growth in the area of 'anti-structure' (fruitful chaos, a place of incubation for new ideas and lifestyles, of resistance and creativity, of communitas), a 'nowhere' outside of 'structure'. ${ }^{282}$

Rituals of initiation and healing give knowledge of deep connection (communitas) and a change in consciousness. To give one example, Colin Turnbull tells how he, being with the forest people of the Ituri in Congo during the 1950s, experienced the highest sense of mystical unity, which came to him at the sound of the pygmies singing, at night seated around a fire, to cure someone's sickness. He was transformed into another mode of perception, going beyond ordinary consciousness. ${ }^{283}$

Relationships. One of the most challenging developments in the study of spirituality is the documentation of indigenous spiritualities. These forms of primordial spirituality, handed over in oral traditions, are mostly preserved and interpreted by anthropologists. A characteristic of this form of spirituality is its feeling for connectedness. We may observe this in Sub-Saharan spirituality. ${ }^{284}$ The actual setting of this spirituality is the family. A person lives in fellowship with the other members of the community as brothers and sisters. Hospitality and social justice are integral to this community. ${ }^{285}$ Being born into a family, one participates in the current of generations. Within this genealogical system the ancestors play an important role. The living generation receives from them their life-giving influence. ${ }^{286}$ The human community participates in the natural environment being a divine reality: 'The moon and the stars, the rivers and the seas, the hills and the mountains, fish and animals and human beings - all carry the message of God's presence'. ${ }^{287}$ The divine power is immediately experienced in the universe: 'God is the beginning without end. All that exists has its origin and meaning in God and will terminate in God'. ${ }^{288}$ African spirituality is

\footnotetext{
${ }^{281}$ V. Turner, The ritual process; Id., Dramas, fields and metaphors: Symbolic action in human society, Ithaca 1974.

${ }^{282}$ For a description of this field of spiritual counter-movements see Waaijman, Spirituality, 212303.

${ }^{283}$ Turnbull, 'Liminality', 58.

${ }^{284}$ For this widespread form of African spirituality, see G. Huizer, Folk spirituality and liberation in Southern Africa, Talence (France) 1991; P. Paris, The spirituality of African peoples, Minneapolis 1995.

285 B. Lele, Family spirituality in Africa, Eldoret (Kenya) 1982.

286 A. Ehirim-Donko, African spirituality: On becoming ancestors, Trenton (NJ) 1997.

287 C. Egbulem, 'African spirituality', in: The new dictionary of Catholic spirituality, 19.

288 Ibid., 18.
} 
a paradigm of indigenous spirituality, showing that 'relationality' is an essential element in this form of spirituality: genealogy, extended family, environment and the divine presence are one all-permeating reality. ${ }^{289}$

\section{SPIRITUALITY AND PsyChOlOGY}

'Because the intrinsic inter-relationships between spirituality and psychology both fields concentrating on human interiority and its patterns of deformation, development, integration, and its relationship to the sacred - this particular dialogue has moved from hostility to rivalry, to mutual cooperation, and to mutual respect'. ${ }^{290}$ In many schools of psychology, cooperation and respect have become intense interest, and sometimes overwhelming love. 'The current interest from the perspective of psychology is so intense that psychology may well become the authoritative discipline in the study of spirituality on the basis of the sheer quantity of studies and practioners who are rapidly incorporating spirituality in their research and therapeutic work' ${ }^{291}$ The question, however, is whether this intense interest is not a Procrustes bed. The 'shortened' definition - something like: spirituality is that which gives meaning to life and allows us to participate in the larger whole - may cut off spirituality from 'the half of its body'? Despite this critical question - there are more questions - the explosion of research in the last decade and a half provides a fundament for intensifying the interdisciplinarity between psychology and spirituality. ${ }^{292}$

Disciplines. Rightly, Ruffing stated that the interaction between spirituality and psychology started with 'hostility'. Up until the beginning of the $20^{\text {th }}$ century the interdisciplinarity between spirituality and psychology was blocked on both sides. Spiritual theology had locked up itself in scholastic theology: spirituality and mysticism can only be properly studied from the perspective of dogmat-

${ }^{289}$ For other indigenous spiritualities see E. MacGaa, Mother Earth spirituality: Native American paths to healing ourselves and our world, San Francisco 1990; M. Charlesworth, Ancestor spirits: Aspects of Australian Aboriginal life and spirituality, Melbourne 1990; A. Gray, The Arakmbut: Mythology, spirituality, and history in an Amazonian community, ProvidenceOxford, 1996.

${ }^{290}$ J. Ruffing, 'Personality sciences', in: The Blackwell companion to Christian spirituality, 308.

${ }^{291}$ Ibidem.

${ }^{292}$ For recent overviews see J. van der Lans, 'Psychologie van de mystiek', in: Encyclopedie van de mystiek, 257-284; J. Shea, 'Spirituality, psychology and psychotherapy', in: The new SCM dictionary of Christian spirituality, 49-54; Ruffing, 'Personality sciences', 308-324.

${ }^{293}$ E. Krebs, Grundfragen der kirchlichen Mystik dogmatisch erörtert und für das Leben gewertet, Freiburg i.Br. 1921; A. Stolz, Theologie der Mystik, Regensburg 1936. 
ics. ${ }^{293}$ In the same period psychology assumed a one-sided medical-positivistic attitude. Psychologists concentrated on extra-ordinary symptoms and explained them as pathological processes. Teresa of Avila was considered as a hysteric; ${ }^{294}$ Paul the apostle and Dostoyevsky were diagnosed as epileptics. ${ }^{295}$ Nor did the non-medical-biological psychology of Freud and his successors offer more solace. In line with the abstract-negative attitude toward religiosity, few openings were offered for interdisciplinary dialogue.

Gradually, the two disciplines began to open up to each other. In spiritual theology scholars discovered the experiential side of mysticism. ${ }^{296}$ Heerinckx even spoke about the 'two sources' of spirituality: theological sources and experiential sources. ${ }^{297}$ Among the latter, he mentions experimental psychology, the psychology of religion, the experience present in the lives of saints and the spiritual biographies, and personal experiences, especially from the practice of spiritual accompaniment. The ice was broken. In the 1930s Père Bruno organized his annual international congresses on the psychology of religion in Avon, culminating in the famous series Etudes Carmélitaines. ${ }^{298}$ From the perspective of psychology, an impressive breakthrough came with William James' The Varieties of Religious Experience. ${ }^{299}$ As a phenomenologist, James documented, analysed and described mysticism as a phenomenon in its own rights, discovering basic themes like: conversion, awareness of Presence, mysticism etc. With this, the climate of classic study changed. From different perspectives, psychologists started to study the phenomenon of spirituality.

In the last decades, we are interdisciplinary in the stage of 'mutual cooperation' and 'mutual respect', as Ruffing stated. Numerous studies appeared. Surveying the literature, we discern a number of interdisciplinary lines. Some look at spiritual processes from the standpoint of a particular psychological scheme. Others immerse themselves in spiritual traditions with an eye to their psychological implications. Still others reserve for spirituality a scientific field of its own alongside psychology. ${ }^{300}$ It was entirely in line with this interdisciplinary cooperation that the American Psychological Association in 1988 added 'spirituality' to

\footnotetext{
${ }^{294}$ G. Hahn, Die Probleme der Hysterie und die Offenbarungen der Heiligen Therese, Leipzig 1906, 114. 295 See for this medical psychiatric view J. Leuba, The psychology of religious mysticism, LondonBoston 1925.

${ }^{296}$ A. Poulain, Des grâces d'oraison: Traité de théologie mystique, Paris 1901; M. Grabmann, Wesen und Grundlagen der Katholischen Mystik, München 1923; A. Mager, Mystik als seelische Wirklichkeit: Eine Psychologie der Mystik, Graz-Salzberg 1946.

${ }^{297}$ J. Heerinckx, 'De theologiae spiritualis studio', in: Antonianum 4 (1929), 209-230; 303-336; 431-454.

${ }^{298}$ L. Beinaert, Expérience chrétienne et psychologie, Paris 1964, 41.

299 W. James, The varieties of religious experience, Edinburgh 1901/1902.

${ }^{300}$ For an overview see Waaijman, Spirituality, 416-418.
} 
the official index of key terms. ${ }^{301}$ At the same time, however, the question comes up whether spirituality is not 'shortened' on the bed of Procrustes. The most important field of tension is the tension between intrapsychic versus dialogical interpretations. ${ }^{302}$

Theories. Prior to the $19^{\text {th }}$ century, the content and the methodology of psychology were predominantly philosophical, oriented on questions about the essence of the human mind, the relation between mind and body, knowledge and world, experience and reality. The rise of psychology as an independent experimental science with the establishing of laboratories was at the same time a break with the classical philosophy of psychology.

New theoretical frameworks filled up the vacuum created by this process of emancipation. A variety of schools, each of them in full development, entered the interdisciplinary space between psychology and spirituality. To mention only the most influential schools, Freudian psychoanalytic theory sees religiosity as a defensive distortion of individual's libido, creating the illusion of our 'childish helplessness'. Behaviourists believe that human behaviour is determined by external environment. Rogerians presuppose that if we were accepted unconditionally, we would be in 'congruence', which can be furthered by empathy and unconditional positive regard. Jungians understand human life as a process of individuation, becoming a whole person, a self, via the transformation of the conscious by the unconscious. Frankl sees the essence of the human being as the orientation on the ultimate meaning, realized in freedom, responsibility and the will-to-meaning. Erikson sees human life as the unfolding of the basic trust, according a developmental schema, which extends through the life-cycle with characteristic tasks and virtues for each stage. Transpersonalists aim at the integration of disintegrative factors around a presupposed transpersonal centre and the development of the consciousness in its divine unfolding. ${ }^{303}$

Vis-à-vis such a variety of theoretical prepositions and perspectives we are invited to reflect on its meaning from the viewpoint of spirituality, understood as

\footnotetext{
301 American Psychological Association, Thesaurus of psychological index terms, Arlington 1988.

${ }^{302}$ H. Blommestijn, 'Psicologia della mìstica', in: La spiritualità come teologia (Ed. C. Bernard), Milano 1993, 232-251; Id., 'Découverte de soi-même ou quête du Dieu: L'itinéraire de soi en Dieu chez Maître Eckhart', in: Studies in Spirituality 1 (1991), 25-35.

303 To give an impression of the interdisciplinary variety: M. Eigen, The psychoanalytic mystic, Binghamton 1998; F. Halligan \& J. Shea, The fires of desire: Erotic energies and the spiritual quest, New York 1992; M. Washburn, Transpersonal psychology in psychoanalytic perspective, Albany (NY) 1994; L. Jaffe, Liberating the heart: Spirituality and Jungian psychology, Toronto 1990; A. Ulanov, Carl Jung and Christian spirituality, New York 1988; E. Liebert, Changing life patterns: Adult development in spiritual direction, Mahwah (NJ) 1992; B. Cortright, Psychotherapy and spirit: Theory and praxis in transpersonal psychotherapy, Albany (NY) 1997.
} 
divine-human relationship. We are placed in a field of tensions, asking for fundamental reflection: intrapsychic-interpersonal; growth-being; acting-awareness, conscious-unconscious; dependent-independent-interdependent; internal-external; self esteem-unconditional acceptance; self-Self; self-other; freedom-responsibility; human-divine; and so forth. Whatever the result of these fundamental reflections may be, all the differences and tensions belong to the realm of spirituality.

Professions. Within the interdisciplinary field of spirituality and psychology, two roles come to the fore: psychotherapists and spiritual accompanists.

Regarding the psychotherapists, John Shea distinguishes three categories. ${ }^{304}$ The first category finds spirituality incompatible with psychology, and therefore has little or no interest in spirituality, making clear dichotomies (secular-sacred; human-divine, science-spirituality, etc.). The second category is interested in finding ways to integrate spirituality in their practice of psychotherapy, mostly having a holistic understanding of the person and willing to make the resources of spirituality (hope, trust, serenity, responsibility etc.) available to their clients. ${ }^{305}$ The third category understands the human person as inherently spiritual and for them, spirituality is the very definition of their profession. One or more of the above mentioned psychologies (Freud, Jung, Frankl, Erikson, Rogers, Assajoli, etc.) are a factor in the practice of psychotherapy.

Regarding the spiritual accompanists, if we understand spiritual direction as a dynamic triangle (the divine reality, the person being accompanied, the accompanist), the interdisciplinarity spirituality-psychology is essential on two points. Firstly, the accompanist has to enlarge her or his inner listening space and empathy, by training in self-knowledge and social skill. Secondly, the one being accompanied is invited to become more familiar with her or his intrapsychic world. Spiritual accompaniment cannot abstract itself from the psychic constellation. ${ }^{306}$

Words. The root metaphor of psychology is psuchè, which means 'soul'. This word belongs to the semantic field of mind, spirit, consciousness, centre, source of knowledge, feeling, and so forth.

From the viewpoint of psychology, an interest in the semantic field around spiritual key words is not evident, till now. On the contrary, leaving the theoretical framework of philosophy and orienting itself on empirical methodologies, the focus became more and more behaviouristic and even behaviour lost its identity.

\footnotetext{
304 Shea, 'Spirituality, psychology and psychotherapy', 52-54.

305 Integrating spirituality into treatment: Resources for practioners (Ed. W. Miller), Washington DC 1999; J. Swinton, Spirituality and mental health care: Rediscovering a 'forgotten' dimension, London 2001.

306 See for this field of spiritual accompaniment Waaijman, Spirituality, 882-894.
} 
As a short ironic history of psychology tells us: 'Pity poor psychology. First it lost its soul, than its mind, then its consciousness, and now it's having trouble with behaviour'. 307

From the viewpoint of spirituality, there is no real interest in the psychological vocabulary of spiritual words. Even in the newest dictionaries we observe only the traditional sources: bible, patristics, middle ages, and modern times. That is all.

Things. From the $19^{\text {th }}$ century on, psychology assumed a medical-positivistic attitude, looking for deeper insight in the material basis of spiritual experiences and processes. Particularly psychiatry was focussed on the medical aspect of spirituality and mysticism, noting extraordinary symptoms, classifying them in accordance with medical syndromes (depression, anxiety, phobias, obsession, schizophrenia, delusions, hallucinations and other forms of pathology) and emphasizing genetic predispositions, anatomical, physiological and biochemical processes. Leuba, for example, considered mysticism as a form of erotomanism, and the mystical experience as a compensation of a paranoid sexual frustration - in fact a variation on Freud's (hypo)thesis that mysticism is a primary narcissistic regression..$^{308}$

In recent times, some research groups are focused on the physical causes and/or preconditions of mystical experiences: brain, nervous system, and endocrine system. ${ }^{309}$ Persinger developed the theory that spiritual experiences, very similar to epileptic experiences, are caused by neuro-electric patterns, located in the temporal lobe of the left hemisphere of the brain. ${ }^{310}$ In the same direction, Ramachandran and his colleagues are doing research in the Center for Brain and Cognition. ${ }^{311}$ Other neuropsychologists are focused on spiritual phenomena as meditation, prayer, and conversion. ${ }^{312}$ One of the side effects of the

307 Cited in the article on psychology in: Encyclopaedia Britannica 1961, vol. 18, 682.

308 See Leuba, The psychology of religious mysticism; G. Coe, The spiritual life: Studies in the science of religion, New York 1900; E. Starbuck, The psychology of religion, London 1899/1901; S. Freud, 'Das Unbehagen in der Kultur' (1930), in: Gesammelte Werke. Band XIV, Frankfurt a.M 1944, 421-506.

${ }^{309}$ For an overview see P. Widmer, Mystikforschung zwischen Materialismus und Metaphysik: Eine Einfuhrung, Freiburg i.Br. 2004; Idem, 'Die angelsächische Mystikdebatte: Eine Einführung', in: Handbuch Spiritualität, 49-71.

310 M. Persinger, Neuro-psychological bases of God beliefs, New York 1987; Id., 'Vectorial cerebral hemisphericity as differential sources for the sensed presence, mystical experiences and religious conversions', in: Perceptual and Motor Skills 76 (1993), 915-930; Id., 'Religious and mystical experience as artefacts of temporal lobe function: A general hypothesis', in: Perceptual and Motor Skills 57 (1983), 1255-1262.

311 V. Ramanchandran \& S. Blakeslee, Phantoms in brain, London 1998.

312 E. d'Aquili \& A. Newberg, The mystical mind: Probing the biology of religious experience, Minneapolis 1999; A. Newberg, E. d'Aquili \& V. Rause, Why God won't go away: Brain science and 
neurophysiologic approach has been the so called mystical experiences caused by drugs and chemical means, the effects of it being loss of consciousness of reality and change of time and space. ${ }^{313}$

The main question is whether the neurophysiologic data monocausally explain spiritual phenomena or describe aspects of the human preconditions, given the fact that these data show a pluriformity in expression influenced at least by socialisation and gender. ${ }^{314}$ Moreover, questions are posed about the criteriology, particularly concerning instant experiences and ongoing processes of transformation. ${ }^{315}$ Finally, sometimes explanation and validation are mixed up. ${ }^{316}$ But the basic question remains whether the neurological pattern is a physical cause which brings about the illusion of the divine reality or an organ, which is to be transformed by the divine-human encounter.

Images. Art belongs to the broader field of creativity. This creativity, as an experimental process, can be the point where spiritual processes in art can become psychologically understandable.

First of all, creativity is an experimental process. From the viewpoint of the art-consumer: when people have been touched by a picture, a symbol, a poem or a melody, they are so deeply moved that they view themselves differently than they do in the case of every day conditions. It sets fundamental layers of the viewer's psyche in motion. ${ }^{317}$

Secondly, artists and participants are in search of true reality. They leave the exterior behind them and focus all their attention on the elementary simplicity of reality itself. Entering the interior reality, one is born into a new world and achieves new life. ${ }^{318}$

Thirdly, artists and consumers are getting involved with a reality disclosed by the artistic process (active and passive) itself. This involvement, aroused by way of senses, starts with being moved (stimulation, amazement, excitement, and bafflement) ending up in being absorbed (rapture, transport, and surrender). ${ }^{319}$

the biology of belief, New York-Toronto 2002; J. Austin, Zen and the brain: Toward an understanding of meditation and consciousness, Cambridge 1998.

313 A. Huxley, The doors of perception, London-New York 1954; T. Leary, The politics of ecstasy, New York 1968; G. Aghajanian \& G. Marek, 'Serotonin and hallucinogens', in: Neuropharmacology 21 (1999), 165-235.

314 W. Pahnke, Drugs and mysticism: An analysis of the relationship between psychedelic drugs and mystical consciousness, New York 1963.

315 R. Masters \& J. Houston, The varieties of psychedelic experience, New York 1966.

316 Widmer, 'Die angelsächsische Mystikdebatte', 58-59.

317 J. Drane, The McDonaldization of the church: Spirituality, creativity, and the future of the church, London 2000; J. Dewey, Art as experience, New York 1958.

318 J. van der Lans, Kernervaring, esthetische emotie en religieuze betekenisgeving, Nijmegen 1998.

319 C. Benson, The absorbed self: Pragmatism, psychology and aesthetic experience, London 1993. 
Fourthly, something remarkable can happen during the artistic process. Artists call it 'inspiration'. Something that is bigger than the making of the artistic work insinuates itself in the process. There is something which, beyond the limits of the artist, fully employing its methods and skills, animates the work: 'grace' (Jean-Michel Alberola) which in awed respect is experienced as sublime and holy. 320

These creative processes are part of spiritual processes as expressed in devotions, sacraments, reading procedures, icons and other spiritual symbols, understood as processes. Psychologically these symbolizations can be interpreted as 'transitional objects', in the sense of Winnicott, mediating between our 'narcissistic' structure and 'reality'. ${ }^{321}$

Histories. 'We live in stories. And spirituality, certainly, is the story that our soul tells us about ourselves in many forms in which it seeks to become itself amidst the inconstancy, joys, anxieties, and fulfilment of our existence'. ${ }^{322}$ Histories in the interface of spirituality and psychology have two main forms.

The first form is the construction of spiritual autobiographies, facilitated by psychologists. An example is the writing of a spiritual autobiography. Participants write about their experiences, changes, and defeats, trying to articulate their 'spirituality', linked with headings as childhood, adolescence, friendship, spiritual journey, and so on. ${ }^{323}$ Another example is the practice of diary notes. Accompanists ask their clients to bring up their spiritual journey as sincerely as possible over a whole month and every day. The uniqueness of diary notes is their currency: to verbalize the experience that is present at the time of writing and to do that frequently. Diary notes can be used for personal reflection or for a conversation with the accompanist. These constructed 'stories' are frequently used - of course anonymously - in books about spiritual psychotherapy or spiritual accompaniment.

The second form of interdisciplinary research in the area of stories is a psychological reflection on existing spiritual biographies. A paradigm is the study of Kohut on Dag Hammarskjöld's Markings, in which he discovers the transformation of a narcissism which comes to spiritual maturity. ${ }^{324}$ Another example

${ }^{320}$ Art, creativity and the sacred (Ed. D. Apostolos-Cappadona), New York 1989.

321 D. Winnicott, Playing and reality, London 1971; also see G. Provitola, Perfection quest or spiritual quest: Narcissism and its relationship to spiritual discipline, New York 1987.

${ }^{322}$ H. Andriessen, Spiritualiteit als modern verhaal, Nijmegen 1994, 7.

323 Wakefield developed such a course, on the basis of the general course of J. Birren \& D. Deutchman, Guiding autobiography groups for older adults, Baltimore-London 1991.

${ }^{324}$ H. Kohut, Self-psychology and the humanities, New York 1985. 
could be the analysis of the life history of Teresa of Avila by Moyaert, focusing on the tension between the need for God and the desire for God himself. 325

Processes. Psychology has made a major contribution to spirituality by exploring the intra-psychic dimensions of spiritual processes of transformation. To mention only a few attempts.

An essential aspect of spiritual psychology is to get insight in processes of interiorization. Which layers of personality are addressed? What is the inner goal of spiritual practices? What are they aimed at? Are there inconsistencies or even contradictions between the conscious self-ideals and the unconscious needs?326 How to discern between pathological processes and processes of spiritual maturation?327

The concept of 'role' introduced by Sundén in the field of spirituality is interesting. ${ }^{328}$ This concept, derived from the psychology of perception and social psychology, refers not only to behaviours which one takes over, but also to frames of reference which make the perceptions possible, especially important for the perception of God's role.

Inspired by developmental psychology, scholars tried to get insight in spiritual development: stages of transformation, marking points (conversion, repentance, metanoia), moments of relinquishment and surrender, stages which lead to ever deeper and more comprehensive contact with the divine reality. ${ }^{329}$

Finally, we may point at studies which try to translate processes of spiritual transformation as articulated by established spiritual traditions into psychological language games. In this way, Han de Wit aims to make visible the psychological insights and methods found within Buddhistic traditions, describing them as a 'way' with different 'states' of consciousness. ${ }^{330}$ In the same way

325 P. Moyaert, 'Mystiek en liefde', in: J. Walgrave \& P. Moyaert, Mystiek en liefde, Leuven 1988; see also A. Vergote, Religion, belief and unbelief: A psychological study, Leuven-Amsterdam 1997.

${ }^{326}$ L. Rulla, Depth psychology and vocation: A psychosocial perspective, Rome 1971; M. Rulla, J. Ridick \& F. Imoda, Entering and leaving vocation: Intrapsychic dynamics, Rome 1976; D. Vasse, Le temps du désir, Paris 1969.

327 B. Groetschel, Crecimiento espiritual y madurez psicológica, Madrid 1987; C. Mazzoni, Saint Hysteria: Neurosis, mysticism and gender in European culture, Ithaca-London 1996; D. Mihalas, Depression and spiritual growth, Wallingford (PA) 1996; M. Siglag, Schizophrenic and mystical experiences: Similarities and differences, Ann Arbor (MI) 1988.

${ }^{328}$ H. Sundén, Die Religion und die Rollen: Eine psychologische Untersuchung der Frömmigkeit, Berlin 1966; see also J. van der Lans, Religieuze ervaring en meditatie, Deventer 1980.

329 J. Noordzij, Religieus concept en religieuze ervaring in de christelijke traditie: Proeve van een psychologie van de spirituele ontwikkeling, Kampen 1994; R. Bednar \& S. Peterson, Spirituality and self-esteem: Developing the inner self, Salt Lake City (UT) 1990; H. Andriessen, Spiritualiteit en levensloop: Over levensfasen en geestelijke bestemming, Zoetermeer 2006.

${ }^{330}$ H. de Wit, Contemplatieve psychologie, Kampen 1987; Id., De verborgen bloei: Over de psychologische achtergronden van spiritualiteit, Kampen 1995. 
processes in other spiritual traditions are interpreted from a psychological point of view. 331

Relationships. Psychology defines spirituality mostly as an intrapsychic process. This was one of the reasons why spirituality and psychology could not find one another in a fertile interdisciplinarity. Spirituality learned to accept positively the human dynamics in the divine-human relationship. At the same time the factor 'relationship' became more important for psychology. We may observe changes in three areas.

First, the definition of personality became more dialogical. Groundbreaking in this respect is the concept of the 'dialogical self' of Hubert Hermans: a multiplicity of I-positions among which dialogical relations can be established. ${ }^{332}$ This multi-voiced self offers conceptual access to spiritual motives like: the spiritual way, receptivity to otherness, the dynamic concurrence of opposites, the presence of a core experience. 333

Second, some psychoanalytic psychologists redefined mind 'from a set of predetermined structures emerging from inside an individual organism to transactional patterns and internal structures derived from an interactive, interpersonal field'. ${ }^{334}$ This relationality of the human mind, design, intent and implication offers an openness for the understanding of the divine-human-relationship. 335

Finally, for a complete integration of the phenomenon of relationality in an interdisciplinarally conceived spiritual psychology, psychology has to rethink the insights of phenomenology and dialogical thinking, which give the otherness its adequate place within the divine-human relationship. ${ }^{336}$

\section{SPIRITUALITY AND SOCIOLOGY}

Spirituality, sociology (of religion) and social sciences in general have become companions, on a quite natural manner. In the last half of the twentieth century,

331 See, for instance, Z. Halevi, Kabbalah and psychology, Bath 1986; D. Mortazavi, Soufisme et psychologie, Monaco 1989.

332 H. Hermans \& H. Kempen, The dialogical self: Meaning as movement, San Diego (CA) 1993; for a critical evaluation see Culture \& Psychology 7 (2001) no.3.

${ }^{333}$ H. Hermans, 'Het meerstemmige zelf', in: Kansen voor spiritualiteit (Ed. K. Waaijman et al.), Baarn-Nijmegen 1996, 106-123.

334 S. Mitchell, Relational concepts in psychoanalysis: An integration, Cambridge (MA) 1988.

335 Ruffing, 'Personality sciences', 310-311.

336 See C. Keating, Who we are is how we pray: Matching personality and spirituality, Mystic (CT) 1987; J. Nieto, Religious experience and mysticism: Otherness as experience of transcendence, Lanham (MD) 1997. 
the awareness that spirituality is socio-culturally embedded and that community belongs to the heart of spirituality, has opened the minds for sociology of spirituality. On the other side, sociology discovered the last decades a shift in the "religious' landscape: a transition from organized religion into spirituality. ${ }^{337}$ This provoked not only new questions about religion, spirituality and their interaction, but also it caused a stream of interdisciplinary studies in the field of spirituality and social sciences. 338

Disciplines. Till the 1990s, no explicit mention was made of 'spirituality' in the sociology (of religion). The reality of spirituality, however, was touched by scholars like Allport, Berger, Luckmann and others. Gordon Allport had pointed at 'intrinsic' religiosity as reflexive, personalized and individuated, correlated with tolerance, altruism, and social service. ${ }^{339}$ Glock and Stark spoke about the experiential and consequential dimension of religion. ${ }^{340}$ Berger and Luckmann described the phenomenon of creative and personal appropriation from many traditions, the so called individual, unofficial or lived religion. ${ }^{341}$

In the 1990s the sociology of religion began to veer toward an explicit look at spirituality. One of the major themes in sociological research of spirituality is the presupposed dichotomy between religion and spirituality. Organized religion is depicted as cut and dry, encrusted and culturally bound. Spirituality is conceived as giving expression to one's own being. It is associated with feelings and power that comes from within, with the deepest self and what is sacred in us. ${ }^{342}$ Uncritically, spirituality is conceived as non-intellectual, anti-institutional, personal and experiential, preparing the consecrated phrase 'I am spiritual but not religious'. Reality is however more complicated.

First, what happens in the field of spirituality and religion is a change in the field of the sacred: from images of dwelling to images of seeking. ${ }^{343}$

\footnotetext{
337 Paul Heelas et al., The spiritual revolution: Why religion is giving way to spirituality, MaldenOxford-Carlton 2005.

338 J. Coleman, 'Social sciences', in: The Blackwell companion to Christian spirituality (Ed. A. Holder) Malden-Oxford-Carlton, 289-307; C. Wolfteich, 'Spirituality and social sciences', in: The new SCM dictionary of Christian spirituality, 68-73; H. Knoblauch, 'Soziologie der Spiritualität', in: Handbuch Spiritualität, 91-111.

339 G. Allport, The individual and his religion: A psychological interpretation, New York 1950.

${ }^{340}$ C. Glock \& R. Stark, Religion and society in tension, Berkeley 1965.

${ }^{341}$ P. Berger, The heretical imperative, New York 1979; T. Luckmann, The invisible religion, New York 1967.

342 W. Roof, A generation of seekers, San Francisco 1993; Id., The spiritual marketplace: Baby boomers and the remaking of religion, Princeton (NJ) 1999.

${ }^{443}$ R. Wuthnow, After heaven: Spirituality in America since the 1950s, Berkeley 1998.
} 
Second, too little attention has been paid to the nexus between spirituality and social service and advocacy, bringing to the fore important elements like a holistic sense, discernment, empowerment and experiences of transcendence. ${ }^{344}$

Third, a majority says to be 'religious and spiritual' and expresses their spirituality in continuity with their religiosity. ${ }^{345}$

Lastly, the conceptualisation should be put in a broader historical and theological-philosophical framework. ${ }^{346}$ It needs a further theoretical reflection on key concepts like: spirituality, religion, religiosity, unchurched people, organized spirituality, immanent, transcendent, and so on. ${ }^{347}$

Theories. In sociology a variety of perspectives has been adopted, each of them offering an interdisciplinary entrance for spirituality. We mention three perspectives.

First, the structural perspective examines the way in which a society is organized as a system, with a specific attention for the basic structures, such as economy, politics, government, security apparatus and so forth. To the same system belong also, in a different way, education, health care, religious institutions, and the cultural sector. Particularly, the liberation spirituality locates itself within this social system, developing spiritual practices on the basis of social analysis and the dangerous memory of the Christian tradition. ${ }^{348}$ The same structural perspective has been chosen by other forms of emancipation spirituality: eco-spirituality, peace-spirituality, feminist spirituality, and so on.

Second, the value-perspective studies the symbols, ideas, virtues, and convictions which give unity, cohesion, and meaning to social systems on all levels. ${ }^{349}$ Spirituality tries to discern between the articulated and the hidden values-orientations influencing the conduct and life of people. Max Weber, for example, has shown how Calvinistic piety in fact, can be an important ingredient in 'the spirit of capitalism'. ${ }^{350}$ The stress on asceticism and self-sanctification in Catholic

${ }^{344}$ G. Stanczak \& D. Miller, Engaged spirituality: spirituality and social transformation in mainstream American religious traditions, Los Angeles 2002.

${ }^{345}$ P. Marler \& K. Hadaway, 'Being religious and being spiritual in America: A zero-sum proposition?' in: Journal for the Scientific Study of Religion 41 (2002), 289-300; B. Zinnbauer et al., 'Religion and spirituality: Unfuzzing the fuzzy', in: Journal for the Scientific Study of Religion 76 (1997), 549-564.

346 R. Fuller, Spiritual but not religious: Understanding unchurched America, New York 2001.

347 See, for instance, D. Helminiak, The human core of spirituality, Albany (NY) 1996.

348 G. Gutiérrez, We drink from our own wells: The spiritual journey of a people, Maryknoll (NY), 1984.

${ }^{349}$ P. Berger \& B. Berger, Sociology: A biographical approach, New York 1972; P. Berger, The sacred canopy, Garden City (NY) 1967.

${ }^{350}$ M. Weber, The Protestant ethic and the spirit of capitalism, New York 1958; see also D. McClelland, The achieving society, Princeton 1961. 
Spirituality, in the last three centuries, is highly propelled by a culture of autonomy, self-development, profit and progress.

The actor-perspective looks at society from the viewpoint of the participants in a social situation. Social structures and values are as such not observable. They only become visible in actions, thoughts and speech of people who perform these structures. This perspective has been discovered and developed in the symbolic interactionism of George Herbert Mead ${ }^{351}$ and ethno-methodology. ${ }^{352}$ The actorperspective in spirituality articulates the ways in which people try to live through the divine-human relationship in their everyday-life. 353

From the viewpoint of spirituality, the integration of the three sociological approaches is essential. Spirituality as a phenomenon is precisely the interaction between values and participants, within a socio-cultural context. ${ }^{354}$

Professions. From a sociological point of view, we may differentiate between the various layers, making up the whole of the socio-cultural context, in which spiritual practices and professions appear.

The most comprehensive context is the 'mentality': the language of the time, 'what the spiritual man takes seriously; it is in this very cultural situation that his yearnings and his predicament "take flesh"; it is through this medium that he finds God, yet ever seeks him'. ${ }^{355}$

Looking at Western culture from this perspective one could, for example say that this culture is in transition: from a culture dominated by fixed role patterns (life as) into a culture lead by personal options and ideals (subjective life), 356 giving way to spirituality 357 without accepting however the dogma of 'spiritual but not religious'. Another 'cultural' mentality is the search for new roles for the body and gender in spirituality and a greater mixing of codes across traditions. ${ }^{358}$

351 G. Mead, Mind, self and society, Chicago 1934.

352 H. Garfinkel, Studies in ethnomethodology, Englewood Cliffs (NJ) 1967; E. Goffman, The presentation of the self in everyday life, Garden City 1959.

353 G. van Tillo, Onthullingen: Spiritualiteit sociologisch benaderd, Amsterdam-Tilburg 1994; H. Knoblauch, 'Transzendenzerfahrung und symbolische Kommunikation: Die phänomenologisch orientierte Soziologie und die kommunikative Konstruction der Religion', in: Religion als Kommunikation (Hrsg. T. Hartman e.a.), Würzburg 1998, 147-186; Idem, 'Soziologie der Spiritualität'.

354 O. Steggink \& K. Waaijman, Spiritualiteit en mystiek: 1. Inleiding, Nijmegen 1985, 79-108.

355 M. de Certeau, 'Cultural and spiritual experience', in: Spirituality in the secular city, New York 1966, 9; see also Lamplighters: Exploring spirituality in new contexts (Ed. B. Flanagan \& D. Kelly), Dublin 2004.

356 C. Taylor, Varieties of religion today, Cambridge 2002.

357 Heelas e.a., The spiritual revolution.

${ }^{358}$ M. McGuire, 'New-old directions in the social scientific study of religion: Ethnography, phenomenology and the human body', in: Personal knowledge and beyond (Ed. J. Spikard e.a.), New York 2002, 195-212. 
A second layer is the macrosocial context: the society as a whole, organized politically, militarily, juridically, administratively, and religiously. The social climate on a macrosocial scale is determined by the nature of processes occurring within and between the different levels of organisation. On a macrosocial level, one may observe an increasing interest in the spirituality of the city: the spiritual dimensions of city-making and urban living, the experiences of the longterm residents in inner cities, the opportunity for human community, and so on. ${ }^{359}$

A third layer is the micro-meso-context. This level encompasses the smallscale social fabric of a family, commune, religious community, or action group. These communities are sustained by a sense of connectedness, a climate in which the individual members can express themselves personally. ${ }^{360}$ In liberation, emancipation and struggle spirituality such 'small groups' flourish as social contexts to support the spiritual quest. ${ }^{361}$

The last layer is the personal role, the smallest and most immediate context. Some of the roles are assigned by birth, others are instilled in us by way of a socialisation process, still others can be acquired by training. For spirituality, the most important thing is, to find the role which is in accordance with my destiny and vocation. This asks for a critical spiritual accompaniment. ${ }^{362}$

The interdisciplinarity between sociology and spirituality can on the one hand sharpen the insight in the differentiation of the social context and the cohesion between the different layers, but at the other hand it can provide a concrete embedment for the orientation on the divine-human transformation.

Words. Social sciences do not simply registrate the language people use for 'spirituality'. They produce partly the vocabulary they like to hear, a 'new vocabulary' that emphasizes the immanence of God, stresses experience, honours the body, is sensitive to gender differences, and so on. 'The new values emphasize self-fulfilment and self-growth; inner spiritual discovery and exploration; a greater sense of self; appreciation of the body, of gender and spirituality; of reaching out to others and letting go'. ${ }^{363}$ One perceives in the phraseology immediately the modern prepossessed attitude, over against the disapproval of the

359 B. Flanagan, The spirit of the city: Voices from Dublin's liberties, Dublin 1999; P. Sheldrake, Spaces for the sacred: Place, memory and identity, London 2001; Spirituality in the city (Ed. A. Walker), London 2005; J. Pearce \& A. Pearce, Inner city spirituality, Nottingham 1987.

360 'Kleine groep: Een leefmogelijkheid', in: Speling 27 (1975) no.1 (special issue).

361 C. Wolfteich, 'Spirituality and social sciences', 69-70; see also R. Wuthrow, Sharing the journey: Support groups and America's new quest for community, New York 1994.

362 C. Gratton, The art of spiritual guidance, New York 1993; K. Fischer, Women at the well: Feminist perspectives on spiritual direction, New York 1991.

363 Roof, A generation of seekers, 47. 
'old-fashioned' language of religion. In this way, a dichotomy between spirituality and religion (and a pejorative tint to the latter) is introduced. ${ }^{364}$ Moreover, the more 'difficult' aspects of spirituality - interior discipline, the complex practice of contemplation - remain out of the picture. The conclusion of McGuire is right: 'It is useful for sociologists who claim to be studying spirituality, to challenge their own operative definitions of spirituality'. ${ }^{365}$ It needs a semantic reflection on the vocabularies used in social-scientific research. "Here the challenge to the social scientists is to go by and the often crude and simplistic indices of spirituality frequently found in survey research to the deeper ethnographic, "thick descriptions" of lived spirituality'. ${ }^{366}$

Things. Structural analysis deciphers the ways in which spiritual schools and movements are connected with the infrastructure of society: economy, politics, security apparatus and government, on a national and a global level. Inspired by Marxist analysis and listening to the lowest strata of society - the 'preferential option for the poor' - liberation spiritualities established a powerful argument for the relevance of political and economical analysis with regard to spirituality, reframing spirituality in terms of human solidarity, structural critique and political transformation by and for the sake of the oppressed'. ${ }^{367}$

The structural perspective on society has been systematically developed by the spirituality of liberation. ${ }^{368}$ Thus Casaldáliga and Vigil's 'handbook' describes spirituality as the universal human passion for contemplation in liberation, opting for the most oppressed people and expressing itself in a praxis of liberation, propelled by the reign of God. ${ }^{369}$

The same structural perspective has been adopted by all forms of emancipation or liberation spirituality. Feminist spirituality opposed the structural inferiority of women vis-à-vis the man dominated higher, oppressive positions, including the underlying spiritual dichotomies (spirit-body, rational-intuitive, intelligence-emotion etc.) and the one-sided male version of God. ${ }^{370}$ In a comparable way, homo

\footnotetext{
364 See Zinnbauer et al., 'Religion and spirituality'.

365 M. McGuire, 'Review of Sarah Coakley "Powers and submission: Spirituality, philosophy and gender" (Oxford 2002)', in: Journal for the Scientific Study of Religion 42 (2003), 301.

366 Coleman, 'Social sciences', 305.

367 Wolfteich, 'Spirituality and social sciences', 72.

${ }^{368}$ Gutiérrez, We drink from our own wells; S. Galilea, The way of living faith: A spirituality of liberation, San Francisco 1988; J. Sobrino, Spirituality of liberation: Toward political holiness, New York 1988; E. Bonin, Spiritualität und Befreiung in Latein Amerika, Würzburg 1984.

369 P. Casaldáliga \& J. Vigil, Political holiness: A spirituality of liberation, New York 1994.

${ }^{370}$ M. Boyer, Biblical reflections on male spirituality, Collegeville (MN) 1996; A. Carson, Feminist spirituality and the feminine divine: An annotated bibliography, Trumansburg (NY) 1986; Feminist voices in spirituality (Ed. P. Hegy), Lewiston (NY) 1996; C. Fischer, Of spirituality:
} 
spirituality unveils the dominance of hetero perspectives, ${ }^{371}$ as black spirituality unmasks white arrogance and discovers its own roots. ${ }^{372}$ An important dimension of the structural perspective is the relation between socio-political systems and the eco-systems. Ecological spirituality examines the network of causes that is responsible for the pollution of elements and the exhaustion of the earth, searching for a way out of this deteriorization of the ecosphere. ${ }^{373}$

Last but not least, the spirituality of the peace movement analyses the military-industrial complex, in seeking practical ways to escape from the horror of war and violence. ${ }^{374}$

Images. An interesting bridge between art and spirituality has been constructed by Robert Wuthnow. In his research he interviewed artists and discovered, that they were driven to explore. ${ }^{375}$ Their spirituality involved attention, centeredness, and awareness. They emphasize the importance of sustained practice: 'If there is a single key to artist's perspectives on the spiritual, it is this: spirituality like art, must be practiced to be perfected. The way of the artist involves doing, rather than only believing in the possibility of doing. It requires training, discipline and a considerable investment of oneself'. ${ }^{376}$ The artist as a paradigm for spirituality 377 is an eye opener for what contemporary spirituality may be: not only feelings and ideas, but also discipline, practice and self-investment.

In a second study, Wuthnow explores those people in his national random sample (23 percent) who say to invest in spiritual growth and to engage in sustained

A feminist perspective, Lanham (MD)-London 1995; A. Schulenburg, Feministische Spiritualität: Exodus in eine befreiende Kirche? Stuttgart 1993; The spiritual path: Explorations in women's spirituality (Ed. T. King), St. Paul (MN) 1992; C. Wolfteich, Navigating new terrain: Work and women's spiritual lives, New York 2002.

371 J. Fortunato, Embracing the exile: Healing journeys of gay Christians, San Francisco 1984; D. James, What are they saying about masculine spirituality? New York 1996; M. Thompson, Gay spirit, myth and meaning, New York 1987.

372 G. Huizer, Folk spirituality and liberation in Southern Africa, Talence (France) 1991; P. Paris, The spirituality of African peoples, Minneapolis 1995.

373 J. Cobb, Sustainability, economics, ecology and justice, New York 1992; H. Kessler, Das Stöhnen der Natur: Plädoyer für eine Schöpfungsspiritualität und Schöpfungsethik, Düsseldorf 1990; A. Primavesi, From Apocalypse to Genesis: Ecology, feminism and Christianity, Wellwood 1991; D. Dorr, Integral spirituality: Resources for community, justice, peace and the earth, Maryknoll (NY)Dublin 1990; M. Fox, Creation spirituality: Liberating gifts for the people of the earth, San Francisco 1991.

374 'Zoek de vrede en jaag die na', in: Speling 41 (1989) no.3 (special issue); 'The struggle for peace', in: The Way 22 (1982) no.1-4 (special volume).

375 R. Wuthnow, Creative spirituality: The way of artists, Berkeley 2001.

376 Ibid., 101.

377 See B. Borchert \& K. Waaijman, 'Raakvlakken tussen spiritualiteit en kunst', in: Speling 40 (1988) no.3, 5-19. 
practice. ${ }^{378}$ It appeared that a majority of them (more than 70 percent) participates in religion. Organized religion and spirituality are not in competition. 'The new bromide suggested by Wuthnow's data runs something like this: "I am serious about spirituality (and practice it regularly and show concern about spiritual growth) and therefore, I am also religious"'. ${ }^{379}$

Texts. As an empirical science, sociology (of religion) is not interested in 'texts' in the sense that it cherises a specific corpus of texts. Of course, sociology has 'important' writers like Marx, Weber, Allport, Berger, Luckmann, Habermas, and others. But these texts are not object of careful exegesis.

Sociology constructs texts, as spiritual psychology does: documents of life. ${ }^{380}$ One may observe a variety of document registration or construction.

In the naturalistic inquiry, investigators are charged to free themselves from preconceptions so as to better see and understand the lived experience of which they have become active students. ${ }^{381}$

The sociological interview is a face to face verbal interchange in which the researcher attempts to elicit information or expressions of convictions or belief from another person or persons, standardized in different ways. ${ }^{382}$

Registration of an experiment, bringing people together into an experimental setting, for instance a weekend in an abbey or in a biblio-drama. The scholar is interested in the interactions between the participants. 383

The social survey is the systematic collection of data from populations or samples, the use of interview and/or the self-administered questionnaire. ${ }^{384}$

All these forms of sociological research - one may add the field method, the biographical method, the audio-visual methods of film and photography ${ }^{385}-$ depend on one critical point: do they focus on the core of spirituality, the divinehuman transformation?

Histories. The history of spirituality can shed light on the diachronicity of spiritual histories, sociology can illuminate the synchronicity of the same phenomenon.

\footnotetext{
378 R. Wuthnow, All in sync: How music and art are revitalizing American religion, Berkeley 2003.

379 Coleman, 'Social sciences', 297-298.

${ }^{380}$ K. Plummer, Documents of life: An introduction to the problem and literature of a humanistic method, London 1983.

${ }^{381}$ H. Blumer, Symbolic interactionism, Englewood Cliffs (NJ) 1969.

382 J. Douglas, Creative interviewing, Beverly Hills 1985.

${ }^{383}$ M. Katovich, 'Symbolic interactionism and experimentation: The laboratory as a provocative stage', in: Studies in Symbolic Interaction 5 (1984), 49-67.

384 S. Lieberson, Making it count: The improvement of social research and theory, Berkeley 1985.

385 N. Denzin, The research act: A theoretical introduction to sociological methods, Englewood Cliffs (NJ) 1989.
} 
To create this synchronic picture, the sociology (of religion) needs sources. From the perspective of spirituality an important source is the collection of biographical data. ${ }^{386}$ 'People write diaries, send letters, take photos, write memos, tell biographies, scrawl graffiti, publish their memoirs, write letters to the papers, leave suicide notes, inscribe memorial and tombstones, shoot films, paint pictures, make music, and try to record their personal dreams. All of these expressions (...) are documents of life'. ${ }^{387}$ The biographical method (in social sciences) as the study of spirituality, attaches great value to personal documents in as much as they enable the researcher to listen to people's experiences as they are interpreted by these people themselves.

Biographical studies are an important development in the interdisciplinary field of social sciences and spirituality. In the history of spirituality, a great many spiritual (auto)biographies have been preserved. In our time, spiritual (auto)biographies are written in a comparable way. This is precious material since it can help us to gain insight into the spiritual way people are travelling in our day. The writings of Etty Hillesum, Hammarskjöld, Anne Frank, Libanio Christo and many others are biographical data giving insight in contemporary spirituality. Biographical research in the field of spirituality is growing. ${ }^{388}$

Processes. One of the dilemmas of the sociology of spirituality is: affirming the mainstream of 'new' spirituality as it is uncritically recorded in surveys, or looking deeper into those seekers who try to go their way - inside or outside religion - by dedicated practice and discipline, oriented on the 'sacred'.

Roof articulated in his A Generation of Seekers his initial definition of spirituality in these phrases: 'Spirituality gives expression to the being that is in us. It has to do with feelings, with the power that comes from within, with knowing our deepest selves and what is sacred in us. ${ }^{389}$ This conceptualization is self-centred, strongly emphasizing feelings. This is not untrue, but one-sided. The outcome that this type of spirituality is moving away from organized religion (and organized spirituality), is a self fulfilling prophecy. The hypothesis focuses on a

\footnotetext{
386 See Plummer, Documents of life. For the life (hi)story method or the biographical method see: Denzin, The research act, 182-209.

387 Plummer, Documents of life, 13.

388 See Religion und Biographie: Perspektiven zur gelebten Religion (Hrsg. A. Grözinger \& H. Luther), München 1987; Wer schreibt meine Lebensgeschichte? Biographie, Autobiographie, Hagiobiographie und ihre Entstehungszusammenhang (Hrsg. W. Sparn), Gütersloh 1990; S. Klein, Theologie und empirische Biographieforschung: Methodische Zugänge zur Lebens- und Glaubensgeschichte, Stuttgart 1994; H. Knoblauch, Qualitative Religionsforschung: Religionsethnographie in der eigenen Gesellschaft, Paderborn 2003; W. Drechsel, Lebensgeschichte und Lebens-Geschichten, Gütersloh 2002.

389 Roof, A generation of seekers, 64.
} 
non-processual spirituality. Processual spirituality - the divine-human transformation - is not only expression of our being, or feeling, or power from within, or self-knowledge, but also appropriation, practice, alterity, community and service.

The other way chooses Wuthnow appealing to the notions practice and discipline. Practice and discipline imply intentionality, deep self-reflection, devotion of time and effort to prayer and meditation, discernment and interiorization. ${ }^{390}$ This conceptualization does not seem to privilege either seeker spirituality or religiously grounded spiritualities. Spirituality as practice and discipline can be performed inside and outside religions.

A critical sociology of spirituality presents both sides of the dilemma: the more eclectic and consumerist spirituality and the more disciplined spirituality, both present in our culture, inside and outside religion. The two-sidedness of the dilemma provokes the notion of discernment, a core category in all spiritual traditions: 'Discernment may challenge an easy eclectic individualism in spirituality, a feel-good spirituality-lite or a consumerist attitude toward spiritual practices, which sociological studies show is very rampant in contemporary American culture'. ${ }^{391}$

Relationships. The root metaphor of 'social sciences' and 'sociology' is socius, companion. It is, therefore, not strange that 'relationality' in culture and society is the focus of social sciences. The field of spirituality during the last decades was a shift from more individualistic piety into the direction of community spirituality. It is quite natural, that sociology and spirituality developed a strong interdisciplinarity given this common interest. We may distinguish four levels of common grounds.

The first level is the awareness of contextual embeddedness of spirituality: 'Spirituality does not exist in a vacuum. Social, cultural, economic, and political contexts shape how one understands oneself, the world and the divine. Indeed, context moulds the practice of faith. The social sciences are vital tools for understanding the context of individual's and communities' spiritual lives'. ${ }^{392}$ Social contexts and spirituality are companions.

The second level is more interior. Spirituality is not only socially embedded, but also the performance of spirituality itself is communal. Community is the means in and by which (medium in quo) spirituality grows. This precisely is typical for the post Vatican II period. 'One of the most significant developments in the late twentieth century has been the development of small faith

\footnotetext{
390 Wuthnow, After heaven.

${ }^{391}$ Coleman, 'Social sciences', 305.

392 Wolfteich, 'Spirituality and social sciences', 68.
} 
communities. There are numerous expressions of this impulse that brings Christians together weekly in small groups for reflection on Scripture, shared prayer, community and ministry, often directed towards the poor'. ${ }^{393}$ Particularly the basic Christian communities are to be mentioned (circa 180.000 in Latin America alone). ${ }^{394}$ Community and spirituality are intrinsic companions, giving shape to one and the same process of transformation. ${ }^{395}$

The third level: spirituality is not only embedded and performed in communities, it is also aiming at community. Rightly states Wolfteich: 'Christian spirituality is not a purely individual affair, isolated from human relationships. Rather, social context, social dynamics and social institutions all effect spirituality. (Although it should be pointed out that so too can spirituality influence society)' ${ }^{396}$ The last sentence between brackets is important. On micro, meso and macro level, we observe how spirituality brings people together and bounds together. Community is one of the fruits of spirituality.

The fourth level: inter-human community mediates the communion with God, who in Himself is a triune community. 'Human relationships of all spheres of life are to be brought into conformity with the equality, mutuality and interdependence that characterize the divine life. (...) From the perspective of Trinity as interpersonal communion, human life in Christ by the Spirit is a call to loving communion with God, others and every living creature' ${ }^{397}$ Human social life is a spiritual companion of the divine triune life.

The four levels belong together and permeate one another. Too much stressing on the contextuality (level 1) can frustrate the spiritual depth of the divinehuman transformation (level 2-4).

\section{SPIRITUALITY AND EDUCATION}

From the 1980s one may observe a worldwide scholarly interest in the field of spirituality and education, ${ }^{398}$ mainly propelled by the policymakers in the area of education, as can be illustrated by the Education Acts of 1944 and 1988 in the

\footnotetext{
${ }^{393}$ T. Rausch, 'Community', in: The new SCM dictionary of Christian spirituality, 204.

394 B. Lee, The Catholic experience of small Christian communities, New York 2000.

${ }^{395}$ M. Frohlich, Mystical transformation: Intersubjectivity, and foundations, Ann Arbor (MI) 1990.

396 Wolfteich, 'Spirituality and social sciences', 69.

${ }^{397}$ M. Downey, 'Trinity and spirituality', in: The new SCM dictionary of Christian spirituality, 625. See idem, Altogether gift: A Trinitarian spirituality, Maryknoll (NY) 2000.

398 M. Chater, 'Child and youth spirituality: Current research and practice issues, and some strategic pointers', in: Studies in Spirituality 15 (2005), 251-253.
} 
United Kingdom. ${ }^{399}$ In a sense, the field of research education and spirituality was hijacked by the self-imposed compulsion to arrive an universal definition of spirituality, avoiding every critic of religious and secularized groups. The self-imposed neutrality was a practical position, halfway loose vagueness and over-prescriptive exclusivity, the midst of the extremes of dogmatism, secularism and rationalism.

Disciplines. The imprisonment by practice and politics blocked independent thinking about the establishing of the (sub)discipline education and spirituality. What is spirituality? What is education? How are they related? Included are, of course, questions about religious traditions and so-called 'modern experience'.

But these questions should not dominate the scene. From the viewpoint of a discipline, the first point to solve is: how to establish the object? What may be the 'spiritual' in 'education', and how to distinguish this area from the emotional, religious, and moral domain?

Meanwhile, an increasing stream of publications can be observed, linked with congresses and journals, ${ }^{400}$ with research and study programs. ${ }^{401}$ Difficulties in defining the object are itemized and groundbreaking evaluations are made, concluding that the definition issue makes it hard to give a coherent shape to the discipline education and spirituality. 402

Theories. The last decades, a wide range of approaches to and concepts of spiritual education are presented. Within this wide range of approaches the theoretical positions, however, are limited to two main areas.

On the one hand, theories are conflicting with the dominant educational systems in western societies, qualified educational policies of science and modernity stressing technics and rationality. ${ }^{403}$ In these approaches spirituality is basically seen as corrective force against technocratic and rationalist education policy.

On the other hand, theories are conflicting with religious traditions, mostly qualified as juridical dogmatism, in favour of religiously secularized, pluralist

\footnotetext{
399 Spirituality and the curriculum (Ed. A. Thatcher), London 1999.

400 See for instance Education, spirituality and the whole child (Ed. R. Best), London 1996, a report of the congress under the same title. See also International Journal of Children's Spirituality.

401 See C. Erricker, J. Erricker, C. Ota, D. Sullivan \& M. Fletcher, The education of the whole child, London 1997, linked with the research program 'Children and Worldviews Project'. See also R. Coles, The spiritual life of children, Boston 1990. Regarding study programs, see 'Spirituality Studies at the Institute of Religious Education' (Boston).

402 Chater, 'Child and youth spirituality'.

${ }^{403}$ See J. Cuttingham, 'Spirituality, science and morality', in: Spirituality, philosophy and education (Ed. D. Carr \& J. Haldane), London-New York 2003, 40-54; see also B. Hyde, 'The plausibility of spiritual intelligence: Spiritual experience, problem solving and neural sites', in: International Journal of Children's Spirituality 9 (2004) no.1, 39-52.
} 
and non-fundamentalist alternatives, searching for the 'spirituality of a child' as an universal archetype. ${ }^{404}$

These theories move the spiritual away from religious traditions, to gain a broad plausibility. In fact, this tendency, looking for an underlying consensus beyond religion and traditional lifestyles, caused an alienation from spiritual traditions. A specific implication is the omitting of every reference to 'God' as source of values and spiritual growth. Interesting is, that philosophical 'traditions' tend to fill up this vacuum, to discover a 'non religious spirituality'. 405

It needs a critical evaluation of these two main streams of conceptualising spirituality and education. ${ }^{406}$

Professions. The educational praxis is strongly focused on the curriculum, the child and its imaginative world as a kind of universal archetype. Meanwhile, the role of the teacher is also perceived, particularly on the level of attitudes: protecting the affective and creative in children; noticing their lives in the world; putting their praxis in dialogue with spiritual traditions; asserting a life beyond skills; leading pupils beyond half-truths and narrow-mindedness; providing a climate to know the every day life and to encounter the unknown, and so forth. 407

Needed however is not only a role concept of the teacher on the level of praxis and attitude, but also on the level of self-reflection and introspection. Scholars speak about the spirituality of children and about spiritual programs, but who will conduct these programs? ${ }^{408}$ Chater rightly states:

Practitioners and theorists should also ask themselves why they are interested in spirituality. If they are truthful users of non-cognitive forms of knowledge, alongside the rational, they should seek in their own early lives some experiences which lead them to be exponents of the spiritual life in learning. (...) They should frequently interrogate themselves, and each other, about the extent to which their spiritual agenda is shaped by their personal attitudes to religion or to education, and they should check these attitudes against what we know of the lives of children and young people now. ${ }^{409}$

\footnotetext{
404 See C. Jung, 'The psychology of the child archetype', in: The collected works of C. G. Jung (Ed. H. Read, M. Fordham \& G. Adler), London-Princeton 1959, vol. 9, 151-181; D. Hay \& R. Nye, The spirit of the child, London 1998.

405 Spirituality, philosophy and education.

406 See again Chater, 'Child and youth spirituality'.

407 T. Groome, Sharing faith, San Francisco 1991; Id., Educating for life: A spiritual vision for every teacher and parent, Allen (TX) 1998; P. Palmer, To know as we are known: Education as a spiritual journey, San Francisco 1983.

${ }^{408}$ D. Vokey, 'Longing to connect: Spirituality and public schools', in: Spirituality, philosophy and education, 174-177.

${ }^{409}$ Chater, 'Child and youth spirituality'.
} 
Words. As every area of spirituality, the area of education and spirituality has its own vocabulary. There are, of course, the nouns articulating the participants in spiritual education: pupil, child, student, teacher, educator, coach, tutor, formator, pedagogue and so on. There are also the verbs articulating the process, such as: upbring, educate, teach, learn, initiate, guide, etc. Deeper insight in these basic categories and the words surrounding them is necessary. To give just one example. The term 'development' is frequently used reflecting on the Education Acts in 1944 and 1988 in the UK. ${ }^{410}$ But does not introduce this word 'development' - unreflectedly - an attitude of instrumentalism and production in education and spirituality? ${ }^{311}$ How does it relate to words like growth, change, conversion, journey, and transformation?

It needs a critical description of the basic words in the field of education and spirituality, from a semantic, historical and socio-cultural perspective, describing not only their content, but also their contextual connotations and their function in the spiritual and educational language games.

Things. The discussions on education and spirituality are strongly theory-oriented because the policymakers want a neutral area, away from religion and technocratic rationalism. Meanwhile, some presuppositions are pressed in the background.

One of these presuppositions is the socio-political implication. To give one example: the search for a broad and neutral concept of spirituality may be propelled by a liberal pluralist society, tending toward the secular value of personal well being and self-development, a solid preparation for self-determination, self-expression and autonomy. The critical question is, however, whether a consensual, individualistic and a-traditional spirituality is not at the service of a competitive, global economy. ${ }^{412}$ In the same way 'development' reflects a capitalist spirit, having the connotation of a linear movement of enlargement and economic growth. ${ }^{413}$

Another presumption is the idea of an unearthly 'spiritual' world. An example: the UK government defined, after the Education Acts of 1944 and 1988, the 'spiritual' as an awareness of things beyond the immediate and material, as the

410 See for instance M. McGhee, 'Making spirits attentive: Moral and spiritual development', in: Spirituality, philosophy and education, 26-39.

411 See J. Hull, 'Human development and capitalist society', in: Stages of faith and religious development: Implications for church, education and society (Ed. J. Fowler, K. Nipkow \& F. Schweitzer), London 1992, 209-223.

$412 \mathrm{~J}$. Hull, 'The ambiguity of spiritual values', in: Values in education and education in values (Ed. M. Halstead \& M. Taylor), London 1996, 33-44.

${ }^{413}$ Hull, 'Human development and capitalist society'; see also id., 'Competition and spiritual development', in: International Journal of Children's Spirituality 6 (2001) no.3, 263-276. 
recognition and valuing of a non-material dimension of life. ${ }^{414}$ This dichotomy between the 'material' and the 'non-material', constructed by political thinking, is in fact the expulsion of spirituality from the socio-cultural reality, which is precisely the opposite of an incarnational spirituality, promoted by 'traditional' spiritualities, perceiving the profane as a locus of spirituality. 415

Images. For centuries, paintings, sculptures, and stain glass mediated for participants the essence of spirituality. Central spiritual teachings were expressed and interiorized musically in temples, synagogues, churches and mosques. Classical education encompassed not only 'sciences' but also 'arts'.

Modern education became dominantly cognitive. Although some elements of artistic expression are integrated in the educational system, the great majority of means and goals is cognition-oriented. Moreover, real implementation of modern art can be dangerous, because it is undermining the repressive overlay of education. ${ }^{416}$ Within the area of spirituality and education, some voices are heard, advocating for a combination of the 'spiritual' in education with arts and symbols. ${ }^{417}$ Drama, music, and poetry can make 'spirits attentive'. ${ }^{418}$ And 'metaphors' can play an important role in learning processes, as exercises of imagination regarding spiritual reality. ${ }^{419}$

Texts. The field of education and spirituality has produced a number of classical writings, from Aboth in Mishnaic times to Buber's Über das Erzieherische, from John Chrysostom's An Address on Vainglory and the Right Way for Parents to Bring up their Children to Education at the Crossroads of Jacques Maritain, from Comenius to Dewey, Fröbel and Montessori.

Till now, these rich traditions of spiritual-educational writings have not led to the establishment of a representative collection of texts in the area of spirituality and education, neither has been attempted to comment these texts from a spiritual-educational perspective nor developed a specific hermeneutic in this

${ }^{414}$ Education for adult life: The spiritual and moral development of young people (Ed. The School Curriculum and Assessment Authority), London 1996.

415 B. Butler \& T. Butler, Just spirituality in a world of faith, London 1996.

416 D. Freedberg, The power of images: Studies in the history of response, Chicago-London 1989.

$417 \mathrm{~J}$. Broadbent, 'Embodying the abstract: Enhancing children's spirituality through creative dance', in: International Journal of Children's Spirituality 9 (2004) no.1, 81-96; A. Trousdale, 'Black and white fire: The interplay of stories, imagination and children's spirituality, in: International Journal of Children's Spirituality 9 (2004) no.2, 177-188; L. van Aalsum et al., Verhalen om het Geheim: Levensverdieping in het primair onderwijs, 's-Hertogenbosch 1998.

${ }^{418}$ McGhee, 'Making spirits attentive'.

${ }^{419}$ M. Halstead, 'Metaphor, cognition and spiritual reality', in: Spirituality, philosophy and education, 83-96. 
field, giving depth to discussions concerning the discipline at stake, the theoretical background and the professional implications.

Histories. It needs deeper historical insight in the main traditions in the area of spirituality and education. We shall pass in review a number of them.

Firstly, the house of study (bet hammidrash), grounded in biblical times, being the centre of Jewish spirituality. Students are initiated in the large area of countless rabbis, mentioned by name, who in fierce disputes discussed the themes important for the halacha. This tradition is on the background of dialogical models of education and spirituality. 420

Secondly, the educational model of Christian spirituality, such as education and formation within the Modern Devotion ${ }^{421}$ and the upbringing and education of youth in orders and congregations, ${ }^{422}$ strongly personalistic oriented. The central value is the uniqueness of the person, connected with and responsible for the other, and open to God in whose image the person is created. ${ }^{423}$

Thirdly, holistic education, criticizing the Enlightenment model, fuelled by philosophical idealism ${ }^{424}$ strongly focussed on autonomy and technological rationality. Holistic education seeks to be comprehensive, searching for an affective and aesthetic counterweight, fuelled by Romantic spiritualities, counterpart of the Enlightenment, but part of the same Modernity project. ${ }^{425}$ Influential thinkers in this holistic stream are Comenius, Dewey, Whitehead, Montessori, Fröbel and Steiner. In the centre is 'the whole child'.

Processes. Very generally formulated education can be understood as a learning process that brings students home in the actual world by understanding it and by knowing how to find meaning in it. ${ }^{426}$ But the critical question is: what in

${ }^{420}$ M. Buber, 'Über das Erzieherische', in: Schriften zur Philosophie, Werke I, München 1962, 787-808; H. Schrey, Dialogisches Denken, Darmstadt 1983; Zur Geschichte des Dialogs (Ed. M. Meyer), Darmstadt 2006; A. Wright, 'The child in relationship: Towards a communal model of spirituality', in: Education, spirituality and the whole child, 139-149.

421 A. Weiler, 'Onderwijs en vorming bij de Moderne Devotie', in: Speling 45 (1993) no.3, 14-22.

422 M. Sauvage, 'Ordres enseignants', in: Dictionnaire de spiritualité, Paris 1982, vol. 11, 877-901.

423 T. Andree, Geschapen naar Gods beeld, Utrecht 1991; J. Ungoed-Thomas, 'Respect for persons: A curricular crisis in identities', in: Education, spirituality and the whole child, 125-126.

${ }^{424}$ P. Gordon \& J. White, Philosophers as educational reformers: The influence of idealism on British educational thought and practice, London 1979. See also Cuttingham, 'Spirituality, science and morality'.

425 See R. Prentice, 'The spirit of education: A model for the twenty-first century', in: Education, spirituality and the whole child, 313-339.

426 See J. Jacobs, 'Spirituality and virtue', in: Spirituality, philosophy and education, 55-66. See also The heart of learning: Spirituality and education (Ed. S. Glazer), New York 1999. 
this learning process is 'spiritual'? Can education be likened to a spiritual journey?427 This question about 'the intrinsic links between the two enterprises (education and spirituality, kw)' has been put by Colleen Griffith. ${ }^{428}$ The two enterprises have in common: they aim for fuller knowledge of the truth for the sake of life; they are committed to practices helping persons to orient their lives; they draw upon traditions, placing value on centuries-old experiences, and they foster inclusive thinking. They share common spiritual principles: engaging the depths of persons and welcoming the communal dimension. By way of practices of attentiveness, critical reflection and discernment a person's spiritual vitality is called forth. 'Such practices help to constitute more contemplative, deliberative, and socially conscious selves. When educators incorporate these practices intentionally into pedagogical processes, they advance the spiritual dimension of life'. ${ }^{429}$

Relationships. Modern educational theories were mostly aiming at the autonomously thinking and acting person. This aim was critisized for the first time by Martin Buber at the Third International Pedagogical Conference (1925) in Heidelberg. His proposal was: within an atmosphere of dialogue, educators lead the child toward personal and reciprocal participation in reality.

This dialogical spirituality has influenced, after World War II, educational theories. Romano Guardini, for instance, pleaded for a style of teaching which helps a person to listen to every situation, to distinguish and shape the values present in it. ${ }^{430}$ Dialogical pedagogy has been accorded wide reception, particularly in the area of spirituality and education. ${ }^{431}$ We present three recent examples. On the ground of their research, Hay and Nye concluded to their concept of 'relational consciousness' as the core of educational processes, both for research and teaching practice. ${ }^{432}$ Palmer aims at an educational setting, in which teachers create 'a space in which the community of truth is practiced', that is to say: truth as an ongoing conversation about things that matter, conducted with passion and discipline. ${ }^{433}$ Alexander situates educational processes in 'learning communities'

\footnotetext{
427 Palmer, To know as we are known.

428 C. Griffith, 'Education and spirituality', in: The new SCM dictionary of Christian spirituality, 266-267.

${ }^{429}$ Ibid., 266.

${ }^{430}$ R. Guardini \& O. Bollnow, Begegnung und Bildung: Weltbild und Erziehung, Würzburg 1956; see also F. Schulze, Begegnung und Unterricht, Nürnberg 1950; O. Bollnow, Existenz, Philosophie und Pädagogik, Stuttgart 1959.

431 See the chapter 'Pädagogik der Begegnung: Dialogische Motive in der modernen Erziehungswissenschaft', in: Schrey, Dialogisches Denken, 113-128.

${ }^{432}$ Hay \& Nye, The spirit of the child.

433 P. Palmer, The courage to teach: Exploring the inner landscape of a teacher's life, San Francisco 1998.
} 
devoted to a higher good, a communal framework in which genuine learning and teaching can happen and which calls for 'intelligent spirituality'. ${ }^{434}$ Reflecting on recent studies on spirituality and education, one may conclude that 'relationality' is becoming a more important concept in the relationship between teacher and student, in the learning community, in the relationship between school and environment (family, neighbourhood, society, and nature) and so forth. The question is whether the divine-human relationship will have its place in this field of relationships.

\section{WORKPLACE SPIRITUALITY}

In the field of spirituality, only since the 1930s some attention has been paid to spirituality and work. Famous is Chenu's Pour une théologie du travail (1955). Since Vatican II, the attention for this area is growing. ${ }^{435}$ But it is only in the last decades that from the realm of business and management itself a heightened attention for workplace spirituality can be observed. ${ }^{436}$ This growth has been explained from different perspectives: social and business changes causing turmoil, which spurs individuals to seek spiritual solutions to the consequent tensions; profound changes in values globally; and spiritual changes taking place in connection with growing interest in world spirituality. ${ }^{437}$

${ }^{434}$ H. Alexander, Reclaiming goodness: Education and the spiritual quest, Notre Dame 2001.

435 Gaudium et spes: Pastoral Constitution on the Church in the Modern World, Second Vatican Council Promulgated by His Holiness Pope Paul VI, December 7, 1965, http://www.vatican.va/archive/ hist_councils/ii_vatican_council/documents/vat-ii_cons_19651207_gaudium-et-spes_en.html, no.67; for an overview see P. Lamarche e.a. 'Travail', in: Dictionnaire de spiritualité, Paris 1991, vol. 15, 1186-1250; G. Mattai, 'Travailleur', in Dictionnaire de la vie spirituelle, Paris 1983, 1129-1143; E. Sellner, 'Work', in: The new dictionary of Catholic spirituality, Collegeville 1993, 1044-1051.

${ }^{436}$ E. Burack, 'Spirituality in the workplace', in: Journal of Organizational Change Management 12 (1999), 280-291; M. Fox, The reinvention of work: A new vision of livelihood for our time, San Francisco 1994; J. Edlund, Spiritualität und Management: Perspectiven unternehmerischen Fundamentalwandels, Wiesbaden 1998; D. Butts, 'Spirituality at work', in: Journal of Organizational Change Management 12 (1999) no.4, 328-331; G. Cavanaugh, 'Spirituality for managers: Content and critique', in: Journal of Organizational Change Management 12 (1999), 186-199; J. Sass, 'Characterizing organizational spirituality: An organizational communication culture approach', in: Communication Studies 51 (2000), 195-207; J. Neal, 'Spirituality in the workplace: An emerging phenomenon', in: Studies in Spirituality 15 (2005), 267-281.

437 Handbook of workplace spirituality and organizational performance, (Ed. R. Giacalone \& C. Jurkiewicz), New York - London 2003, 3-4; see I. Mitroff \& E. Denton, A spiritual audit of corporate America: A hard look at spirituality, religion, and values in the workplace, San Francisco 2002; E. Brandt, 'Corporate pioneers explore spirituality', in: HR Magazine April (1996), 82-87; L. Tischler, 'The growing interest in spirituality in business', in: Journal of Organizational Change Management 12 (1999), 273-279; F. Brandle, Ökonomie und Spiritualität: Verantwortliches Wirtschaften im Spiegel der Religionen, Hamburg 1997. 
Disciplines. Most studies in the new academic field of spirituality at work take a social scientific perspective (quantitative studies), discovering for example a high correlation between spiritual well-being and organizational openness, self-efficacy, and commitment, or other relevant correlations ${ }^{438}$. Groundbreaking in this area is the Handbook of Workplace Spirituality and Organizational Performance, ${ }^{439}$ a first attempt of systematic investigation into the role of spirituality in workplace performance, from a social scientific perspective. Critics ask however, whether these empirical studies are sufficient for the subject at hand, or even counterproductive. ${ }^{440}$ Moreover, the question is, whether a consensus construction based on a representative number of definitions may provide a useful 'concept', ${ }^{441}$ and whether the measurement tools are adequate. ${ }^{442}$

The study of workplace spirituality can be advanced by placing it in an interdisciplinary framework of social sciences and philosophy-theology. ${ }^{443}$ To bridge the gap between these two approaches, the construction of a 'sensitizing concept' for further qualitative exploration may be useful. ${ }^{444}$

Theories. The theoretical weakness of workplace spirituality is the split between a social scientific perspective and a philosophical-theological perspective. The two perspectives speak two languages. On the one hand, the social scientific scholars, being aware of the lack of a strong theoretical base, root their work explicitly in the existing empirical foundations: workplace spirituality has to be

438 D. Trott, Spiritual well-being of workers: An exploratory study of spirituality in the workplace, Austin 1996; H. Beazley, Meaning and measurement of spirituality in organizational settings: Development of a spirituality assessment scale, Washington 1997; D. Ashmos \& D. Duchon, 'Spirituality at work. A conceptualisation and measure', in: Journal of Management Inquiry 9 (2000) no.2, 134-145; K. Krahnke, R. Giacalone \& C. Jurkiewicz, 'Point - counterpoint: Measuring workplace spirituality', in: Journal of Organizational Change Management, 16 (2003) no.4, 396-405.

439 See note 437.

${ }^{440}$ P. Gibbons, 'Spirituality at work: Definitions, measures, assumptions and validity claims', in: Work and spirit: A reader of new spiritual paradigms for organizations (Eds. J. Biberman \& M. Whitty), Scranton (PA) 2000; C. Forniciari \& K. Lund Dean, 'Making the quantum leap: Lessons from physics on studying spirituality and religion in organizations', in: Journal of Organizational Change Management, 14 (2001) no.4, 335-351.

441 See, for instance Ashmos \& Duchon, 'Spirituality at work', 134-145.

442 See A. Altman, Worker satisfaction and economic performance, Armonk (NY) 2001; see also Handbook of workplace spirituality, 9-10.

${ }^{443}$ Groundbreaking in this respect is M. Benefiel, 'Strange bedfellows or natural partners? The academic study of spirituality and business', in: Studies in Spirituality 16 (2006), 273-285.

${ }^{4} 44$ See, for instance Mitroff \& Denton, A spiritual audit of corporate America; K. Lund Dean, C. Forniciari \& J. McGee, 'Research in spirituality, religion and work: Walking the line between relevance and legitimacy', in: Journal of Organizational Change Management 16 (2003) no.4, 378-395. 
integrated into the empirical research tradition. ${ }^{445}$ Looking for a valid concept, they separate clearly spirituality and religion. ${ }^{446}$ 'Workplace spirituality based on religion is ill-defined and untestable and therefore cannot contribute to a scientific body of knowledge'. ${ }^{447}$ Scholars of this tradition are inable to see any scientific contribution from the side of religion. But by doing so, they eliminate the most important schools of spirituality, which could offer a valid contribution on the level of 'sensitizing concepts', fundamental for every qualitative research. Moreover they close their eyes for the depth of the spiritual 'concepts' within the workplace itself. To give just one example: managers understand the field of spirituality as the presence of a supreme, transcendent force that defines purpose in human affairs; an acceptance that each person is linked to all the others in society, nature and the world; a sacredness and sense of awe toward all creation; and a source of inner peace, faith and willpower when facing difficult situations. ${ }^{448}$

On the other hand, from the philosophical-theological perspective no real interest in empirical research has been shown. Normally studies offer a broad and abstract approach: from the perspective of philosophy ${ }^{449}$ and religion in general, ${ }^{450}$ from Eastern ${ }^{451}$ and Western ${ }^{452}$ traditions, from New Age insights ${ }^{453}$ and modern worldviews. ${ }^{454}$

445 R. Giacalone \& C. Jurkiewicz, 'Toward a science of workplace spirituality', in: Handbook of workplace spirituality, 11-12; Sass, 'Characterizing organizational spirituality'; C. Cash, G. Gray $\&$ S. Rood, 'A framework for accommodating religion and spirituality in the workplace', in: Academy of Management 14 (2000), 124-134; J. Biberman \& M.Whitty, 'A postmodern spiritual future for work', in: Journal of Organizational Change Management 10 (1997), 130-138; L. Bolman \& T. Deal, Leading with soul: An uncommon journey of the spirit, San Francisco 1995; J. Scherer \& L. Shook, Work and the human spirit, Spokane 1993.

446 Giacalone \& Jurkiewicz, 'Toward a science of workplace spirituality', 5; 12-13; 17-21.

447 Ibid., 6.

448 Mitroff \& Denton, A spiritual audit of corporate America.

449 J. Heinrichs, Philosophische Überlegungen zur Spiritualität der Arbeit, Hennef 1989.

450 Work and religion (Ed. G. Baum), New York 1980.

$451 \mathrm{~J}$. Hawley, Reawakening the spirit at work: The power of dharmic management, San Francisco 1993; D. Koehn, 'What can Eastern philosophy teach us about business ethics?', in: Journal of Business Ethics 19 (1999) no.1, 71-80; L. Richmond, Arbeit und Spiritualität: Ein buddhister Weg zum inneren Wachstum und Zufriedenheit im Beruf, München 2000; J. Heider, The Tao of leadership: Lao Tsu's Tao te Ching adapted for a new age, Atlanta 1985.

$452 \mathrm{O}$. Williams \& J. Houck, The Judeo-Christian vision and the modern corporation, Notre Dame 1982; P. Pascarella, Christ centered leadership: Thriving in business by putting God in charge, Rocklin 1999; P. de Chauvigny de Blot, Vernieuwing van organisaties in een chaotische omgeving door vernieuwing van de mens: Een organisatievisie van Ignatius van Loyola, Breukelen 2004.

453 M. Nichols, 'Does New Age business have a message for managers?', in: Harvard Business Review 72 (1994) no.2, 52-61.

${ }^{454}$ Breng spirit in je werk (Ed. T. Hardjono \& H. Klamer), Zoetermeer 2005; J. Wessel Ganzevoort, Spiritualiteit in leiderschap: Een verkenning van de betekenis van spiritualiteit voor leiderschap in organisaties, Nijmegen 2003; P. de Chauvigny de Blot, Business spiritualiteit 
It is a challenge for the spirituality at work to develop a process of interdisciplinary exchange between the two mainstream approaches. Mediating ideas are needed, for instance the methodology of Lonergan ${ }^{455}$ or the idea of 'sensitizing concepts' developed in the grounded theory and in qualitative research strategies.

Professions. Sometimes, workplace spirituality is conceived in a rather broad and abstract sense as a system of interwoven cultural and personal changes, penetrating all aspects of life, including organizational life. ${ }^{456}$ In fact, the personal and organizational levels are more directly interrelated. ${ }^{457}$ Therefore the science of workplace spirituality is mostly focused on identifying the practical implications of this kind of spirituality, its utility in an economic context, the impact of spiritual variables on work-related processes.

Roughly speaking, one may distinguish five models for fostering spirituality on the workplace: religious based firms, guided by (mostly) Christian principles; evolutionary firms, lead by a mixture of religious and philosophical convictions, mostly expressed in a 'spiritual' business code (including values, strategies, product quality, human potentials, environment); recovering organizations, following 12-step programs; the socially responsible firm, where soul and spirituality are explicitly embraced as core business principles; the values based company, favouring non-religious and non-spiritual secular values. ${ }^{458}$

Mostly the attention is focussed on the role of the leader or the manager, 459 although the perspective of the worker is not completely absent. ${ }^{460}$ Attempts are made to give an overview of insights and developments. ${ }^{461}$

als kracht voor organisatievernieuwing: Op zoek naar de mystiek van het zakendoen, Eemnes 2006; Spiritualiteit in managen en besturen, een vruchtbare verbinding? (Ed. H. Klamer \& H. Pieper), Budel 2003.

455 See again Benefiel, 'Strange bedfellows or natural partners?'; see also D. Helminiak, The human core of spirituality, Albany 1996.

456 B. Zinnhaver e.a., 'The emerging meanings of religiousness and spirituality', in: Journal of Personality 67 (1999), 889-919.

457 Sass, 'Characterizing organizational spirituality'.

458 See Mitroff \& Denton, A spiritual audit of corporate America.

459 Cavanaugh, 'Spirituality for managers; H. Bracey et al., Managing from the heart, New York 1990; M. Benefiel, Soul at work: Spiritual leadership in organizations, New York 2005; L. Fry, 'Toward a theory of spiritual leadership', in: Leadership Quarterly 14 (2003), 693-727; J. Conger et al., Spirit at work: Discovering the spirituality in leadership, Oxford 1994; Leading with wisdom: Spiritual-based leadership in business (Ed. P. Pruzan \& K. Pruzan Mikkelsen), Sheffield 2007.

${ }^{460}$ R. Matter, The Christian employee, South Plainfield 1978; J. Milliman, A. Czaplewski \& J. Ferguson, 'Workplace spirituality and employee work attitudes: An exploratory assessment', in: Journal of Organizational Change Management 16 (2003), 426-447.

461 Work and spirit (Eds Biberman \& White). 
Words. Looking at more than 300 titles of the selected bibliography Spirit at Work ${ }^{462}$ one may discover an almost complete vocabulary of workplace spirituality: words regarding the broader context (world, global, culture, economy, religions, society, capitalism, marketplace, money, etc.), the concrete reality at stake (work, organization, business, profit, job, career, workplace, company, consultant, guide etc.), roles (leader, manager, employee, worker, etc), values (love, dignity, respect, truth, honesty, trust, etc.), spiritual attitudes (creation, vision, intuition, passion, soul, spirit, service, etc.), and processes (transformation, learning community, journey, growth, etc.). It is remarkable how many 'soft' words occur in the field of workplace spirituality. ${ }^{463}$

Things. Although a prima vista the workplace itself seems to be the very incarnation of things and the production of things, no studies in the field of spirituality at work are available taking their point of departure in precisely this material dimension. Probably, the 'material culture' of work does not fit in the theoretical framework of the researchers. In the above mentioned Handbook of Workplace Spirituality and Organizational Performance, no study can be found starting from the perspective of things and material culture, as silent expression of incarnated spirituality. On the other hand, the Handbook of Material Culture 464 contains not a single section or article concerning work and workplace.

Images. In workplace spirituality, the world of work and the world of images, art and symbolism are connected on three levels.

The first level is more general and in itself 'symbolic'. Studies use art metaphors, speaking about the spirituality of work and organizations. ${ }^{465}$ Images from the world of art and symbols are used as models of interpretation, challenging the spirit at work.

The second level is more concrete. One of the entrances to introduce spirituality seems to be creativity. The idea is that the normal attitude of reproduction - without soul and spirit - should be transformed into the direction of creativity.

\footnotetext{
462 http://www.spiritatwork.org/research/biblio-books-A-K.htm and http://www.spiritatwork.org/ research/biblio-books-L-Z.htm.

463 To give just a few examples: J. Autry, Love and profit: The art of caring leadership, New York 1991; R. Barrett, Liberating the corporate soul, Boston 1998; E. Dale, Bringing heaven down to earth: A practical spirituality of work, New York 1999; C. Osborn, Inner excellence: Spiritual principles of life-driven business, New York 1992; Rediscovering the soul in business: A renaissance of values (Ed. B. Defoore \& J. Renesch), San Francisco 1995.

464 Handbook of material culture (Ed. C. Tilley e.a), London 2006.

465 To give some examples: N. Atthreya, Spiritual culture in the cooperate drama, Mysore 1997; P. Barrentina, When the canary stops singing: Womens's perspectives on transforming business, San Francisco 1993; R. Harrison, Consultant's journey: A dance of work and spirit, San Francisco 1995.
} 
Management, for instance is understood as art. ${ }^{466}$ But also for the organization as such, art and creativity are leading principles, particularly the items of imagination and learning. ${ }^{467}$ Sometimes these insights are linked with creativity psychology ${ }^{468}$ and chaos theory. ${ }^{469}$

The third level creates a more direct connection between art and organization. Zander shows how he learned, as a conductor, to give more space for personal responsibility and creativity to the members of his orchestra, and how the performance improved. ${ }^{470}$ In this way, an artistic work provides a concrete model of leadership. ${ }^{471}$ Sometimes an artistic view from within the workplace has been given. ${ }^{472}$

Texts. As we have seen, most studies on workplace spirituality take a social scientific perspective and are almost exclusively oriented on the practices of management and business. In this approach, a textual dimension is practically excluded. No corpus of texts is present in the memory of researchers. An exception is the Bible as a reference work for those who try to bring spirituality into the workplace from a Christian background. 473 Sometimes, texts of spiritual traditions are in a more general way adapted to the modern workplace and leadership. ${ }^{474}$

Histories. Although workplace spirituality mostly has an a-historical attitude, there is some interest in recent history: the paradigm shift from Modernity to

466 Autry, Love and profit; M. de Pree, Leadership as an art, New York 1989; A. Low, Zen and creative management, Tokyo 1976; P. Vaill, Managing as a performing art, San Francisco 1989; J. Walters, The art of supportive leadership, Nevada City 1987.

467 A. Diaz, Freeing the creative spirit, San Francisco 1992; M. Giovagnoli, Angels in the workplace: Stories and strategies for creating a new world of work, San Francisco 1998; J. Holland, Creative communion, New York 1989; L. Jones, The path: Creating your mission statement for work and for life, New York 1996; P. Palmer, The active life: Wisdom for work, creativity and caring, New York 1990; M. Ray \& R. Myers, Creativity and business, New York 1986; P. Senge, The fifth discipline: The art and practice of the learning organization, New York 1998.

468 R. May, The courage to create, New York 1975; M. Czikszentmihalyi, Finding flow: The psychology of engagement with every day life, New York 1997.

${ }^{469}$ M. Youngblood, Life at the edge of chaos: Creating the quantum organization, Dallas 1997.

${ }^{470}$ R. Zander \& B. Zander, The art of possibility, Cambridge 2000.

${ }^{471}$ J. Cameron, The artist's way: A spiritual path to higher creativity, New York 1992; Id., The artist's way at work, New York 1998.

472 R. Windle, The poetry of business life: An anthology, San Francisco 1994.

473 J. Bernbaum \& S. Steer, Why work? Careers and employment in biblical perspective, Grand Rapids 1986; B. Briner, The management methods of Jesus, Nashville 1996; L. Burkett, Business by the book: The complete guide of biblical principles for business man and woman, Nashville 1990.

${ }^{474}$ See, for instance, W. Derkse, Een leefregel voor beginners: Benedictijnse spiritualiteit voor het dagelijks leven, Tielt 200514; A. Grün, Leben und Beruf-Eine spirituelle Herausforderung, Münsterschwarzach 2005; Chauvigny de Blot, Vernieuwing van organisaties in een chaotische omgeving door vernieuwing van de mens; Compassie: Ondernemers over mededogen (Ed. B. Rutgers van der Loeff e.a.), Zoetermeer 2004. 
Postmodernity. The common opinion is that the capability to give meaning to work has been diminished by Modernity in as far as this modern worldview has caused a general loss of meaning, a process of functional differentiation and the dominance of instrumental rationality. ${ }^{475}$ Both nationally and internationally, value changes emerge, reflecting a comprehensive shift in spirituality, of course influencing business and management. ${ }^{476}$

Some signs of these historical changes are: propensity to favour post-materialist social values, such as social equality, participation, freedom, concern for quality-of-life etc. over more materialist ones; 477 the emergence of 'cultural creatives', tending to be more idealistic, spiritual, socially conscious, and desiring to create a future for all $;{ }^{478}$ the tendency in the broad academy to stop further fragmentation and to discover more integrative and collaborative systems, focussing on interconnectedness and qualitative aspects of phenomena. ${ }^{479}$

Processes. Basically, the option for workplace spirituality is a reinvention of the capacity to reinterpret the world of work. This means that a processual approach of work challenges the workers to break open the closed circles of interpretation, to liberate themselves from the narrow horizon of one-dimensional economic rationality and cliché interpretations of the world. ${ }^{480}$

Some scholars try to integrate spirituality in the workplace by establishing of a value system, which enables the human spirit to grow. Mentioned values or virtues are: trust, truth, justice, honesty, freedom, courage, wisdom, compassion. ${ }^{481}$

Other scholars emphasize human developments, maximizing human capital, encouraging employees to participate in human potential programs and improving the personal contribution. Spirituality can enhance intuitive abilities, increase

475 T. Pauchant, La quête du sens: Gérer nos organisations pour la santé des personnes, de nos sociétés et de la nature, Montreal 1996; C. Handy, The hungry spirit: Beyond capitalism: A quest for purpose in the modern world, New York 1998.

476 The new paradigm in business (Ed. M. Ray \& A. Rinzler), New York 1993; R. Giacalone \& D. Eylon, 'The development of new paradigm values, thinkers and business', in: American Behavioral Scientist 43 (2000), 1217-1230.

477 R. Inglehart, Culture shift in advanced industrial society, Princeton 1990.

478 P. Ray, The integral culture survey: A study of transformational values in America, Sausalito (CA) 1996.

479 Giacalone \& Eylon, 'The development of new paradigm values, thinkers and business'.

${ }^{480} \mathrm{~J}$. Verstraeten, 'Dépasser la morale sectorielle: La contribution d'une étique hermeneutique et théologique', in: Revue d'étique et de théologie morale 213 (2000), 83-104; Fox, The reinvention of work; Conger, Spirit at work; G. Hendricks, Visionäres Management als Führungskonzept der Zukunft: Wirtschaflicher Erfolg durch Integrität, Intuition und Spiritualität, München 1997.

${ }^{481}$ Autry, Love and profit; Barrett, Liberating the corporate soul; K. Balanchard \& M. O'Connor, Managing by values, Dehli 1991; R. Dass \& M. Bush, Compassion in action, New York 1992; J. Della Costa, Working wisdom: The ultimate value in the new economy, Toronto 1995; Rediscovering the soul in business (Ed. Defoore \& Renesch). 
innovation and creativity, improve teamwork and employee commitment, facilitate a more powerful vision, connectedness in relationships. ${ }^{482}$ In this area we observe a very frequent use of 'spirit' and 'soul'. ${ }^{483}$

A third line is looking for mediations between values and the human potential. Scholars speak about a way, a journey, a process of transformation and discernment, about strategies and exercises, about a learning community providing a fertile place for creativity, energy and motivation. ${ }^{484}$ Precisely, the ongoing process of transformation between values and the human subject is a sign of spirituality. ${ }^{485}$

An important question is, whether workplace spirituality is institutionally embedded in a framework of organizational values, facilitating employees' experience of transcendence through the work process. ${ }^{486}$

Relationships. Five factors seem to mark the spiritual calibre of a business enterprise: a sound business code, attention to product quality, attention for community, the social outlook of the business, and respect for the environment. Three of these factors are referring to relationship and connectedness. ${ }^{487}$

Firstly, the question is whether a company cuts itself off from or makes a contribution to the common interest. The consciousness to live in a global world is essential for a sound workplace spirituality. 488 This includes solidarity with oppressed colleagues in poor countries, resistance against dictatorial regimes, protest against child labour, and so forth. Basically, a spiritual attitude is needed: choosing service over self-interest. ${ }^{489}$

Secondly, the global world is embedded in nature and environment. Everyone knows that human business has deteriorated the ecosphere: monocultures,

482 See, for instance, C. Neck \& J. Milliman, 'Thought self-leadership: Finding spiritual fulfilment in organizational life', in: Journal of Managerial Psychology 9 (1994), 9-16; Trott, Spiritual wellbeing of workers; R. McKnight, 'Spirituality in the workplace', in: Transforming work (Ed. J. Adams), Alexandria (VA) 1984, 138-153.

483 To give just a few examples: L. Berry, Discovering the soul of service: The nine drivers of sustainable business success, New York 1999; D. Block \& L. Richmond, Soul work: Finding the work you love, loving the work you have, Palo Alto 1998; Bolman \& Deal, Leading with soul; A. Briskin, The stirring of the soul in the workplace, San Francisco 1996; T. Chappell, The soul of a business, New York 1993; Conger, Spirit at work.

${ }^{484}$ Transforming leadership: From vision to results (Ed. J. Adams), Alexandria 1986; A. Arrien, The fourfold way: Walking the paths of the warrior, teacher, healer and visionary, San Francisco 1993;

L. Bolman \& T. Deal, Reframing organizations, San Francisco 1997.

${ }^{485}$ K. Waaijman, 'Bedrijfsspiritualiteit: Naar een lerende gemeenschap', in: Spiritualiteit in managen en besturen, 17-30.

486 Giacalone \& Jurkiewicz, 'Toward a science of workplace spirituality', 14.

487 E. Guba, The paradigm dialog, Newbury Park (CA) 1990.

488 P. Abramson \& R. Inglehart, Value change in global perspective, Ann Arbor 1995.

${ }^{489}$ P. Block, Stewardship: Choosing service over self-interest, San Francisco 1993. 
soil erosion, pollution, bio-industries, chemical waste, oil spills, radio-active materials, and excessive use of energy. Responsibility for the quality of the environment and for the sustainability of the earth is essential for an authentic workplace spirituality. 490

Thirdly, connectedness takes shape in the development of relationship in the organisation. Workers have a sense of community, contribute to the betterment of the other, go beyond their self-interests. ${ }^{491}$ Some organisations try to understand themselves as a learning community, in which trainings are offered improving processes of creativity, respect, energy, and motivation. ${ }^{492}$ Initiatives are undertaken by organisations that are designed to be supportive toward families. ${ }^{493}$

\section{SPIRITUALITY AND MEDICINE}

In the last decades, physicians, nurses, and other health care professionals explored the spiritual aspects of care. They reflected the theoretical implications of the interdisciplinarity of spirituality and health care. The effects of spirituality on patients are empirically investigated. Efforts are made to incorporate spirituality into practice. Courses of spirituality and health are becoming common in medical and nursing schools. It is evident that the role of spirituality in this field of human experience is recognized. ${ }^{494}$

490 G. Cohen, 'Toward a spirituality based on justice and ecology', in: Social Policy (Spring 1996), 16-18; P. Hawken, The ecology of commerce, New York 1994.

${ }^{491}$ D. Bakan, The duality of human existence: An essay on psychology and religion, Chicago 1996; V. Helgeson, 'Relation of agency and communion to well-being: Evidence and potential explanations', in: Psychological Bulletin 116 (1994), 412-428.

492 P. Senge, The fifth discipline fieldbook: Strategies and tools for building a learning organization, New York 1994; Community building: Renewing spirit and learning in business (Ed. K. Gozdz), San Francisco 1995; Learning organizations: Developing cultures for tomorrow's workplace, San Francisco 1995.

493 J. Glass \& S. Estes, 'The family responsive workplace', in: Annual Review of Sociology 23 (1997), 289-313; R. Kanter, Work and family in the United States: A critical review and agenda for research and policy, New York 1977; I. Wolcott, A nice place to work: Small business and workers with family responsibilities, Melbourne 1996.

${ }^{494}$ H. Koenig, Spirituality in patient care: Why, how, when and what, Philadelphia-London 2002; L. Tiesinga, R. Driebergen e.a., 'Het spiritueel functioneren van patiënten en verpleegkundigen: Een essentiële dimensie in de gezondheidszorg', in: Tijdschrift voor Gezondheidszorg \& Ethiek 13 (2003) no.4, 103-107; M. Prins, Geestelijke zorgverlening in het ziekenhuis, Dwingeloo 1996; L. Tiesinga, R. Driebergen e.a., 'Spiritualiteit en verplegen: Een literatuurstudie naar de plaats van spiritualiteit binnen het verpleegkundig kennis- en beroepsdomein', in: Verpleegkunde 18 (2003), 159-168; Nursing and spiritual care (Eds. O. McGilloway \& F. Myco), London 1985; M. Cobb \& V. Robshaw, The spiritual challenges of health care, London 1998; J. Collins, Spirituality for the $21^{\text {st }}$ century, Dublin 1999; E. Farmer, Exploring the spiritual dimension of care, Lancaster 1996; M. Roach, Caring from the heart: The convergence of caring and spirituality, New York 1997; 
Disciplines. Particularly in the USA, the interdisciplinarity in the field of spirituality and health care is flourishing. We observe a growth of research and education in the Medicine Faculties of the USA. Circa 80 faculties offer courses in spirituality and health care. Important is the George Washington Institute for Spirituality and Health, directed by Christiana Puchalski.

There is an amount of empirical research on the effects of 'spirituality on health'. On behalf of this evidence based research, researchers are strongly occupied by conceptualisation. ${ }^{495}$

Within psychiatric assessment and treatment the Handbook of Spirituality and Worldview in Clinical Practice is groundbreaking. ${ }^{496}$ Although focussing primarily on the cognitive aspects of belief, the concepts of spirituality and health care are clear and a lot of attention has been paid to the patients and their traditions (six chapters). More important for the whole field of spirituality and health care is The Rebirth of the Clinic, ${ }^{497}$ an introduction to the spirituality in health care, examining its meanings, values and foundations, including its educational and practical implications. Sulmasy builds a scholarly foundation for spirituality as the essential element for good health practice, integrating spirituality without abandoning centuries of science. ${ }^{498}$

Theories. The scientific, anatomical-pathological approach to medicine that emerged between the Enlightenment and the establishment of university clinics in the nineteenth century, dominated the scientific foundations and empirical successes of Western medicine. Roughly speaking, one may observe three major theoretical frameworks in the field of spirituality and health care.

S. Ronaldson, Spirituality: The heart of nursing, Melbourne 1997; D. Stoter, Spiritual aspects of health care, London 1995. For a list of internet sites and online resources see: M. Stevermer, 'Spirituality and health care: Internet sources', in: Medical Reference Service Quarterly 23 (2004) no.2, 57-71.

495 M. Burckhardt, 'Spirituality: An analysis of the concept', in: Holistic Nurse Practioner 3 (1989) no.3, 69-77; C. Hermann, Spiritual needs of dying patients: A methodological study, Kentucky 1997; D. Allen, Coverage of the spiritual dimension of health in personal health textbooks in higher education, Denton-Dallas-Houston 1993; L. Hood Morris, The concept of spirituality in the context of the discipline of nursing, Vancouver 1995; B. Cusveller, R. van Leeuwen e.a., 'Whose care, which spirituality?' in: Verpleegkunde 17 (2002), 232-233; E.E. Labun, 'Spiritual care: An element in nursing', in: Journal of Advanced Nursing 13 (1988), 314-320; B.S. Barnum, Spirituality in nursing: From traditional to New Age, New York 1996.

496 Handbook of spirituality and worldview in clinical practice (Ed. A. Josephson \& J. Peteet), Arlington 2004.

497 D. Sulmasy, The rebirth of the clinic: An introduction to spirituality in health care, Washington 2006.

${ }^{498}$ D. Eisenberg, R. Kessler e.a., 'Perceptions about complementary therapies relative to conventional therapies among adults who use both: Results from a national survey', in: Annals of Internal Medicine 135 (2001), 344-351. 
Firstly, attemps to integrate traditional spiritualities and health care: Jewish insights, ${ }^{499}$ Christian visions, ${ }^{500}$ and other traditions. The integration of these traditions within health care is mostly fuelled by basic values, such as compassion, or other sources. ${ }^{501}$

Secondly, holistic approaches, integrating somatic, psychological, social and spiritual dimensions in health care. ${ }^{502}$ The spiritual dimension is mostly conceived as a rather broad concept: illness and suffering provoke fundamental existential questions about life and death, both in patients and caregivers. Nursing practice has to consider patient's 'spiritual needs' in order to provide total patient care. ${ }^{503}$

Thirdly, the alternative circuit criticizes basically modern Western health care. Here, we observe a rainbow of visions from indigenous spiritualities, New Age ideas, and so on..$^{504}$

499 J. Op 't Root, 'Als je leven zoekt': Gezondheid en genezen in anthropologisch perspectief: Joodse traditie als levensoriëntatie, Maastricht 1984 (Dissertation).

500 A. Bradshaw, Lighting the lamp: The spiritual dimension of nursing care, Harrow 1995; V. Benner-Carson, Spiritual dimensions of nursing practice, Philadelphia etc. 1989; S. Cassidy, Sharing the darkness: The spirituality of caring, London 1990; S. Dybowski, Barmherzigkeit im Neuen Testament: Ein Grundmotiv caritativen Handelns, Freiburg 1992; H. Finney, A spirituality of compassion: Studies in Luke, Elgin (IL) 1996; G. Prové, Becoming human: A story of transformation through conflict and healing, Delft 2004.

501 K. Waaijman, 'Barmhartigheid: De ziel van de zorg', in: Het ziekenhuis als morele gemeenschap (Ed. M. Pijnenburg \& M. Nuy), Budel 2003, 89-96; Hoop als helpende hand: Een medische verkenning met filosofische en pastorale kanttekeningen (Ed. V. Kirkels \& H. Rouwenhorst), Nijmegen 2003 (Annalen van Thijmgenootschap 91, afl. 2); H. Benson, Timeless healing: The power and biology of belief, New York 1996; H. Koenig, Aging and God: Spiritual pathways to mental health in midlife and later years, New York 1994; D. Langford, Where is God in all of this? A study of spiritual care of terminally ill, Southampton 1989; J. Shelly \& A. Miller, Called to care: A Christian theology of nursing, Downers Grove (IL) 1999; M. O’Brien, Spirituality in nursing: Standing on holy ground, Boston 1999.

502 L. Flanelly, K. Flanelly \& A. Weaver, 'Religious and spiritual variables in three major oncology nursing journals: 1990-1999', in: Oncology Nursing Forum 29 (2002), 679-685; E. Johnston Taylor, 'What have we learned from spiritual care reseach?' in: Journal of Christian Nursing 22 (2005), 22-29; G. Fitchett, Assessing spiritual needs: A guide for caregivers, Minneapolis 1993; B. Cusveller, 'Zorg met een hoofdletter: Een wijsgerig-anthropologische verantwoording van spiritualiteit in de verpleegkundige zorgverlening', in: Tijdschrift voor Gezondheidszorg \& Ethiek 13 (2003) no.3, 81-84; D. Sipsma, 'Zorg en spiritualiteit', in: Verpleegkunde 17 (2002), 121; C. Taylor, C. Lillis e.a., Fundamentals of nursing: The art and science of nursing care, Philadelphia 1989; D. Hodges, Science, spirituality and healing, Guilford 1994; Spirituality in nursing: A new perspective in health, Milwaukee 1984; H. Jochemsen e.a., Levensvragen in de stervensfase: Kwaliteit van spirituele zorg in de terminale palliatieve zorg vanuit patiëntenperspectief, Ede 2002.

${ }^{503}$ I. Govier, 'Spiritual care in nursing: A systematic approach', in: Nursing Standard 14 (2000) no.17, 32-36; J. Chibnall e.a., 'Psychosocial-spiritual correlates of death distress in patients with life-threatening medical conditions', in: Palliative Medicine 16 (2002) 331-338; B. Mount, 'Healing and palliative care: Charting our way forward', in: Palliative Medicine 17 (2003) 657-658.

504 Barnum, Spirituality in nursing. 
Professions. By far, the biggest part of research and scholarly efforts is spent on spirituality related to the profession of health care. The so-called clinical practice is complex and encompassing several perspectives and interests.

First of all, nursing practice encompasses different elements: the nursing competency with its domains (self-awareness and communication, spiritual aspects in the nursing process, quality assurance, expertise development, intervision etc.). 505

Health care technology and science have witnessed incredible advances for physical and psychological disorders, but the spiritual dimension of care is an intervention resource often gone unseen, unaddressed and underused for patients, such as: diagnosis and anamnesis, ${ }^{506}$ data collection of spiritual dysfunctioning of the patient, including specific dimensions (faith, meaning, vocation, experience, emotion, courage, growth, rituals, community, direction); 507 presence, listening and empathy; 508 interdisciplinary cooperation, including recognition of different roles. 509

Within the nursing profession, a focus on patients as bio-psycho-social-spiritual beings is gaining recognition. However, at the same time there is evidence

${ }^{505}$ R. van Leeuwen \& B. Cusveller, 'Naar een verpleegkundig competentieprofiel voor de zorg voor spiritualiteit', in: Verpleegkunde 18 (2003) no.2, 72-81; A. Eliëns \& C. Frederiks, 'Spirituele problemen in de verpleegkunde: Religie en zingeving bij patiënten', in: Verpleegkundige probleemgebieden: Diagnoses \& interventies (Ed. T. van Achterberg), Dwingeloo 1998; L. Ross, 'Spiritual aspects of nursing', in: Journal of Advanced Nursing 19 (1994) no. 3, 439-447; R. van Leeuwen, L. Tiesinga e.a., 'De samenhang tussen spiritualiteit en gezondheid bij patiënten met lichamelijke aandoeningen: Een analyse van geneeskundige en verpleegkundige studies', in: Tijdschrift voor gezondheidswetenschappen 82 (2004), 307-316; R. van Leeuwen \& B. Cusveller, Verpleegkundig competentieprofiel: Zorg voor spiritualiteit: Een verkennende literatuurstudie, Ede 2002; J. Harrison \& Ph. Burnard, Spirituality and nursing practice, Aldershot e.a. 1993.

${ }^{506}$ M. Gordon, Handleiding verpleegkundige diagnostiek 1997-1998, Utrecht 1997; L. Carpenito, Nursing diagnosis: Application to clinical practice, Philadelphia 1993; R. van Leeuwen, G. Hunink, 'Spiritual sistress: een verpleegkundige diagnose?', in: Verpleegkunde 15 (2000) no.1, 41-49.

507 W. Smeets, 'De spirituele component van zorg', in: Verpleegkunde 17 (2002) no.4, 234-240; A. Fulton, 'The spiritual variable, essential to the client system', in: The Newman systems model (Ed. B. Newman), Norwalk 1995; R. Morrison, 'Spiritual health care and the nurse', in: Nursing Standard 4 (1989), 28-29; Nieuw handboek geestelijke verzorging (Ed. J. Dolaard), Kampen 2006.

508 See for instance Benner-Carson, Spiritual dimensions of nursing practice, 164-175.

${ }^{509}$ Flanelly, Flanelly \& Weaver, 'Religious and spiritual variables in three major oncology nursing journals (1990-1999)'; A. Naranyasamy, 'A critical incident: Study of nurses' responses to the spiritual needs of their patients', in: Journal of Advanced Nursing 33 (2001), 446-455; W. Smeets, Spiritual care in a hospital setting: An emperical-theological exploration, Nijmegen 2006; R. van Leeuwen, L. Tiesinga, D. Post \& H. Jochemsen, 'Spiritual care: Implications for nurses' professional responsibility', in: Journal of Clinical Nursing 15 (2006), 875-884. 
that many nurses are not familiar with the spiritual dimension of human beings. ${ }^{510}$ Little or no effects are made to develop medical curricula in which courses in spirituality and health are taught alongside anatomy and physiology. ${ }^{511}$

In the past century, the nursing profession detached itself from the all-embracing motivation of calling. It started to organize itself as a profession on itself, required a recognized and contractually enforced status. We saw an increase of expertise, protected certification, and professional codes. But after a century the need is felt for an open, spiritual model, driven by an open orientation ${ }^{512}$ and supported by inspiring central motives like inner space, soul, justice, forgiveness, and other leading ideas. ${ }^{513}$

The practice of spirituality and nursing is embedded in a triangle of perspectives and interests: the patient, the caregiver, and the institutional setting. This last element deserves more scholarly reflection. The institutional setting is important for the safeguarding of the value system and the level of competencies. ${ }^{514}$

Words. The semantic field of spirituality and health care is a rich one. Not only the more technical terms are important: illness, sickness, care, cure, healing, health nursing, patient, caregiver, diagnosis, anamnesis, etc. Also, the more spiritual words deserve research: mercy, compassion, vulnerability, existential need,

510 W. Greenstreet, 'Teaching spirituality in nursing: A literature review', in: Nurse Education Today 19 (1999) no.8, 649-658; W. McSherry, Making sense of spirituality in nursing practice: An interactive approach, London 2000.

511 J. Price, 'Spiritual caregiving in nursing practice', in: Journal of Psychosocial Nursing 12 (1995), 5-9; W. McSherry \& P. Draper, 'The spiritual dimension: Why the absence within nursing curricula?' in: Nurse Education Today 19 (1999), 274-285.

512 R. van Leeuwen \& B. Cusveller, 'Nursing competencies for spiritual care', in: Journal of Advanced Nursing 48 (2004), 234-246; Fitchett, Assessing spiritual needs.

513 C. Leget, Ruimte om te sterven: Een weg voor zieken, naasten en zorgverleners, Tielt 20032; H. de Dijn, De herontdekking van de ziel: Voor een volwaardige kwaliteitszorg, Nijmegen 1999 (Annalen van het Thijmgenootschap 87, afl.3); Waaijman, 'Barmhartigheid: De ziel van de zorg'; C. Clark, J. Cross et al., 'Spirituality: Integral to quality care', in: Holistic Nursing Practice 5 (1991), 67-76; Forgiveness: Theory, research and practice (Ed. Michael E. McCullough, Kenneth I. Pargament, Carl E. Thoresen), New York 2000; S. Wright \& J. Sayre-Adams, Sacred space: Right relationship and spirituality in healthcare, Edinburgh 2000; K. Waaijman, 'Spiritualiteit in de zorg: In de interactie tussen zorgvrager en zorgverlener', in: Spiritualiteit en zingeving in de gezondheidszorg (Ed. J. Bouwer), Kampen 2004, 19-41; V.A. Sharpe, 'Justice and care', in: Theoretical Medicine 13 (1992), 295-318.

${ }^{514}$ F. Gribnau \& M. Pijnenburg, 'Spiritualiteit en zingeving in de zorg', in: Spiritualiteit en zingeving in de gezondheidszorg, 81-100; D. Bakker, 'Spiritualiteit in zorgvisie en beleid', in: Ibid., 42-58; K. Waaijman, 'Wat is spiritualiteit en hoe doet zij zich voor in de gezondheidszorg?' in: Zinervaring in de zorg (Ed. J. Jochemsen \& E. van Leeuwen), Assen 2005, 21-36; see also: Was ist Krankheit? Erscheinung, Erklärung, Sinngebung (Hrsg. K. Rotschuh), Darmstadt 1975. 
soul, spirit etc. For traditional texts some research has been done. ${ }^{515}$ But in semantic research from a modern perspective, almost no research has been performed. 516

Things. The advances for physical and psychological disorder are strongly propelled by concentration on the biological and anatomical aspects of illness. By stressing the so-called 'spiritual dimension', the unreflected presupposition could be that the 'spiritual' is completely different from such 'material' aspects as institution, management, pharmacy, body, and so on. This is, however, a presupposition which has been criticized for decades in the discipline of spirituality.

Images. In lived spirituality there is connaturality between art and healing processes. In all spiritualities, images are credited with healing and miracle working power. In indigenous spiritualities, the rhythms and melodies of ritual music influence deeply the body (heart, breath, movement, and gestures) and the soul (emotions and awareness) of the practioners and are used in healing practices. From the perspective of modern medicines, there is no relation between spiritual art and medicinal practices, except perhaps some elements in music therapy and in some alternative medicines. ${ }^{517}$ But in these cases, the factor of spirituality is marginal.

Texts. Apart from some traditional text, such as the statement of Jesus Sirach ${ }^{518}$ and the Psalms for illness and healing ${ }^{519}$ no serious edition of important texts in the field of spirituality and healthcare can be mentioned. Consequently no commentary has been written.

Histories. The historical dimension of spirituality is important. It provides a basics for a critical evaluation of Western medicines. Such a critical study is Michel Foucault's The Birth of the Clinic. ${ }^{520}$ His position provoked discussions, ${ }^{521}$ particularly the polemical response of Daniel Sulmasy's The Rebirth of the Clinic.

515 K. Waaijman, 'Gunst en vertedering: Barmhartigheid in het Oude Testament', in: Speling 51 (1999) no.1, 52-59; K. Seybold \& V. Müller, Krankheit und Heilung, Stuttgart 1978; K. Seybold, Das Gebet des Kranken im Alten Testament: Untersuchungen zur Bestimmung und Zuordnung der Krankheits- und Heilungspsalmen, Stuttgart 1973.

516 W. Reich, 'The history of the notion of care', in: Encyclopedia of bioethics (Ed. W. Reich), New York 1995², 319-331; see also Waaijman, 'Barmhartigheid: De ziel van de zorg', 93-94.

517 D. Aldridge, Health, the individual and integrated medicine: Revisiting an aesthetic of health care, London-New York 2004.

518 See Sulmasy, The rebirth of the clinic, 4.

${ }^{519}$ K. Waaijman, Psalmen bij ziekte en genezing, Kampen 1981.

${ }^{520}$ M. Foucault, The birth of the clinic: An archeology of medical perception, New York 1994.

${ }^{521}$ See I. Illich, Medical nemesis: The expropriation of health, New York 1976. 
Foucault describes the emergence of scientific, pathological medicines in the Enlightenment period. With its scientific-empirical approach the clinic became medicine's living laboratory. Medicine deeply transformed into 'a practice of power, a form of control, a scientific discourse, a form of applied engineering'. 522 It needs an evaluation of the history of spirituality and health care in the Western culture, encompassing the roots of biblical and Hellenistic spiritualities.

Processes. In pre-modern times sickness, healing, and health were part of a spiritual process, including family and neighbours. In the book of Psalms and Laments we may observe these spiritual processes. ${ }^{523}$ In the healing process mercy and compassion were important virtues (being a giving love), spontaneously welling up in the heart and streaming out in abundance, and a tender-heartedness, touched by the sight of the other. ${ }^{524}$ Classical Christian elements were service and dedication, facilitating the healing process. ${ }^{525}$

In modern times, the interactive process of secularization, emancipation, and professionalization has oppressed the spirituality of health care. In the medical-biological process which is strongly fragmentized, the deeper motivation of the caretakers, which is inherent in the care of the sick, and the spiritual processes of the sick, are lost sight of.

It is understandable that from within, the field of health care people looked for ways to escape this impoverishment. Models are in development to reintegrate the spiritual dimension, encompassing processual elements as faith, vocation, experience etc. One of these elements is growth and the courage to cope with illness and crisis. 526

Relationships. Connectedness and relation are important categories in the field of health care spirituality, over against the tendency in modern medicine to isolate and objectify the patient.

Firstly, over against the modern medical attitude to isolate the somatic and psychological dimension of the patients, health care spirituality intergrates the psycho-somatic, the social and the spiritual dimension of the caretakers. Moreover, from the perspective of spirituality, the psycho-somatic and social dimension belongs essentially to the spiritual.

522 Sulmasy, The rebirth of the clinic, xi.

${ }^{523}$ K. Waaijman, 'Waarom ik?' in: Jota 16 (1993), 46-56; K. Waaijman, Psalmen bij ziekte en genezing, Kampen $1989^{2}$.

524 Waaijman, Spirituality, 86-89.

525 Benner-Carson, Spiritual dimensions of nursing practice; Bradshaw, Lighting the lamp.

526 See the above mentioned studies of Fitchett, Van Leeuwen \& Cuseller, Leget, De Dijn, SayreAdams, Sulmasy and others. 
Secondly, over against the tendency in all cultures to isolate ill people, to banish them to a realm of solitariness, and to exploit their vulnerable situation, health care spirituality organizes relationships with family and neighbours, inspired by mercy and compassion. ${ }^{527}$ In health care spirituality, (re)integration in the social environment is part of the healing process.

Thirdly, over against modern medicine, which objectifies a patient as a 'case' and reduces him to his illness, health care spirituality tries to establish a human relationship between caregivers and caretakers. Patients need the attention and presence of nurses. Words that articulate their expectations are: contact, comfort, conversation, encouragement, and prayer. Research indicates, 'that the basic care activities that seem to form the essence of spiritual care are a nurse's presence, listening, respect.'. 528

Finally, the above mentioned integrations and connections can mediate the divine-human relationship. Verna Benner Carson mentions a number of interventions mediating God's healing presence: respectful listening, humility and solidarity, performing religious rituals, and so forth. ${ }^{529}$ On the basis of years of experience with cancer patients, Miriam Jacik described the same desirable attitude toward patients: entering into a relationship with them, sharing one's pain, listening and seriously responding to one's concerns, having the courage to be present to the other. ${ }^{530}$ If this attitude is incorporated in the professional attitude as a whole, the healing process mediates the divine-human relationship.

\section{Spirituality and Natural Sciences}

Robert John Russell developed a framework for the interdisciplinarity between theology and science, calling it a 'creative mutual interaction'. ${ }^{331}$ Within this 'interaction' he included spirituality, 'allowing for the possibility that it too could play a constructive heuristic role in the development of research science'. ${ }^{532} \mathrm{His}$

\footnotetext{
${ }_{527}$ R. Wuthrow, Acts of compassion: Caring for others and helping ourselves, Princeton 1991.

528 Van Leeuwen, Tiesinga, Post \& Jochemsen, 'Spiritual care', 883.

529 See 'Spirituality and the nursing practice', in: Benner-Carson, Spiritual dimensions of nursing practice, 164-175.

530 Ibid., 53-54.

531 R. Russell, 'Bodily resurrection, eschatology and scientific cosmology: The mutual interaction of Christian theology and science', in: Resurrection: Theological and scientific assessments (Ed. T. Peters e.a.), Grand Rapids (MI) 2002.

532 R. Russell, 'Natural sciences', in: The Blackwell companion to Christian spirituality (Ed. A. Holder), Malden-Oxford-Carlton 2005, 331; Idem, 'The contributions of natural sciences to the academic discipline of Christian spirituality', in: Exploring Christian spirituality (Ed. B. Lescher \& E. Liebert), 119-141.
} 
proposal is 'that Christian spirituality should now be understood as a part of the holistic epistemic network that includes the natural sciences, and that discourse and fertile exchange flow in a multitude of overlapping directions between all these disciplines'. ${ }^{533}$ Meanwhile, there is an exponentially growing wealth of literature in the interdisciplinary field of science and spirituality. 534

Disciplines. Cosmologies belong to the spiritual repertory of every indigenous spirituality: the primary interaction with nature, both theoretical and practical. In these repertories, there is no split between 'science' and 'spirituality'.

In modern natural sciences, a clearly defined framework of thinking and operating is at work: a separation between the subjective/inner world and the objective/outer world; the reduction of relationality to causality; the basic operations of quantifying and measuring; the absolute distinction between dead things and living beings.

At the margins of modern physics common ground between natural sciences and spirituality is beginning to emerge: ${ }^{535}$ in the search for the depth-structure of nature, the human search for meaning and values is co-determinative; ${ }^{536}$ the laws of physics are approximations of the fundamental laws of nature, confronting the researcher with the spiritual paradox: 'The eternal mystery of the world is its comprehensibility' (Albert Einstein); 537 spirituality and science are connected by the structure of the search process, based on the refusal to be bound by images or models, propelled solely by a passion for truth. ${ }^{538}$

In the field of spirituality and natural sciences, one may observe a constant stream of publications demonstrating a growing attention of researchers attempting to articulate a coherent perspective..$^{539}$

533 Russell, 'Natural sciences', 331.

534 See Russell, 'The contributions of the natural sciences', n. 15.

535 K. Waaijman, 'Raakvlakken tussen natuurwetenschap en mystiek', in: Wending 39 (1983) no.8, 501-508; M. Benevent, Entre science et spiritualité: L'indispensable renouveau, Nimes 1992; F. Capra \& D. Steindl-Rast, Belonging to the universe: Exploration on the frontiers of science and spirituality, San Francisco 1992; R. Sheldrake \& M. Fox, Natural grace: Dialogues on science and spirituality, London 1996.

536 R. Jones, Physics and metaphor, New York 1983.

537 A. Einstein, 'Physics and reality', in: Ideas and opinions, New York 1978, 285-315; T. Torrance, Divine and contingent order, Oxford 1981; J. Polkinghorne, The faith of a physicist: Reflections of a bottom-up thinker, Princeton (NJ) 1994.

538 F. Maas, 'De niets-ervaring als aanknopingspunt tussen mystiek en technische cultuur', in: Speling 33 (1981) no.4, 67-76. See K. Popper, Logik der Forschung, Tübingen 19766.

539 See particularly the studies of Robert John Russell in: Science and the spiritual quest: New essays by leading scientists (Ed. W. Richardson \& R. Russell), London-New York 2002; R. Russell, 'Spirituality and science', in: The new SCM dictionary of Christian spirituality, 55-61 with literature. 
Theories. Cosmologies providing the framework for the understanding of the nature of the cosmos can be mythic, spiritual, scientific, or a mixture of them.

Premodern cosmologies integrate spiritual and scientific aspects. One example: an old alchemist treatise is named Ta phusika kai ta mystika, encompassing 'natural science' and 'spirituality'. There is no split between the material and spiritual world, between form and matter, high and below, heaven and earth, quantity and quality, and so forth.

Modern cosmologies made a clear distinction between the material world (nature) and the realm of spirituality, thus eliminating spiritual insights and deep experiences from the scientific project in the Western world.

In postmodern science, some limits of this framework are highlightened. Quantum physics discovered that causality is not a universal law, there are also influences on distance (synchronicity); there are intrinsic links between the atomair level (the objective/outer world) and human perception (the subjective/inner world), some basic phenomena are seemingly contradictory (quantity/quality; waves/particles; the presence of spontaneity and unpredictable changes in subatomaire reality as signs of 'life' in seemingly dead matters); 'contraria sunt complementaria' (Niels Bohr). ${ }^{540}$

Developments in natural sciences, in the field of micro- and macrocosm, have urged scientists to change their framework. The consciousness of the irrationality of the split between scientists and mystics is growing. It is indeed a strange situation: mystics understand the roots not the branches, scientists understand the branches not the roots. ${ }^{541}$ From within scientists are becoming aware of the connectedness between matter and mind, exteriority and interiority, mechanism and organism, particles and waves, cosmogony and theology, visible and invisible, law and contingency, causality and synchronicity, dead material and living beings, and so forth. ${ }^{542}$ This idea of interconnectedness - a central element in cosmologies, unifying divergent aspects of the world - seems to be permeated by the idea of the sublime, which Kant supplemented with the idea of beauty, and by the experience of awe-inspiring nature, by later Romantic theorists associated with the holy.

\footnotetext{
540 See F. Capra, The Tao of physics: An exploration of the parallels between modern physics and eastern mysticism, Berkeley 1975; W. Pauli, Physik und Erkenntnis Theorie, BraunschweigWiesbaden 1984; Der Pauli-Jung-Dialog und seine Bedeutung für die moderne Wissenschaft (Ed. H. Atmanspacher e.a.), Berlin-Heidelberg-New York 1995; H. van Erkelens, Het spel van de wijsheid: Pauli, Jung en de menswording van God, Kampen 1995; R. Sheldrake, De wedergeboorte van de natuur, Amsterdam 1997; H. van Erkelens, Wolfgang Pauli und der Geist der Materie (Ed. Th. Arzt e.a. ), Würzburg 2002.

541 S. Toulmin, The return to cosmology: Postmodern science and theology of nature, Berkeley 1982.

542 Naturerklärung und Psyche (Ed. C. Jung \& W. Pauli), Zürich 1952; Sheldrake, De wedergeboorte van de natuur; A. Zajonc, Het licht zien: Het verbonden bestaan van licht en bewustzijn, Zeist 1996; H. Greaves, Boodschap van licht, Breda $1996^{3}$.
} 
Within the triangle science, ecology and spirituality the idea of connectedness seems to become more and more the point of gravity in a new scientific paradigm, inspired by mystical insights. ${ }^{543}$

Professions. In the field of tension between science and spirituality, some role profiles can be distinguished.

Firstly, the technician, applying science to the invention and production of tools, multiplying the powers of human senses and organs. Although technology, spiritually seen, in modern culture is ambiguous, ${ }^{544}$ the role of the technician as a spiritual model is, precisely for that reason, a challenge, ${ }^{545}$ particularly in the area of agriculture, transportation, communication, energy and reproduction of knowledge and art.

Secondly, the environmental defence rises up within the context of a protest movement against the detoriation of the ecosphere. This role has many faces: the combatant and liberator, ${ }^{546}$ the activist and politician (Greenpeace; the political movement of the Greens, NGO's).

Thirdly, the steward, trustee or conservator. In recent times Jewish-Christian traditions have been accused to be the cause of all detoriation of the ecosphere, giving human beings the role of an anthropocentric dominator, legitimated by the God given mandate over creation (Gen. 1-2). Reflecting on these accusations a redefinition of the human role in creation is developed. ${ }^{547}$

The increasing stream of exploratory studies seems to move into the integration of premodern (spiritual traditions), modern (technology) and postmodern (defence, combat, ecosophy) incentives for the development of adequate spiritual role-models in the area of science, technology and spirituality.

Words. As every discipline, natural sciences have their specific vocabulary: matter, measure, number, causality, relativity, particle, wave, energy, law, axiom,

${ }^{543} \mathrm{H}$. Walach, 'Reconciling spirituality and science in the twenty-first century: Elements for a world view incorporating spiritual and scientific insights', in: Studies in Spirituality 15 (2005), 283-308.

${ }^{544}$ M. Downey, 'Technology, impact on spirituality', in: The new dictionary of Catholic spirituality, Collegeville (MN) 1993, 958-959.

545 See R. Pirsig, Zen and the art of motorcycle maintenance, New York 1974; I. Gotz, Technology and the spirit, Westport 2001.

546 C. Merchant, Radical ecology: The search for a liveable world, New York 1992: A. Primavesi, From Apocalypse to Genesis: Ecology, feminism and Christianity, Wellwood 1991.

547 D. Hall, The steward: A biblical symbol come of age, Grand Rapids-New York 1990; A. Meyer \& J. Meyer, Earth keepers: Environmental perspectives on hunger, poverty and injustice, Scottdale (PA) 1991; M. Oelschlager, Caring for creation: An ecumenical approach to the environmental crisis, New Haven 1994. 
weight, quality, quantity, life, light, and so forth. In the field of spirituality and science, a lot of basic words are naming the reality in which and through which we live: world, cosmos, nature, eco-, environment, universe, whole, creation, physical world, material world etcetera. Although in dictionaries some of these words shortly are explained, sometimes with a series of links, till now no semantic research in this area has been performed.

Things. Things belong to the preferential area of natural sciences, searching insight in light years and subatomic life, in macrocosmos and microcosmos. Science is the way modern people are initiated into the world of things, going into unimaginable times, The Big Bang 13 billion years ago; into endless spaces of an expanding universe; into the invisible depths of the atomic particles and/or waves. This initiation gained by sharp distinctions (matter-mind, inner-outer etc.) brought modernity at the end of its journey in the world of quantum mechanics, the world of connectedness, synchronicity, relativity and complementarity. The different things and spheres of the world are mysteriously comprehensible because we presuppose them to be synchronic related and complementary. They are relatively independent: mind and matter, reality and dream, here and there, past and future. The divergent regions of being and the correspondent styles of cognition are not 'contraria' but 'complementaria'.

Art. World pictures are unifying images of the world. Premodern world pictures are predominantly mythic and spiritual. Particularly, indigenous spiritualities produce inspiring representations of the cosmos, facilitating for the participants an initiation in the divine-human world.

Modern world pictures were in the past predominantly mechanistic and fragmentized in particles. On behalf of the representations of the invisible processes, in the micro- and the macrocosm imageries of atoms, molecules, cells, solar systems and milky ways are developed. Meanwhile quantum physics changed the scientific world picture: from mechanistic and fragmentized representatives into interactive and organistic imageries.

Some convergence seems to be at work between science, spirituality and art. An example in the 1990s started the international project Art Meets Science and Spirituality in a Changing Economy. In the publication accompanying this project, ${ }^{548}$ scientists and artists are interviewed. Reflecting on these interviews and other literature, one may have the impression that there is some common ground between science, spirituality, and art.

548 Art meets science and spirituality in a changing economy (Ed. C. Tisdall et al.), 's Gravenhage 1990 (Conference Proceedings, Amsterdam 1990). 
From the perspectives of science: known is the tendency of scientists to look for a formula, explaining truly the deeper structures of nature, which is also beautiful and simple. This sense of beauty, simpleness, sublimity and awe-inspiring respect permeate representations of nature in the audio-visual world. ${ }^{549}$ Similarly scientific art figures in eco-spirituality. From the perspective of art: some modern artists reflect on 'scientific' attitudes, sometimes recognized by scientists. Mondriaan's paintings, for instance, are by the artist himself seen as the terminal point of a process of searching. Proceeding from concrete objects, he arrives at what he conceives to be their essential structure, a process of reduction to almost mathematical forms and primary colours. The drawings of Esscher, experimentations in reality models, are by some scientists seen as experiments-in-reality.

At this moment we observe a growing stream of explorative publications in the field of science, spirituality, and art, in a phase of fine twining 550 inspired by deep ecology, ${ }^{551}$ waiting for groundbreaking studies.

Texts. In premodern times, the performance of hymns and narratives on the cosmos belonged intrinsically to the 'science' of nature and creation. All cultures have their 'myths' to initiate their participants into the spirituality of their cosmos. ${ }^{52}$ In these 'myths' we have to distinguish between the creation of the world, centred around the capital of a culture, and the creation of the human being by a personal God. ${ }^{553}$ The history of spirituality shows a rich tradition of texts initiating the performers into the divine-human relationship mediated by nature: the psalms of creation, the Canticle of Brother Sun, the visions of Hildegard von Bingen, and Teilhard de Chardin's Hymn of the Universe. ${ }^{54}$ Many contemporary writers and poets expressed the spiritual significance of nature. ${ }^{555}$

\footnotetext{
549 The world treasury of physics, astronomy and math (Ed. T. Ferris), Boston 1991.

550 Sheldrake \& Fox, Natural grace.

551 A. Booth, Learning to walk in beauty: Critical comparisons in ecophilosophy focussing on bioregionalism, deep ecology, ecological feminism and native American ecological consciousness, Madison 1992.

552 For the literature of the Near East in biblical times see C. Westerman, Genesis I/1, Neukirchen 1983³, 104-191. See also T. Hiebert, The Yahwist's landscape: Nature and religion in early Israel, New York 1996.

553 R. Albertz, Persönliche Frommigkeit und offizielle Religion, Stuttgart 1978.

554 O. Steggink, 'Natuurbeleving, natuurlijk milieu en mystiek', in: Encyclopedie van de mystiek (Ed. J. Baers et al.), 302-310.

555 D. Burton-Christie, 'A feeling for the natural world: Spirituality and the appeal to the heart in contemporary nature writing', in: Continuum 2 (1993), 229-252; Idem, 'Mapping the sacred landscape: Spirituality and the contemporary literature of nature', in: Horizons 21 (1994), $22-$ 47; Idem, 'Nature', in: The Blackwell companion to Christian spirituality, 478-495; C. Raymo, Natural prayers, St. Paul (MN) 1999.
} 
Not only writers and poets produce texts which express the spirituality of nature, also scientists themselves have articulated their spiritual experiences in their encounter with the mystery of nature. ${ }^{556}$ The question is however, whether this literature belongs to the text corpus of scientists.

Histories. The basic story of natural sciences is evolution. Paradigm is modern biology, interpreting the evolution of life on earth as the ongoing result of random genetic and environmental variations together with natural selection'. 557 This paradigm is expanded to the interpretation of the universe as an evolution, starting with the Big Bang. Evolution involves suffering, death and extinction, without which the complexity of life on earth would not have occurred. Evolution did not only include genetic mutation on the level of quantum physics, but also the gradual growth of consciousness and discernment, which on its turn influenced the brain. 558

Does this evolutionary 'history' of scientists exclude God's existence, his presence and activity? Some say: 'Yes'. Others doubt. Some presume an 'intelligent design'. From the viewpoint of spirituality, God could give from within a sense of directionality to the evolution of life.

There is a functional purpose (teleonomy) in the way species are adapted to their environment, but it is an evolved purpose produced by a recipe (the genetic code), not by a blueprint, and it requires no external 'agent' (pace the proponents of 'intelligent design'). This more modest, but nevertheless genuine, sense of 'purpose' opens our spiritual experience to God as creating 'from within' the dynamic history of life on earth, working in and through its ever-changing pathways, responding continually to its varying contours with the eschatological future in mind. This dynamic view of God's purposeful action in evolution resonates with our lived spiritual experience of God's continuing and purpose-filled influence in our lives. 599

Processes. The universe is like a text to be deciphered. This deciphering starts with the 'reading' of our environment from within our own situation, as the well-known ecosopher Arne Naess states. ${ }^{560}$ This hermeneutical process is motivated by 'a deep yes to nature. What do we say yes to? Very difficult to find out - there is a deep unconditionality, but at the same time there is a kind of regret,

\footnotetext{
556 See for instance Capra, The Tao of physics; W. Heisenberg, Physics and beyond, New York 1972; A. Pais, 'Subtle is the Lord ... '? The science and the life of Albert Einstein, Oxford 1982.

557 Russell, 'Spirituality and science', 57.

558 Neuroscience and the person: Scientific perspectives on divine action (Ed. R. Russell, N. Murphy et al.), Berkeley 1999.

559 Russell, 'Natural sciences', 337.

560 A. Naess, Ecology, community and lifestyle, New York 1991.
} 
sorrow or displeasure' ${ }^{561}$ It is from within the lived experience that a process of transformation unfolds itself, including ethical behaviour: 'Ethic follows how we experience the world'. ${ }^{562}$

This process of transformation is a voyage of discovery. Matthew Fox sees four paths. ${ }^{563}$ The via positiva is the first path: in awe and respect enjoy the Mystery of nature and of all beings. The second path is the via negativa: in silence and emptiness letting go and letting be. The third path is the via creativa: in generativity and imaginative out-put co-creating with God. The fourth path is via transformativa: in celebration coming together to praise God and giving thanks for the gift of being and being together. ${ }^{564}$

Relationships. 'Our most basic spiritual interaction with nature (...) is the experience of "being in the world", of the sheer, surprising and compelling taste and touch of the natural world around us and within us'. In spirituality, such is understood as 'union with nature-as-community (a relational spirituality)'. ${ }^{565}$ This union with nature as community is the midst in which (medium in quo) human beings may meet God the Creator and enter the 'mystical union with the divine source of nature'. 566

Connectedness, as basic presupposition, seems to bridge modern scientific insights and spirituality. This basic conviction is sustained by ecosophy, deep ecology, and ecospirituality, expressing their concern with the biosphere and the ecosystems, in the imagery of family, place, home, body, partnership and other symbols, directing and regulating the general outlook of a scientific generation. ${ }^{567}$

One of the most challenging theories of such a spiritual cosmology of things, united in a deep connectedness, may be the ars coniecturalis of Nicolas of Cusa. Every thing can be seen as the centre, unfolding in a specific manner the whole, challenging the human mind to see this unfolding of its universal meaning and to gather together (coniectura) the richness of the whole in this unique thing. ${ }^{568}$ This vision seems in complete accordance with the quantum systems as far as they are seen as

\footnotetext{
561 Ibid., 20.

562 Ibidem.

563 M. Fox, Creation spirituality, San Francisco 1991.

564 'Creation-centred spirituality', in: The Way 29 (1989, special issue) no.1; C. Cummings, Ecospirituality: Toward a reverent life, Mahwah (NJ) 1991.

565 Russell, 'Spirituality and science', 55.

566 Ibidem.

567 Th. Berry, Befriending the earth, Mystic 1991; J. McDaniel, Earth, sky, gods and mortals: Developing an ecological spirituality, Mystic 1990; S. Mc Fague, The body of God: An ecological theology, Minneapolis 1993; R. Taylor, The search for a sacred place: Essays toward a spirituality of nature, Ann Arbor (MI) 1992; S. Jung, We are home: A spirituality of the environment, New York 1993.

568 I. Bocken, Waarheid en interpretatie: Perspectieven op het conjecturele denken van Nicolaus Cusanus 1401-1464, Maastricht 2002; Idem, De kunst van het verzamelen, Budel 2004.
} 
'non local' and hence 'non separable', suggesting a 'wholeness' and 'unity' to nature and offering 'a powerful metaphor for the spiritual experience of intrinsic relationality within the divine life and of the unity of creation'. ${ }^{569}$ All creatures are sharing the same quantum systems and the biochemistry of our genes, "leading us to a spirituality of community with nature'. ${ }^{570}$ This implies the notion of 'responsibility'. ${ }^{571}$

\section{CONCLUSIONS}

From the 1980s on I followed the study of spirituality in various disciplines. ${ }^{572}$ From 2000 on making a last extensive 'round', I was again - and even more than before - impressed by the breadth and depth of the scholarly research in the field of spirituality. The result of this study is meant to map out, in an encyclopedic way, what happened in twelve disciplines. I described the scholarly efforts in these disciplines, exploring the ten encyclopedic dimensions. By doing so, some points of contact between the disciplines or at least some comparability came to the fore. Hopefully, this systematic procedure brings some centripetality into the chaotic centrifugality which seems to characterize the study of spirituality. The field of interdisciplinarity came a little bit more to the fore - hopefully.

In the closing reflections of this article I try to discover possible interfaces between the twelve disciplines. To that end we will look through each of the ten encyclopedic dimensions, and reflect on the role of the various disciplines.

Disciplines. Up to now the study of spirituality is a multi-disciplinary enterprise, the challenge is that it will become a interdisciplinary network. How to imagine this interdisciplinarity? As a contribution to the ongoing discussion on this point, I would propose the following configuration.

To start with, spirituality can be situated within the quadrangle theology, religious studies, philosophy and anthropology. In this quadrangle the breadth and the depth of the phenomenon is guaranteed. Theology and anthropology reflect the divine-human relationship. Religious studies and anthropology reflect the broad variety of spiritual forms, encompassing both schools of spirituality and primordial spirituality (indigenous, secular, and lay spirituality). Philosophy and (fundamental) theology are equipped to deal with the epistemological questions, needed for a further interdisciplinary development.

\footnotetext{
569 Russell, 'Spirituality and science', 57.

570 Ibid., 58.

571 W. van Nunen, De intrinsieke waarde van de natuur als ethisch dilemma, Tilburg 1993.

572 See O. Steggink \& K. Waaijman, Spiritualiteit en mystiek: 1. Inleiding, Nijmegen 1985, 6778; Waaijman, Spirituality, 392-424.
} 
From another perspective theology, religious studies, history and literary studies form a quadrangle. They develop the critical tools to describe, interpret and understand the texts and histories of spirituality.

Anthropology is linked with the cluster of social sciences, two of them being more general (psychology, sociology), three of them being more specific (pedagogy, management sciences and medicine). They unfold, together, the human dimension of spirituality, counterpart of the Divine dimension, which is the focus of spiritual theology.

A couple on its own seems to be spiritual theology and natural sciences. At this stage of reflection, I do not see what other connections this couple has.

This is a first draft expressing the first configuration of interdisciplinarity in the field of spirituality.

Table 1

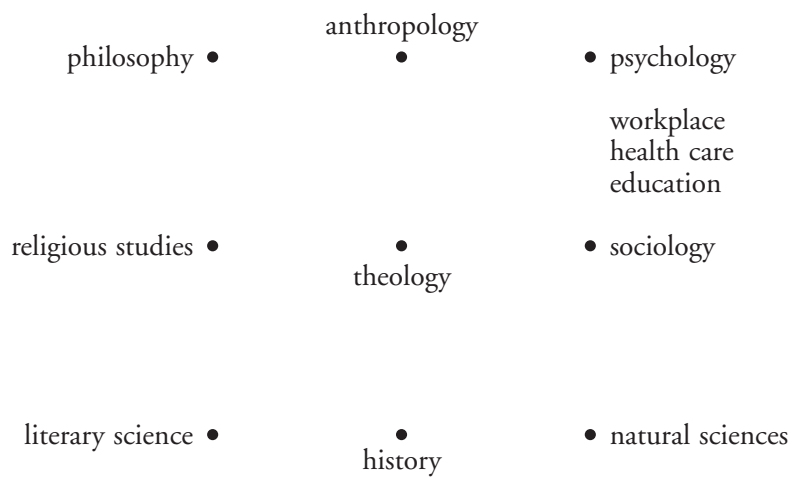

Reflecting on this configuration, we may observe the central role of theology, that is to say: theology as it is organized in most of the actual faculties of theology, being an interdisciplinary network, containing systematic disciplines (ethics, dogmatics, connected with philosophy), religious sciences (descriptive and/or philosophical), literary and historical disciplines (church history, exegesis), and social sciences (anthropology, psychology and sociology of religion). Within such a consortium of disciplines, called 'theology', spirituality has its adequate place, from where it can unfold its interdisciplinary relationships within the broader field of academic disciplines. In this set up, theology has a centripetal force: a circle of knowledge as a circle of learning, a pedagogical area that exists in a teaching and learning situation in which the teaching and learning are facilitated by the pursuit of scientific, scholarly inquiry. ${ }^{573}$

${ }^{573}$ E. Farley, The fragility of knowledge: Theological education in the church and the university, Philadelphia 1988. 
This is a first formal draft of the interdisciplinary network of spirituality. Our further explorations - following the encyclopedic dimensions - will give this network more content, color and relief. Then also the tensions will become visible.

Theories. According to the philosopher Theo de Boer, one of the four pillars of scholarly research is inspiration: what animates and orientates human thought? ${ }^{374}$ Imagination, reasoning, and experience are not enough. A truth-loving mind is not content with the so called 'reality' or 'horizons' or 'categories'. The ultimate question is: what is this really? To what is this leading? What gives direction to these perceptions, constructions and argumentations:575

'Inspiration' belongs to the central concern of theology and philosophy. We have seen how important thinkers like Lonergan, Rahner, Buber, Levinas and others are for the orientation of spirituality. On this point, philosophy (metaphysics and philosophy of religion) and theology (fundamental and systematic theology) form the main axis within the interdisciplinary network of spirituality.

Table 2

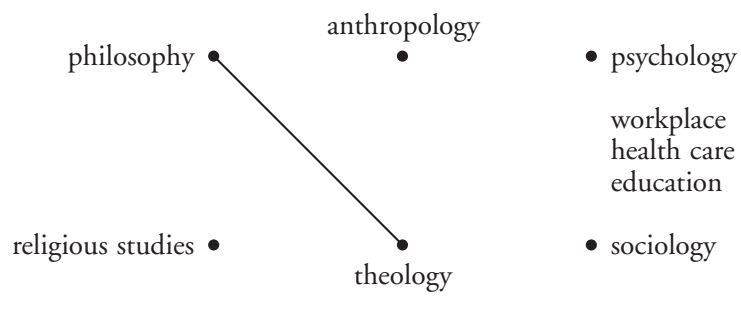

literary science $\bullet \quad \stackrel{\bullet}{\bullet} \quad \bullet$ natural sciences

In our view, the other disciplines in the field of spirituality need a strong philosophical-theological 'orientation', not a rigid system of truths and values! It meant a set of fundamental questions, inspiring the whole network: what does this really mean? What is the ultimate concern? How is the divine-human relationship articulated and what is its orientation? These fundamental questions are important for literary-historical research and for religious studies. They are intrinsically connected with the main 'sources' in these fields of research. After all, as sources of spirituality they embody inspiration and direction. In them the Mystery is always present.

\footnotetext{
574 Th. de Boer, De vier zuilen van de filosofie, Amsterdam 1997.

575 Ibid., 8-9.
} 
Problematic in this respect are the 'social sciences'. Here the mind of the scientist is 'conceptualizing' the very essence of spirituality mostly by constructing a split between religion-with-God and spirituality-without-God. Spirituality is conceived as an intrapsychic dynamism, as self-experience, self-transcendence, well-being, and inner balance. In this way psychology, sociology, pedagogy, management sciences and medicine reduce spirituality to human development. Interesting is however, that anthropologists in their fieldwork discovered the divine in and through the human! These anthropological insights in spirituality can become very important for the interdisciplinary network of spirituality, mediating between theology-philosophy and social studies.

Professions. Traditionally spiritual professions are located in the area of theology: ministry, spiritual direction, formation, retreat, conferences, etc. They were connected with church activities and services in religious life. Meanwhile, new forms of spiritual care can be observed. In the world of spirituality and education, the roles of the teacher and the child are more and more considered from the perspective of spirituality. The same goes for health care: professional nursing has its spiritual component and is attentive for the spirituality of the patient. Workplace spirituality asks for spiritual leadership and a spiritual attitude of the workers. Sociology and psychology have developed their own areas of spiritual practice and therapy. In the world of natural sciences, the representatives of the ecospirituality are clearly present: the combatants and liberators, the activists and conservators, the stewards and trustees. Spiritual anthropologists offer their services in processes of inculturation and evangelization. The science of religion delivers spiritual practioners for the interreligious dialogue.

New in this field of spiritual professions is not only the broad spectrum of workplaces in secular settings, outside the traditional schools of spirituality, but also the structure of these professions. The last decades both the traditional ministries and the new forms of spiritual care are orientated on the psycho-social competencies. The content (texts and histories) has become less dominant.

Modern theology, especially practical theology, is characterized by a lively interdisciplinarity between all kinds of ministries, sevices and professions, as described above.

From a viewpoint of spirituality, these practices and professions should be orientated by 'mystagogy', focused on consciousness: the awareness to be in relationship with the Divine, the main 'actor' in processes of spiritual transformation. Practices and professions in the area of social work, education, work and management, health care, environmental and peace work, industry and creativity are innerly waiting on moments of spiritual awareness. In a sense, they are 
Table 3

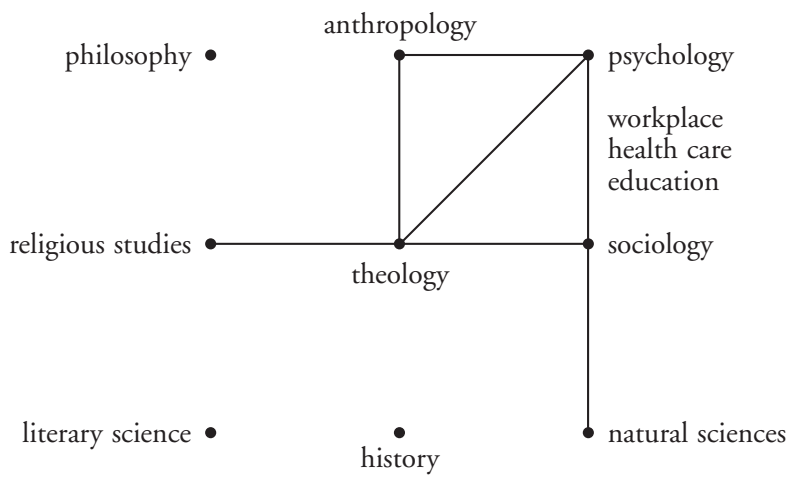

all forms of spiritual direction, oriented by discernment. Therefore, also in this area of practices and professions the basis of spirituality - spiritual accompaniment, discernment, mystagogy - should be garanteed, within the context of secular and human practices and professions.

Words. If we look in the dictionaries of the last decades, we may perceive a shift in spiritual language. New words came in, old words disappeared. ${ }^{576}$ At the one hand there is the traditional vocabulary: spirit, soul, God, divine, human, prayer, etc. At the other hand new words from the 'secular' spirituality are introduced: work, health, learning, care, child, teacher, management, healing, etc. Sometimes it seems as if there are two languages: a language taken from religious texts and

Table 4

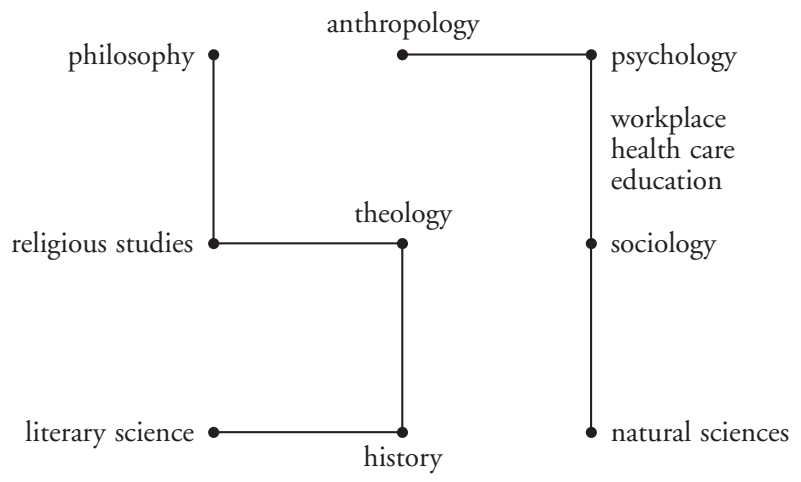

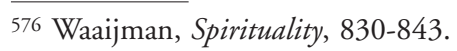


histories, from theology and philosophy, and a language spoken in modern culture, social and natural sciences, in the workplace, in the schools and hospitals. It is evident, that 'words' in general and 'key-words' in particular are important for the interdisciplinarity of spirituality. The mere word 'spirituality', rootmetaphor of the discipline, demands constantly our attention. The same goes for 'mysticism'. It needs an encyclopedia in which key words are understood from an interdisciplinary perspective. It is self-evident that the literary-exegetical-historical approach should be the leading authority in this area. Of course, the other disciplines have their own dictionaries, each of them treating their own vocabulary. But from an interdisciplinary point of view, the literary-exegeticalhistorical approach should provide the adequate methodology.

Things. The 'material culture' includes two dimensions. First of all, the materiality in which spirituality expresses itself, in which it 'incarnates' itself. This materiality is evoked by words like: body, flesh, brains, atoms, molecules, air, light, breath, weight, and so on. This materiality is the world of natural sciences, focused on the world that surrounds us, hosts us, and forms us. The insights of spiritual theology and philosophy paved the way for this spiritual understanding, passing the dualism of spirit-matter. The writings of Teilhard de Chardin were on this point groundbreaking.

At the same time, materiality is the concrete context in which spirituality is performed. Michel de Certeau taught us that the social-cultural context, including the psycho-somatic patterns, is the language in which spirituality expresses itself. The material culture is a spiritual culture, a layered phenomenon, unfolding itself in synchronic and diachronic dimensions.

From an interdisciplinary point of view, the centers of gravity are psychology, sociology, natural sciences (for the synchronicity) and literary-history sciences (for the diachronicity).

Table 5

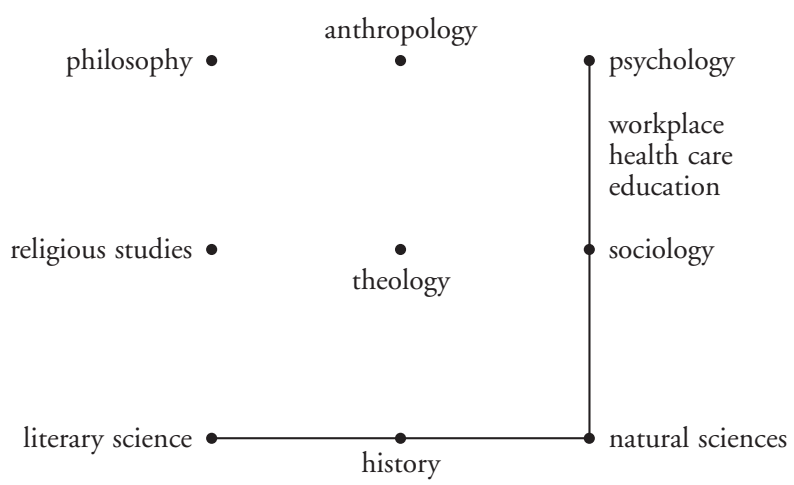


The other disciplines are not excluded. On the contrary, connected with the more 'material' disciplines, they become permeated by the 'incarnational' concreteness of spirituality, thus being capable, on a theoretical level, to avoid the dualism spirit-matter.

Images. Within the interdisciplinary network, the dimension of art, images and symbols seems to have two centers of gravity. The first center may be the speculative attention given to artistic phenomena by spiritual theology and philosophy. The second center may be the history of art and the literary science, documenting, analysing and interpreting images and symbols from a spiritual point of view. Both are complementary.

As we have seen, the last decades philosophy and theology made a shift towards concreteness. They consider art as it actually ís, as a spiritual phenomenon. The same shift, in the other direction, can be observed in the area of literary-historical research: the interest in spirituality is growing.

Table 6

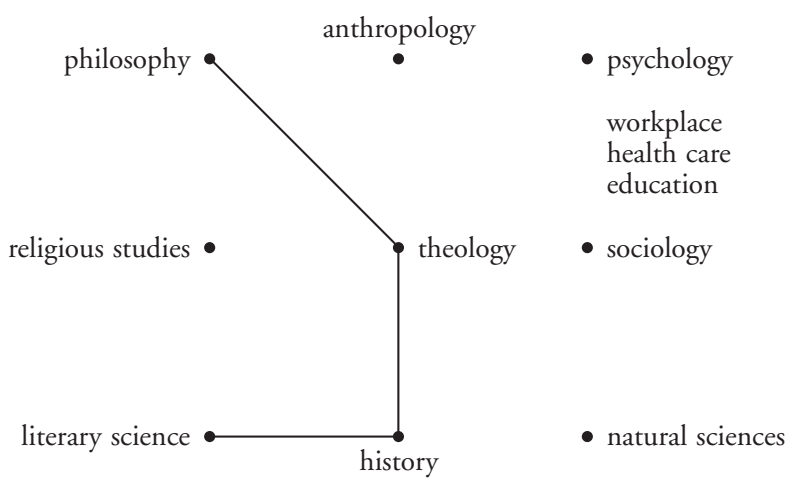

If our observations are true, the interdisciplinary network has a strong core, in which documentation and hermeneutics, description and interpretation are connected. This core can be an important inspiration for the other spiritual disciplines, being in themselves already sensitive for the area of art, images, and symbols. Especially psychological insights in art and creativity can become very fruitful for the study of spirituality. The processual approach to art - beyond closed rationalistic structures - may give entrance to symbolic objects as spiritual programs.

Texts. Within the interdisciplinary network of spirituality one may distinguish two language games, each of them having its own source. 
The first one is traditional: ritual texts, religious rules, prayers and biographies, sacred texts and spiritual writings. In the center of these traditional texts is the literary science, focusing on general questions about linguistics and hermeneutics and on specific techniques as text editions, reception, history, knowledge of genre and setting, interpretation, etc. Within theology this literary skill is performed by exegesis, materially concentrated on biblical literature, but formally connected with the modern science of linguistics and literature.

Anthropologists register oral traditions of indigenous spirituality and develop hermeneutical strategies to understand them.

The second language game is produced by social sciences. By interviews, autobiographical writings, questionnaires, and other techniques contemporary spiritual language is constructed and analysed. Also the language of natural science can be considered as a modern text.

From an interdisciplinary point of view, the study of spirituality is exposed to two text corpora: traditional texts, with their own hermeneutical traditions, and contemporary texts, analysed with modern means of interpretation.

Table 7

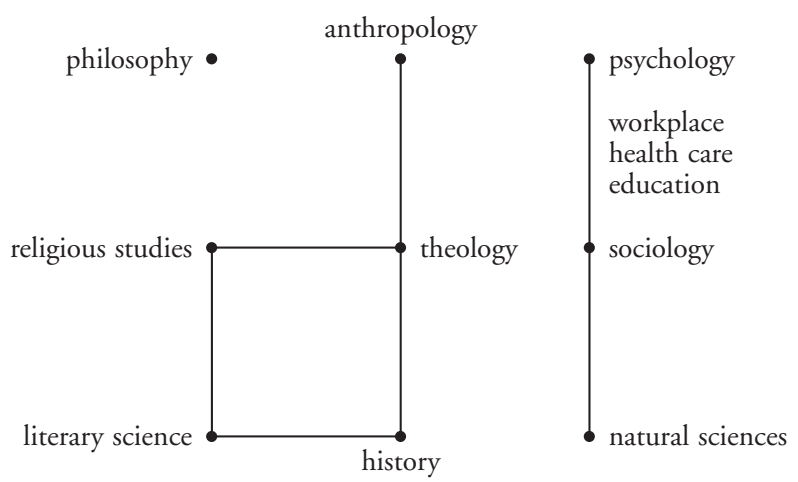

The core question is: how to connect these two language games? In my view the axis theology-philosophy is equipped to develop hermeneutical strategies, which can bridge the gap.

Histories. The dimension of spiritual 'histories' encompasses a wide range of data: from the stories about the universe to the L'histoire d'une âme, from socio-political facts to the descriptions of spiritual exercises, from the past to the present.

Histories (chronicles, witnesses, vitae, documents etc.) are first of all the object of the historical sciences, included the historical science as practiced in theology, being particularly equipped for the history of spirituality. Included is also the science of religions, in so far as it presents the various forms of spirituality. 
Within the interdisciplinary network of spirituality, the triangle of historical sciences, theology and religious studies seems to be the core.

Table 8

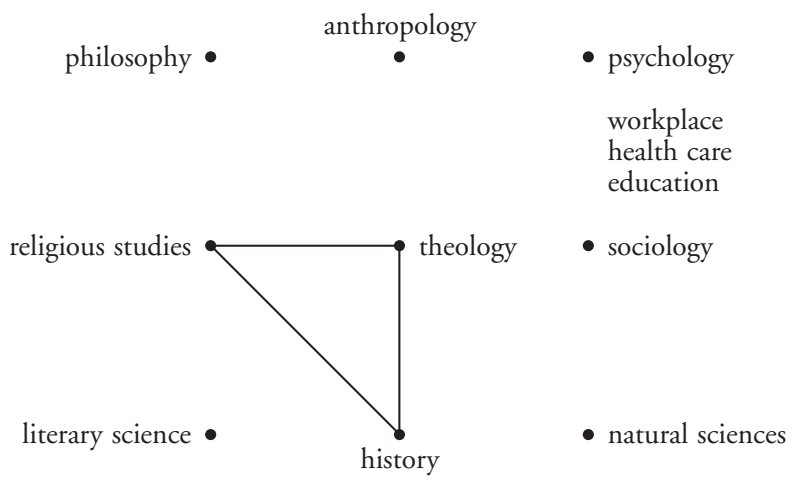

One of the main interdisciplinary challenges of the historical sciences is to integrate the material culture in the history of spirituality because the traditional historiography was too 'spiritual'. Another challenge is to integrate the 'stories' of the social sciences in the history of spirituality. The biographical data of these sciences are more 'secular', telling about the spirituality of 'laypeople' in schools, hospitals, and the workplace. An important challenge is also the integration of anthropological data, being mostly the oral traditions of indigenous spirituality. Finally, the natural sciences have broadened the history in the all encompassing 'history' of evolution, which spiritual natural sciences understand as the hidden and non-interventional presence of God. All these challenges mark the central role of history in the study of spirituality. A rich production of monographies, overviews and encyclopedic tools demonstrates the fertility of this discipline. Moreover, this discipline is open for theoretical questions on almost all aspects of the historical approach: the deeper drive of history, the tension between modernity and postmodernity, the problem of the historicity of spirituality, and so forth.

Processes. From the 1960s spirituality has become 'psychological'. The category 'experience' became more and more central. This was a danger because this centrality of experience overemphasized the human pole in the divine-humanrelationship. It is also a challenge, because the psychological attention strengthened the insight in the processual dimension of spirituality. From another perspective, sociology (of religion) brought the embeddedness of spirituality in social processes to the fore. 
It is not strange, that the center of gravity regarding spiritual processes can be found in the triangle psychology, sociology, and theology (practical theology, empirical theology, psychology and sociology of religion).

Table 9

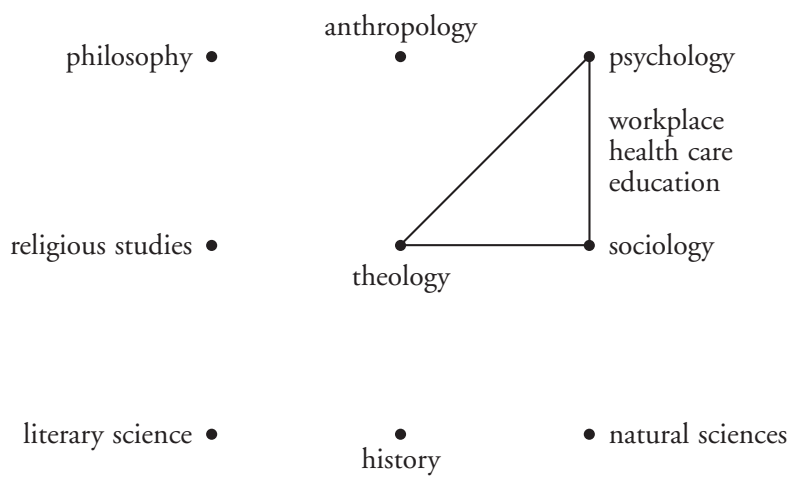

This triangle includes the spiritual processes in health care spirituality, workplace spirituality, and education spirituality.

Spiritual processes are a focal point within the whole of spirituality, both processes on the level of one's personal life and processes on the level of social life.

This attention for the processual dimension of spirituality, the intrinsic orientation of the other dimensions (the content, the contextuality etc.), does not exclude the literary-historical dimension. On the contrary, it will sharpen our mind for the processual dimension of mystical texts, (auto)biographies, rituals, and even rules. These literary-historical studies on spiritual processes may help us to see the 'divine' aspect in these processes of transformation.

The attention for the processual dimension of spirituality includes a strong relationship with the theoretical dimension as practiced in theology and philosophy, particulary in the area of hermeneutics.

Relationships. Relationality is a basic category in spirituality. It plays its role on different levels.

Firstly, on a personal level: the somatic, psychological, social and spiritual dimensions are interrelated. This we learned from health care spirituality (the holistic approach), from education spirituality (the whole child) and from workplace spirituality (a learning community).

Secondly, spiritual sociology taught us that 'community' (socius) is an essential aspect of spirituality, including commitment, service and ministry. Spiritual anthropology affirms this aspect. 
Thirdly, over against modern science, dominated by the mechanistic worldview of Newton - the world as a closed, causal order containing isolated 'things' - the quantum physics perceives the universe as an open system in which 'relationship' is the central category. Things are perceived in an open timespace, characterized by synchronicity, relationality and complementarity.

All these levels of connectedness 'incarnate' the divine-human-relationship, being the core of spirituality.

From an interdisciplinary point of view the center of gravity may be the area of anthropology, psychology, sociology, and social sciences.

Table 10

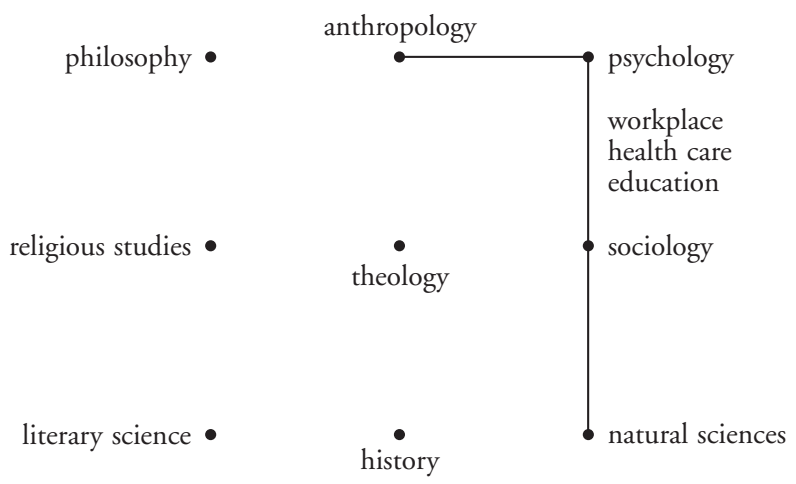

These four disciplines seem to develop the notion of 'relationality' as their core category. But their interdisciplinarity on this point is rather weak. One of the reasons of this weakness is, that the very notion 'relationship' is not critically reflected. Sometimes it seems to be identical with interconnectness or holism. Maybe, theology and philosophy can mediate between these disciplines to clear up this important category of 'relationship', essential for the understanding of the intrapsychic, interhuman, intracosmic and divine-human relationship.

The study of spirituality will profit by a growing sensitivity for the dimension of relationality. Relationality is the inner dynamic of all processes of divinehuman transformation. This understanding will place the phenomenon of spirituality, as presented in texts and histories, in a new perspective. 